\title{
Field of Intimacy:
}

Explorations of interiority within the landscape. 
Field of Intimacy:

Explorations of interiority within the landscape.

$$
\begin{gathered}
\text { By } \\
\text { Michelle Hall }
\end{gathered}
$$

A 120 point thesis

submitted to the Victoria University of Wellington in fulfilment of the requirements for the degree of

Masters of Interior Architecture

Victoria University of Wellington

18th February 2014 
I would not have been able to complete this Masters Research Thesis without the help and support of so many people, a list that would be impossible to write out, but there are a few special mentions I would like to make.

Firstly, to my Mum and Dad - Bronwyn and John - for coaching and consoling me through the stresses and freak-outs, helping me find clarity in my thoughts and expression, editing my work, and mostly, for always having the confidence and belief in me, that I can find clarity in my thoughts and expression, editing my work, and mostly, for always having the con
do whatever I put my mind to and pushing me to do just that.

To my partner Matt, for always being there for me through the difficult and confusing moments, for being my sounding board, for brightening up my days, for your constant, unwavering support and belief in me and my abilities, and for being there at the end of every day, no matter how late it is.

To my Grandparents Nannie and Da, for being so supportive and full of belief, passion and excitement about what I do. Also for $m y$ sisters, Kim and Anita, for having the confidence and belief in me when I find it wavering.

To my supervisors, Peter Connolly and Penny Allan, for guiding me through a foreign process and project, and helping me to find clarity in moments of pressure and confusion. You have both helped to push me through a project which would have been impossible without your guidance and knowledge, particularly relating to landscape.

To Regan, Sigourney and Sarah, for being there again in constant unwavering support, to bounce ideas off and to critique my work Without you as close friends I wouldn't have made it through the year unscarred. You have all helped me in different ways to see the potential and progress in this research.

To my thesis group, Amy, Matt, Vinnie, Jordan, Kristyn, Jess, Myren, Aliesha, you all helped me in different ways to understand what it was I was trying to do, brought laughter to studio and critiques, and let me be a part of the little landscape crew that was our group. And lastly, to Andrew Charleson, Nicci Wood, Geoff Ward, John Duder, Richard Keightley, Mark Essex, Llewellyn Lusty, Bill Arnold and Avon MacDonald from Wellington City Council Archives - thank you all for your advice, guidance and knowledge alongside this research. 
"Just in front of me, water appeared from out of the darkness.

Water! ... An immense body of water! ... And what water! ... Black, stagnant, so perfectly smooth that not a ripple, not a bubble, marred its surface. No spring, no source. It had been there for thousands of years and remained there, caught unawares by the rock spread out in a single, impassive sheet...."

Gaston Bachelard; The Poetics of Space (1964) 
Interior Architecture cannot be bound by the confines of a building, it is not the catalyst of architectural intervention, in fact we can have interior experiences within the landscape. As a discipline Interior Architecture tends to be quite insular, struggling to connect to the exterior context of a design, whereas landscape architecture tends to be so involved with the context at the large scale, that the finer details and experiences of space can be lost. Generally, engineered systems tend to be internalized and designed without regard for the social. There is an interesting connection between landscape and interior architecture, with landscapes being able to generate their own sense of interiority.

I have defined "existential intimacy" to describe the haptic bodily experience of a space through which one gains an understanding of something bigger than themselves (whether it be a system, process, or just being more aware and connected with their direct surroundings). This research explores what happens when notions of "existential intimacy" are applied within a landscape. Water is used as an important device for establishing existential intimacy enhancing the ability to engage with larger systems.

By applying existential intimacy to the Wellington context of Mount Victoria and engaging with stormwater systems in the city, a field of int a with a focus on existential intimacy, an expansiveness across scales is created, meaning that the design cannot lose
is forced to engage with both, to create spaces which are both functional (in an engineered sense) and experiential. 
2.1 Existential intimacy 2.1.1 Spatial Example 2.2 Existential Intimacy and the Senses 2.3 Existential intimacy and Water

2.3.1 Spatial Examples

2.4 Affordances, Assemblage Thinking and Existential Intimacy

2.5 Representing Existential Intimacy

2.6 Existential Intimacy, Interior, Landscape and Engineered Infrastructure

25

25

31

33

37

43

53

2.6.1 Spatial Examples 
3.1.1 Stormwater Issues in Wellington

3.1.2 Flooding versus Water Quality

3.1.3 Newtown Catchment and Mount Victoria

3.1.4 Mount Victoria and the Green Belt

3.2 Design Objectives

3.3 Merhodology

3.3.1 Landscape / Interior Interface

3.3.2 Engineering

3.3.3 Preoccupations

3.4 Design Iteration

3.4.1 Overall Context

3.4.2 The Cistern - Abandoned Quarry 
4.0 Discussion

5.0 Conclusion

6.0 List of Figures

7.0 Bibliography

8.0 Appendices

8.1 Inspiring Spaces

8.2 Design Development

8.3 Engineering Calculations 
1.0 Background

Over the past 5 years my university career has been based in Interior Architecture. During this time I have come to find that there is a huge misconception both with the general public and also among other creative design disciplines as to what Interior "Architects" (or Spatial Designers) actually do. With most assuming that all I was learning was how to deal with soff furnishing within spaces. I became frustrated with this incomprehension and as a result began to crave the challenge of pushing the boundaries of interior architecture in an attempt to broaden the understanding of what it actually is.

To me interior architecture cannot solely be defined by the bounds of a building; it is not the catalyst of architectural intervention but rather the spaces in between. Interior architecture is much more about designing the intense heightened spatial experiences we have whether they are inside a building or out in the landscape.

As Charles Rice describes in Bourgeois Inhabitations: Theory and the Historical Emergence of the Interior, the "concept of the interior, along with a professional practice of interior decoration emerged historically from the beginning of the nineteenth century.... [with] the interior [considered] as a condition 'additional' and 'consciously distinct from architecture', creating 'its own professional identity', and $\ldots$ an antagonistic relationship with the profession of architecture.". The meaning of the term interior has evolved "to mean both a space and a representation of a space", with interior being "caught between being both a part of architecture, at the same time as it exists apart from architecture". "The work of Elizabeth Grosz aligns more with the approach and definition I will be working towards, with

"the body of the inhabiting subject [being seen] as a means of exploring the way space gathers around the surface of the body, 


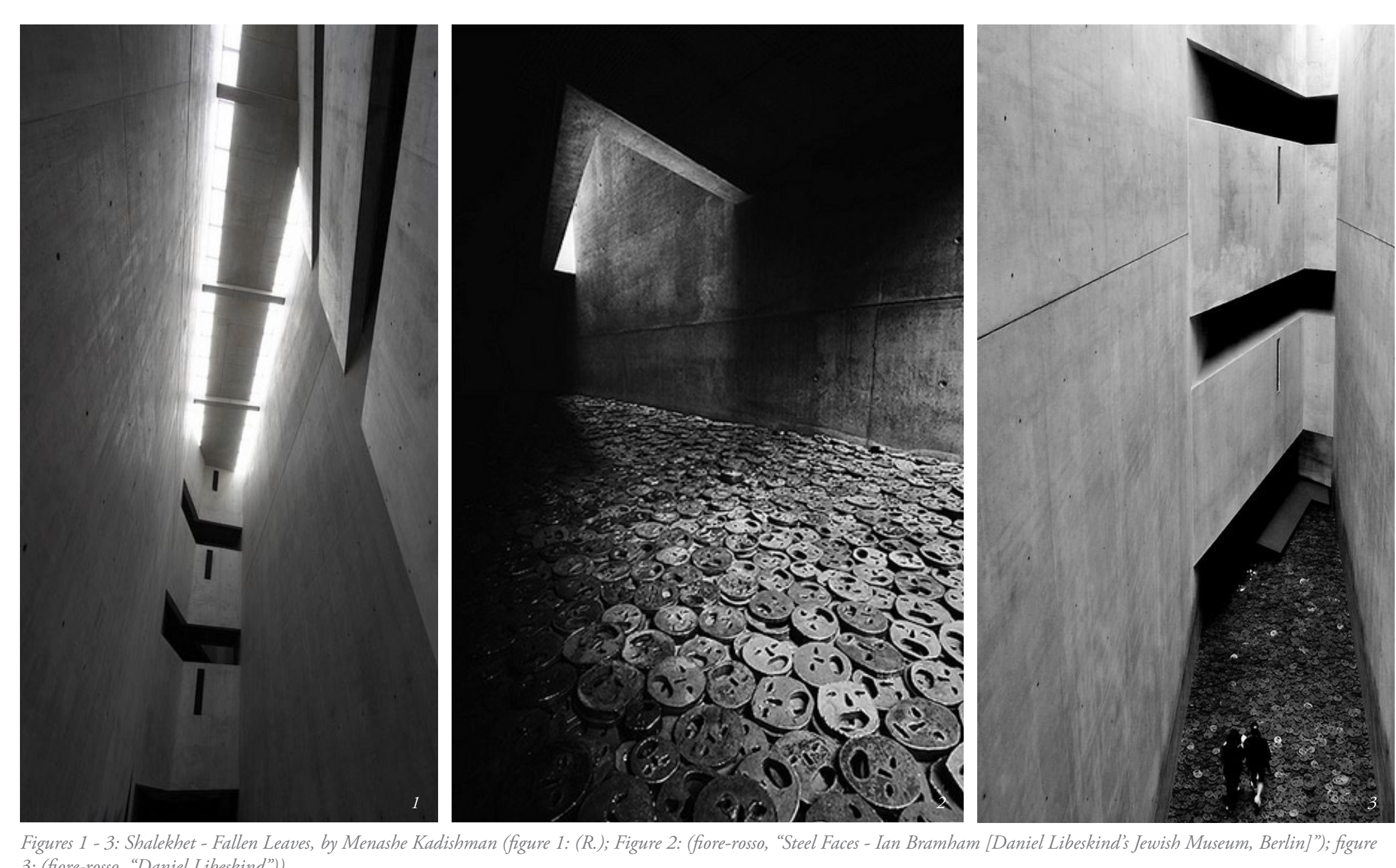

instead of treating space as a vessel with a fixed and fixing function in identity formation". ${ }^{3}$

This definition allows for a blurring of boundaries and thresholds, and starts to open up the idea that "the interior is only a selected exterior, and the exterior is a projected interior" and that the relations between interiors are "experienced as conceptual rather than as spatial entities". 4

When thinking of the spatial experiences that align these concepts of what interior can be, I began to realise that over the past few years of study I have become fascinated with a concept I think of as spatial intimacy.

The first experience I had of a space which had this sort of effect was in the spatial installation "Shalekhet - Fallen Leaves" by Menashe Kadiber in the Mery Vod of the Jewish Museum Berlin which I aw as a teenger. This insalhtion is conseructed from over "10,000 open-mouthed faces coarsely cuf from heary circular iron plates [which] cover the floor" in an extremely long, tall and narrow space, as seen in figures $1-3 .{ }^{5}$ The idea behind the exhibition is that the visitor is to walk the length of this space across the thousands of graphic iron faces. When I experienced the space myself something about the scale, lighting, proportion and sound of the space overwhelmed my senses and emotions preventing me from walking out into the space. It was in this space that I felt on an intensely personal and intimate level much more about the "irretrievable loss of the Jews murdered in Europe" during the Second World War than I did in reading the plaques on walls in all the surrounding exhibitions. ${ }^{6}$ As the description of the project states, "Kadishman's sculptures..... evoke painful recollections of the innocent victims of yesterday, today, and tomorrow" ? To this day, this space still holds a strong place in my memory and still gives me goose bumps. 


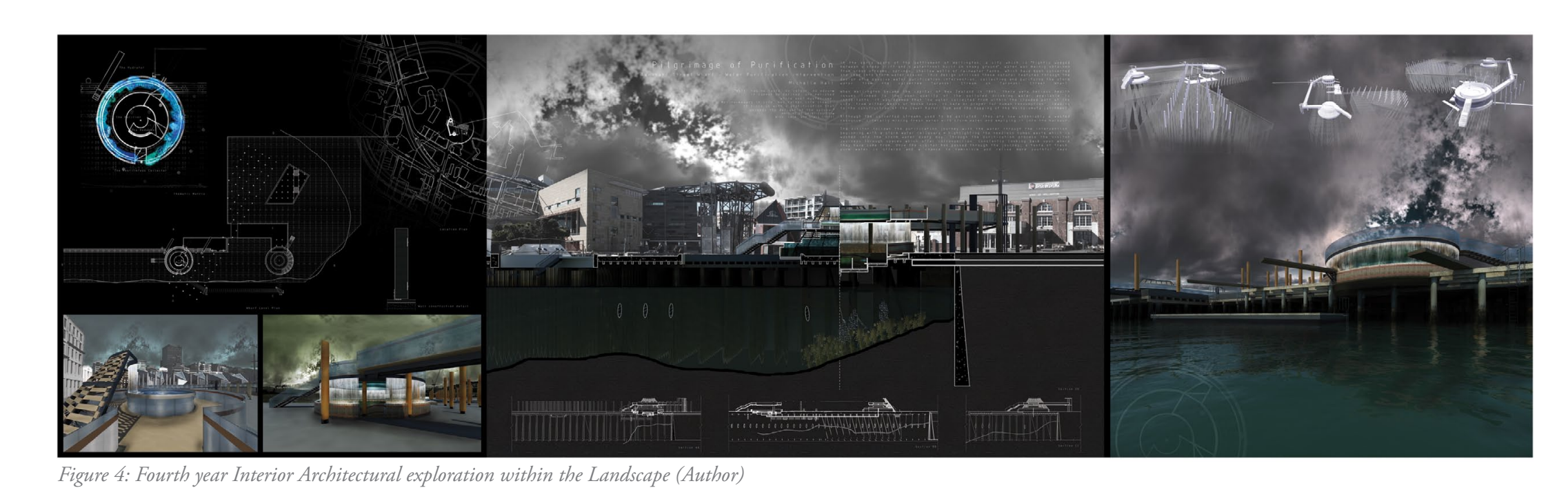

It is this temporal experience of spatial intimacy that opens up the possibilities of expanding the boundaries of what interior is. As Gaston Bachelard describes in The Poetics of Space, "outside and inside are both intimate - they are always ready to be reversed, to exchange their hostility ... Intimate space loses its clarity, while exterior spaces loses its void, void being the raw material of possibility of being.". 8

During my fourth year of study I found the confidence to push Interior Architecture design projects out into contexts that are not 'typical' for interiors and began to try to deal with more complicated concepts of 1 and dealing with stormwater, as can be seen in figure 4 .

So when it came to choosing a topic for my Master's Thesis I was drawn to the somewhat disparate concept of Resilience and how this traditionally Landscape and Urban based concept could apply to Interior Architecture.

There is an interesting connection between Landscape and Interior Architecture. As a discipline Interior Architecture tends to be quite introverted, often struggling to connect to the exterior context of a design and sometimes even to connect to the direct context of the building which houses the design. As a discipline Landscape Architecture tends to be so involved with the context on a large scale that the finer details and experiences of space can be lost. By combining the disciplines landscapes have the potential to generate their own sense of interiority. A further complexity is added when trying to engage with engineered systems. Generally engineered systems tend to be internalized and designed without regard for the social. It is the "practical connection between the large scale and the modification of human and nonhuman connections" that is extremely interesting in this discourse between the three disciplines, that also opens up many design possibilities in regard to this thesis.

$\stackrel{\text { (Bachelard 218) }}{\text { (Ghos, Jazairy, and Ramos 124) }}$ 

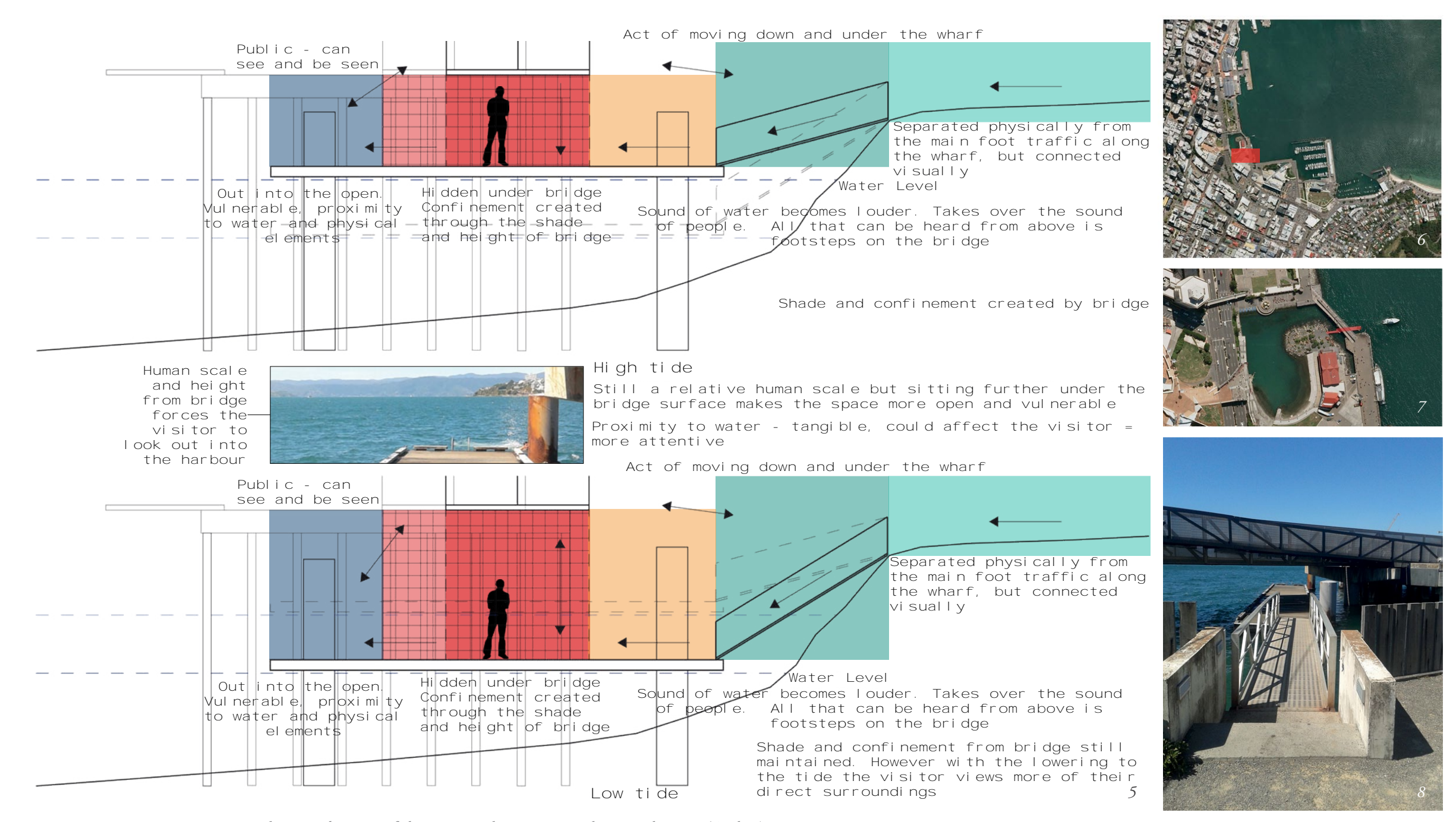

2.0 Positioning

2.1 Existential intimacy

In beginning this research I had a basic view and simple term "intimacy" for the spatial experience I was excited by. It very quickly became clear that the word intimacy by itself is too simple and doesn't encompass all of the spatial qualities I was trying to describe. Intimacy ${ }^{10}$ as a word is often understood as having some sort of romantic connotation and is often referenced as being about a relationship between two people. This general sense of the word does not describe the spatial experience I am attempting to create. In an attempt to try to understand this spatial experience I visited a space along the Wellington waterfront in which I felt I had experienced the idea of intimacy I was trying to convey. This space is a floating jetty which sits below Taranaki Street Wharf, as can s 6 and 7 . In this space the visitor is physically iselated from the main thoroughfre above but visully no

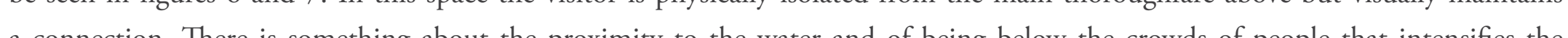

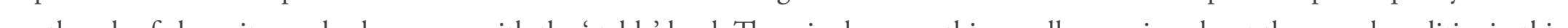
te

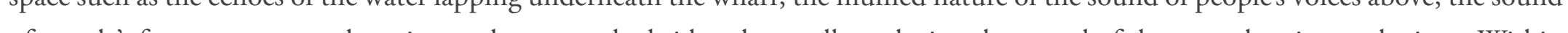

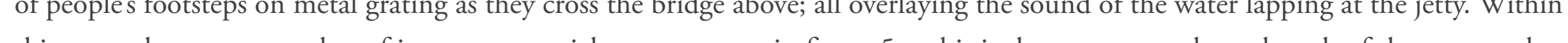
this space there are a number of important spatial zones, as seen in figure 5 and it is the movement through each of these zones that brings together the intense spatial experience. The spatial experience also changes during low and high tide, as when it is low tide the visitor sits further below the bridge and wharf above enhancing the isolation from the people above and intensifying the connection

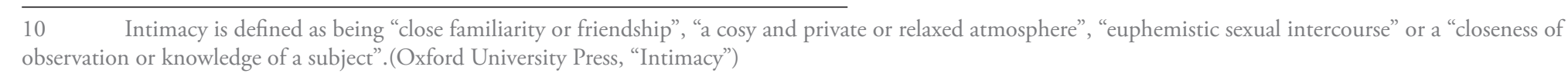




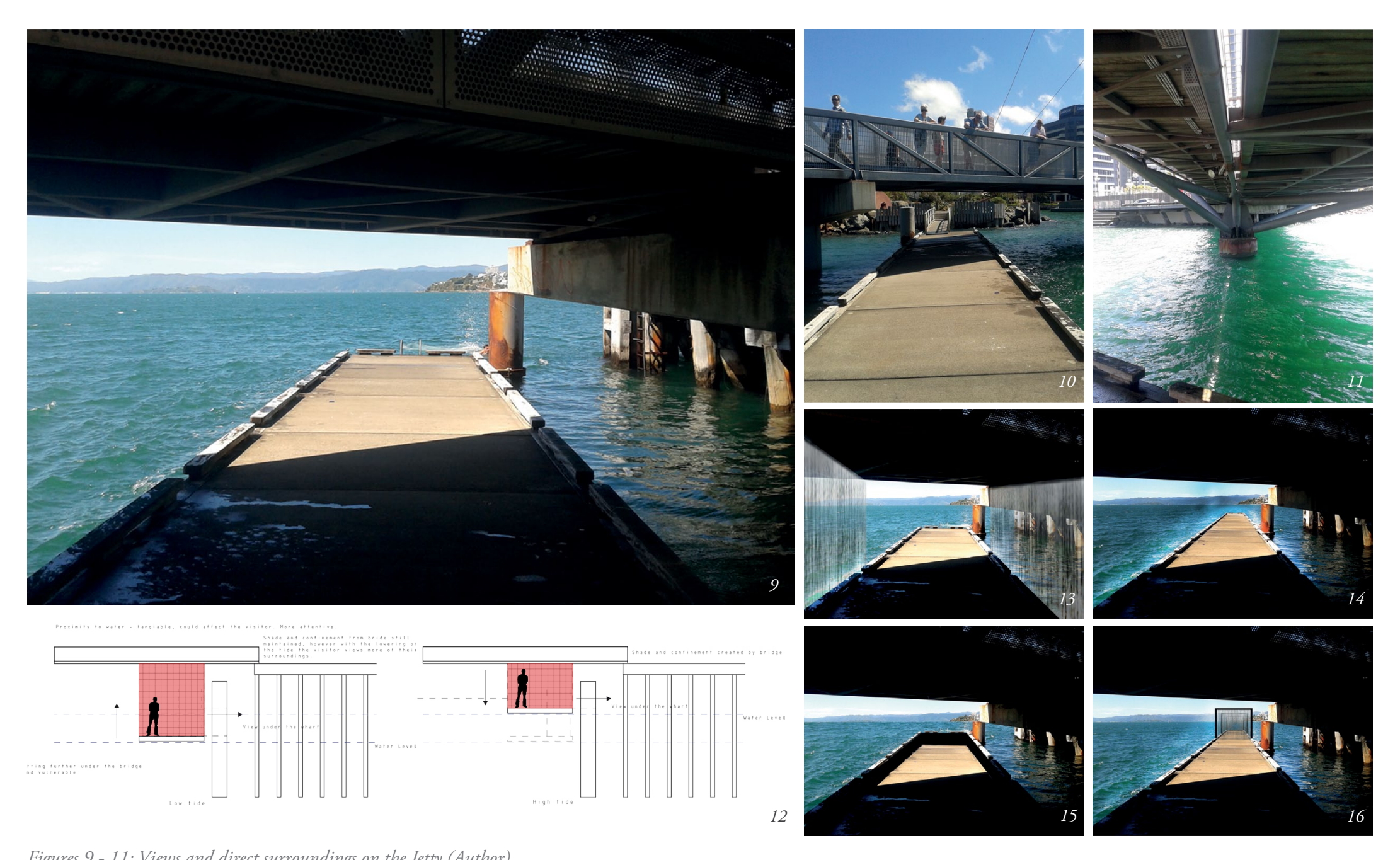

to the water. During high tide the connection to the people above is enhanced through closer physical proximity and clearer sound of the movement above. What is also interesting about this enhanced connection is that the closeness brings a more human scale while something about that salt and the 5 and 12 seek to further detail and explain this experience.

Knowing that this connection to the water was one of the reasons why this space has the spatial experience I was wishing to emulte, the addition of water or enhancing the connection to water in an are wis .

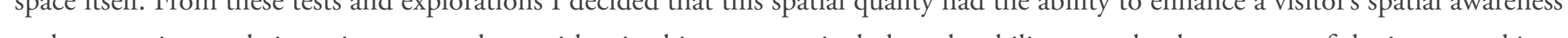
and connection to their avironment, along with - in this space particularly - the ability to make then aware of the inner workings of the wharf. There was acting the spatial experience.

The exercise of interrogating this space to articulate the spatial qualities which aligned to my idea of existential intimacy led me into diagramming the assemblagell of concepts quilites and experiences which have come together to crete this ide of exisentive intimacy (seen in figure 58).

Existential intimacy is about the spontaneous unconscious connection between process, people and space, which through powerful interactions the whole world is opened up for perception. The affect effectively harnesses and redirects the forces of the world into this context. The concept of existential intimacy is about more than just experiencing space. It is about the whole body and its ability 


wociality of water

created by the world

\section{separation/control/redirect/}

separation/control/redirectl
harness forces of the
world for anabilitylafect

$$
\text { HUMAN LIFE }
$$

\section{APTIC}

bodily relationship
to things

EMBODI MENT

territories \& how
things come to life

Bryacess appropriation enables
human' doings'

what is relevant? to sense and engage with space. An existentially intimate space maintains powerful interactions to connect the visitor to the entirety. I have defined "xistential intimacy" to describe the haptic bodily experience of a space through which one gains an understanding of something bigger than themselves (whether it be a system, process, or just being more aware and connected with their direct surroundings).

Existential intimacy reflects a valuable spatial quality and experience as it redirects and controls the forces of the entire world to create an ability or affect which concets the vistor in a create an ability or affect creates haptic, bodily relationships to things and space which allows different spatial territories and their life forces to be experienced and embodied. It removes the banal aspect of processes and places and allows an individual to connect to these mundane things. Existential intimacy also allows a distinguishing between the different types of intimacy and how these allow different types of appropriation. Engaging water with existential intimacy creates an opening into how to deal with political and environmental issues rather than just spatial qualities while using the different manifestations of water to accentuate spatiality and heighten experience to give some sense understanding. Fundamentally, it creates a more meaningful connection between people, process and space, which results in a greater understanding of something bigger 


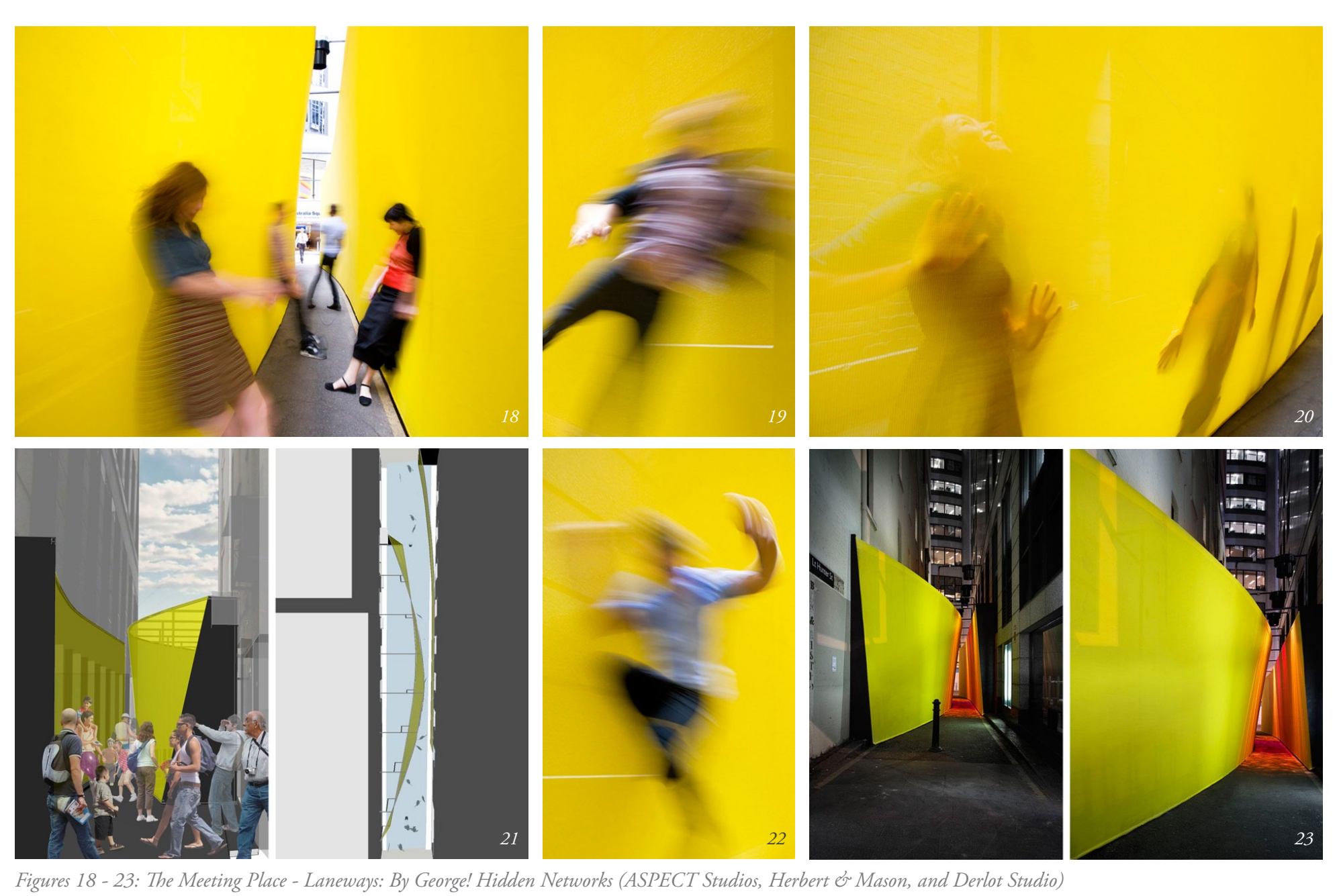

2.1.1 Spatial Example

The Meeting Place - Laneways: By George! Hidden Networks

The Meeting Place is a spatial installation in a Sydney laneway designed by ASPECT Studios, Herbert \& Mason and Derlot Studio for the City of Sydney Council. It is described as "part architectural sculpture, part social experiment" with the idea that it would encourage interaction and participation between people, while "heightening the experience of moving through the urban surrounds

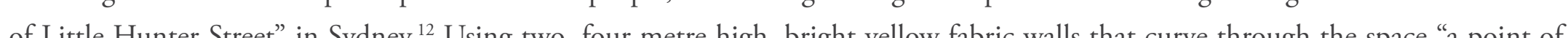
che "chlow Che the

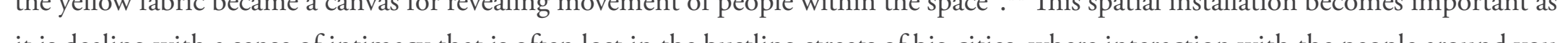
is to tealing wha a is very limited. This space is dealing with a version of forced physical intimacy between people, rather than necessarily an explicit form of existential intimacy. However, one can argue that existential intimacy is present in this space due to the nature of the heightened awareness of people, space, scale and surroundings through the use of this installation - although it is not quite the type of existential

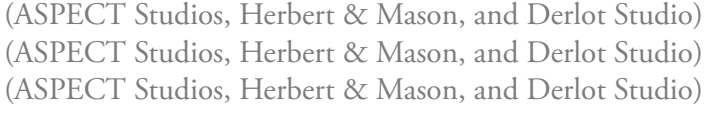


When considering the senses themselves, there is a large amount of discourse around as to how many finite senses there are and how they are linked. Traditionally, we understand that there are five classical senses - sight, sound, taste, touch and smell.

Michel Serres explains in The Five Senses: A Philosophy of Mingled Bodies that "Democritus, who explained sensation by the friction of atoms of different shapes and sizes, thought that all the senses were really only variations of the one sense of touch". 15 Aristotle distinguished four senses as he wanted to "correlate the senses with the four elements - vision with water, sound with air, smell with "sixth , auni-

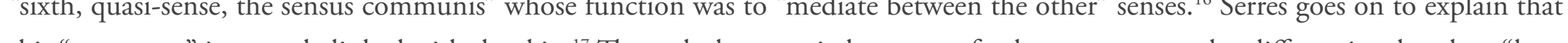
this "metasense" is be the

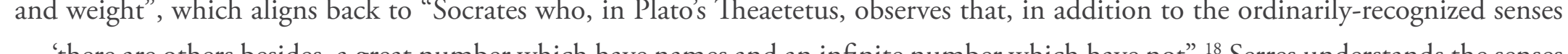

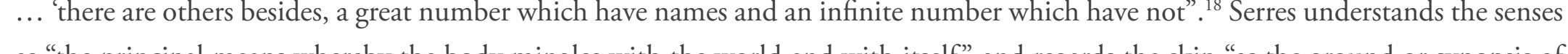
as "the principal mens whe all the senses" as it is "a variety of our mingled senses"."

Psychologist James J Gibson "regards the senses as aggressively seeking mechanisms rather than mere passive receivers" and categorises "five sensory systems: visual system, auditory system, the taste-smell system, the basic-orienting system and the haptic system."20

\begin{tabular}{ll}
\hline 15 & (Serreses 2) \\
16 & (Serres 2) \\
17 & (esrres 2) \\
18 & (Serres 2) \\
19 & (Serres 3) \\
20 & (Pallasmaa 45)
\end{tabular}


In Eyes of the Skin, Juhani Pallasmaa talks about the body as being "the locus of perception, thought and consciousness" and the senses as "articulating, storing and processing sensory responses and thoughts" ${ }^{21}$ When discussing the senses Pallasmaa suggests that "touch is the sensory mode which integrates our experiences of the world and of ourselves" with visual perceptions fused into this "haptic continuum of the self" ${ }^{22} \mathrm{He}$ sees all of the senses as being "extensions of the tactile sense" and "specialisations of skin tissue", explaining that all sensory experiences are "modes of touching" which define the "interface between the skin and the environment" and that we can even "see by our skin" through its ability to distinguish a number of colours. ${ }^{23}$ Pallasmaa discusses that the "eye is the organ of distance and separation, whereas touch is the sense of nearness, intimacy and affection" and that a detachment of the two could not "have any idea of distance, outness, or profundity, nor consequently of space or body". ${ }^{24} \mathrm{He}$ goes on to explain that "vision is direction, whereas sound is omni-directional" and creates an "experience of interiority", that the "most persistent memory of any space is often smell" with the body only needing "eight molecules of substance to trigger an impulse of smell in a nerve ending" while being able to "detect more than 10000 different odours" and that "our skin traces temperature spaces with unerring precision" turning these sensations "into experiences of space and place". 25

For existential intimacy to occur, all of the senses have to be addressed simultaneously in order to "help to fuse our image of self with the experience of the world."26 It is about pulling together the realms of multi-sensory experience to interact and translate "qualities of space, matter and scale", bringing "the world into a most intimate contact with the body" which strengthens ones existential "sense of being in the world, and $\ldots$ essentially a strengthened experience of self . ${ }^{27}$

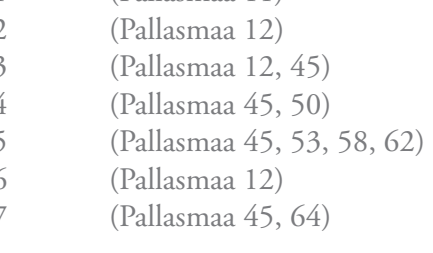


2.3 Existential intimacy and Water

Water can be used as an important device for existential intimacy to occur enhancing the ability to engage with larger systems, spaces and more of the senses.

Michel Serres describes water as being "a sensorial base line ... an exceptional fluid in many ways and what is more, odourless, colourless, tasteless. Elusive and almost intangible nearly translucent, still when nothing disturbs it, noiseless", vet somehow water has "taste, colours and an aroma that tells us where it came from". ${ }^{28}$ Water has the ability to engage in multiple senses, enhancing spatial experiences and volumes. As Juhani Pallasmaa describes in Eyes of the Skin,

"anyone who has become entranced by the sound of dripping water in the darkness of a ruin can attest to the extraordinary capacity of the ear to carve a volume into the void of darkness. The space traced by the ear in the darkness becomes a cavity sculpted directly in the interior of the mind.".2"

It is this ability of water to cross all of the senses and create expansiveness that makes it such a central element when creating existential intimacy. Automatically, the connection with the sound of the dripping water in the example above connects with multiple senses and engages the imagination to create sense of space in the mind. Sound is not the only sense that is activated though; it is the "constant interaction of all sense modalities" that strengthens "one's sense of reality" and the haptic nature of existential intimacy. ${ }^{30}$

Juhani Pallasmaa, Steven Holl, and Alberto Pérez Gómez discuss water as being "a 'phenomenal lens' with powers of reflection, spatial

$\begin{array}{ll}28 & (\text { Serres } 169) \\ 29 & \text { (Pallasmaa } 54) \\ 30 & \text { (Pallasma 44-45) }\end{array}$ 


\begin{tabular}{|c|c|c|c|c|c|}
\hline frozen & vapour & icel & snow/hail & fall & waterfal \\
\hline spiritual & reflect & & waves & evaporation & da mp \\
\hline spill & dam & & spray & hard/soft & pure \\
\hline tasteless & life-giving & & soak & sprinkle & $c$ lean \\
\hline rough & & WATER & QUALI TIES & & stream \\
\hline crystals & mist & $\operatorname{manif}$ & festations & pool & calm \\
\hline rapid & gas & & mel t & transparent & ebb \\
\hline white water & rain & & flood & colourless & flow \\
\hline puddle & salty & & ast/slow & wet & dirty \\
\hline
\end{tabular}

reversal, refraction, and the transformation of rays of light" in Questions of Perception.31 They also explain that the balance between "the science of water and the exhilarating qualities of experience" are found in "the many states and transformative properties" of water, giving the example of reflections on the bottom of a still pool of water, in which "we can often see intense focal lines of sunlight projected by the crests of wavelets acting as lenses" which allows the "psychological power of reflections [to] overcome[s] the "science" of refraction." "' It is not only the physical manifestations of water, but also the ability of water to transform "light through material [which] can present poetic tools for making spaces of exhilarating perceptions.".

Gaston Bachelard talks about the intimacy of water in The Poetics of Space, referring to water as a "space-substance" with the "mark of limitlessness" "34 He describes the idea of reflections "in water [being] the first view that the universe has of itself", heightening the

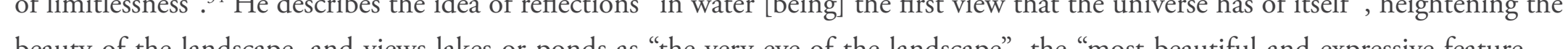
looking into which the beholder measures the depth of his own nature" 35

David Leatherbarrow adds to explain that water "exaggerates these qualities of shapeless territory", and "has the virtue of unselfish willingness to sacrifice its present form for the shape of its next container ... The pressure it exerts substantiates shape" 36 It is this flexibility of water that allows it to cross through many spaces, manifestations and create so many different experiences.

It is waters ability to change through so many different manifestations while still maintaining its identity that makes it such an exciting material or element to work with. Pallasmaa proposes the idea that natural materials “allow our vision to penetrate their surfaces and 
design problem $\longrightarrow$ how can stormwater how can intimacy be
created in bign?
stormater design?

territories
global positioning

$\underset{\substack{\text { intimacy } \\ \text { experience }}}{\uparrow}$ maintaining
interiority pushing boundaries
of "interior"

discplinary problem

removing focus from process

water essential to all life

STORMWATER DESIGN

currenty focused on system

intimacy +heightened
experience of space relating to co

relating to contex

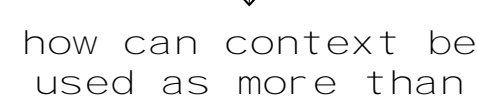

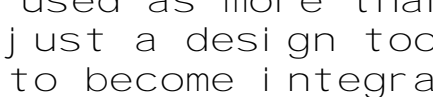

become integral
to design?

technical apsects of stormwater $+\sqrt{ }$ qualities ${ }^{2}$ of water

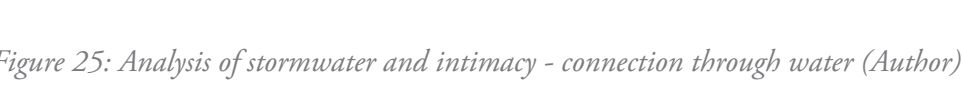

(Pallsmaa 34)
37
39
39

enable us to become convinced of the veracity of matter" with the "patina of wear add[ing] the enriching experience of time to the materials", suggesting that current design and construction is weakened by a flat sense of materiality. ${ }^{3}$

The versatility of water makes it an essential element in terms of existential intimacy and also when engaging with larger systems, such as the landscape and engineered systems like stormwater. By dealing with stormwater, the use of water as a device for existentid intimacy has dual use - not only to deal with the stormwater but also to dealing with the politis ha minto . are all polita ing ... are all political the sense that they represent an evolving issue". ${ }^{3}$ "This further aids in connecting "humans and nonhumans" and 


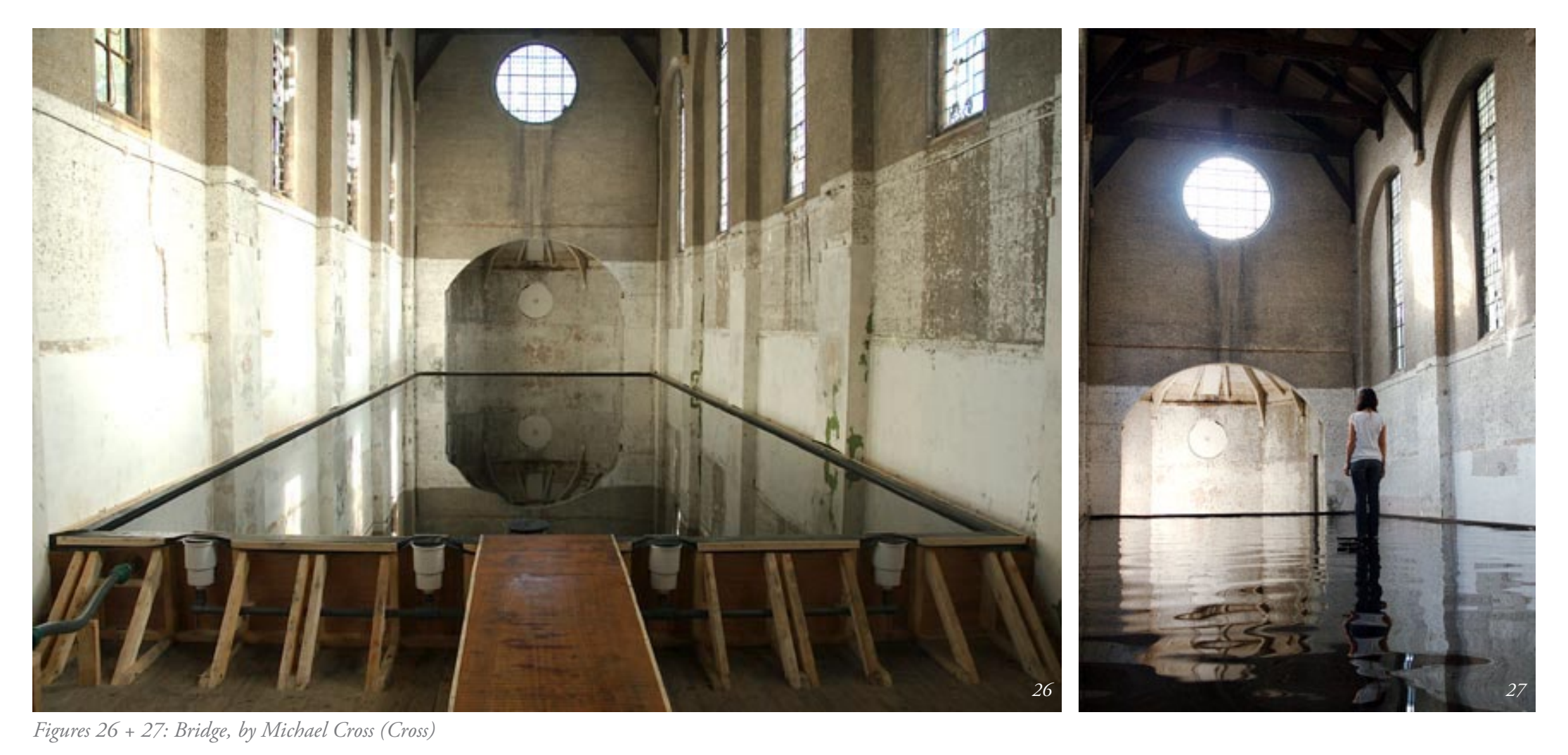

2.3.1 Spatial Examples

Bridge

Bridge by Michael Cross is a spatial installation in an old, abandoned church which is now used for art in Dilston Grove, south-east London. ${ }^{40}$ The installation is a large pool of water (60 centimetres deep, 54000 litres of water) which fills two thirds of the empty church. .1 $^{11}$ Within this pool of water "is a series of steps which rise up out of the water in front of you" as you walk across, and "disappear back underneath behind you as you go, leaving you stranded with only one step visible in front of you and one behind" 2 "When

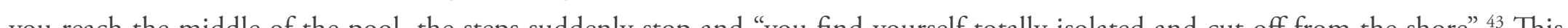

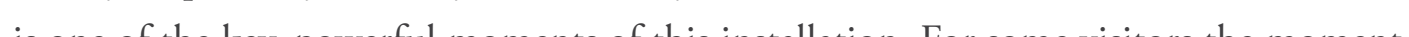
of beigouln he wer bing " be be esconed backe we he

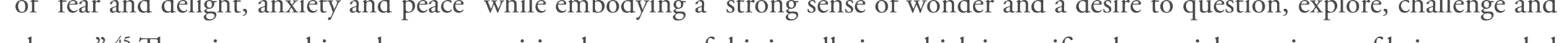
change" ". There is something about very spiritual context of this installation which intensifies the spatial experience of being stranded in the water, and somewhat ironically, it is through the feeling of walking on wate, hat the vistor's sensory perception is first shifted. The water is not deep, and one can tell that from the outside of the pool, but as soon as one is walking on the small steps as they pop up out of the water, the water seems much deeper and it is through this experience that the visitors fears begin to bubble to the surface. 


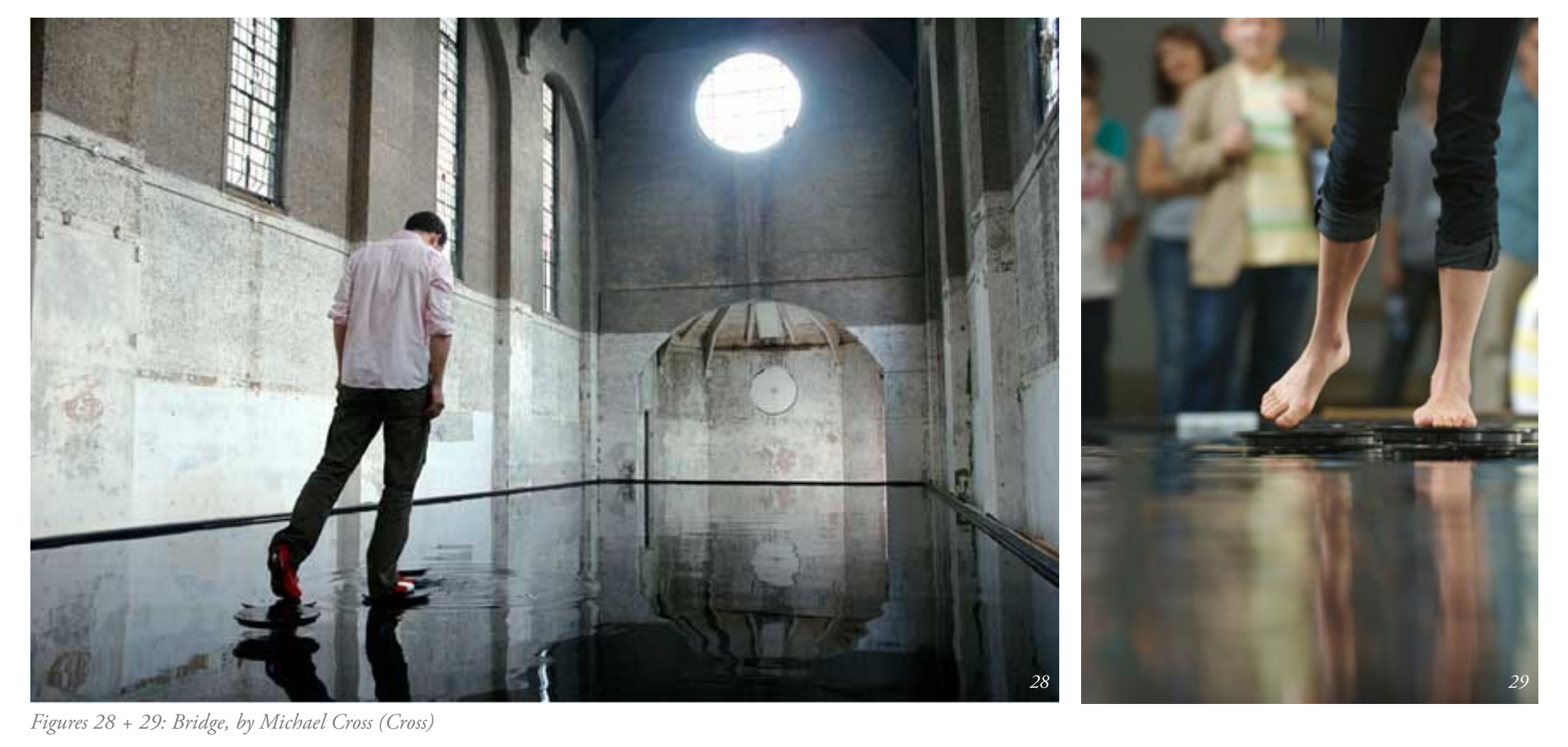

Perhaps if the steps were stationary this space would not have the same effect, but something about the way that they ripple the water as they move up and down, unsettles the experience. The artist explained that when the installation was going, they ended up deciding

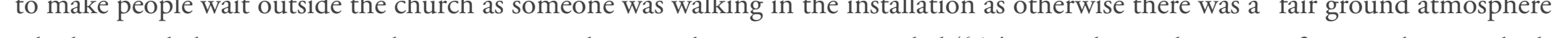
which ruined the intense spatial connection and spiritual experience intended." The simple employment of water along with the moving steps really heightened this spatial experience and is a great example of existential intimacy. 


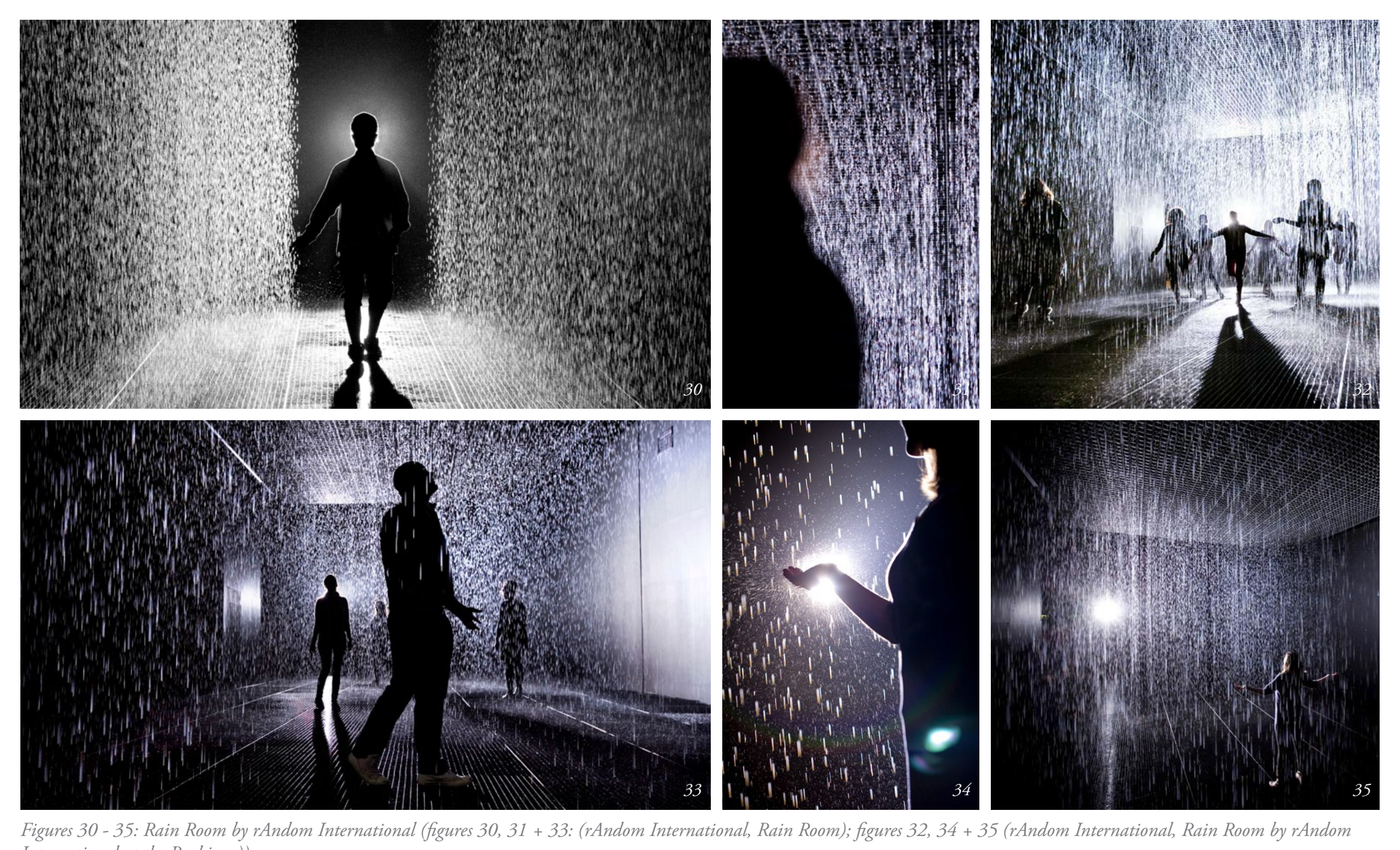

Rain Room

Rain Room by Random International, is a $100 \mathrm{~m}^{2}$ spatial installation that has been housed at the Barbican in London and also at MoMA in New York 47 The insellhion is simply described as " "Feld of fllling witer through which it is possible to walk... withour being drenched in the proces", 48 As you apposh and anter he of (The Curve at the Babien), "he sond of water and a

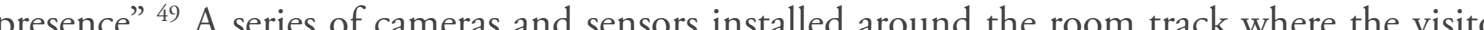
flow of water above them accordingly, creating a cocoon of dry space surrounded by a wall of water ${ }^{50}$ The water falls through a grated Aloor "where it is treated before being sent back up to the ceiling to fall gain" "sl The act of being surounded by rain yet not getting wet creates an intense spatial experience - light sources are scattered around the space but the pure focus of the installation is on the sound of the rain and the water falling through the space which creates "an intimate atmosphere of contemplation". 2. The intention of this installation is to "explore the behaviour of the viewer and the viewers: pushing people outside their comfort zones, extracting their base auto-responses and playing with intuition.".53 This installation truly encompasses existential intimacy as the body senses and expects rain to touch it, yet through the technology and the installation, does not get wet. This throws out the general expectation of the space and enlivens the experience. 


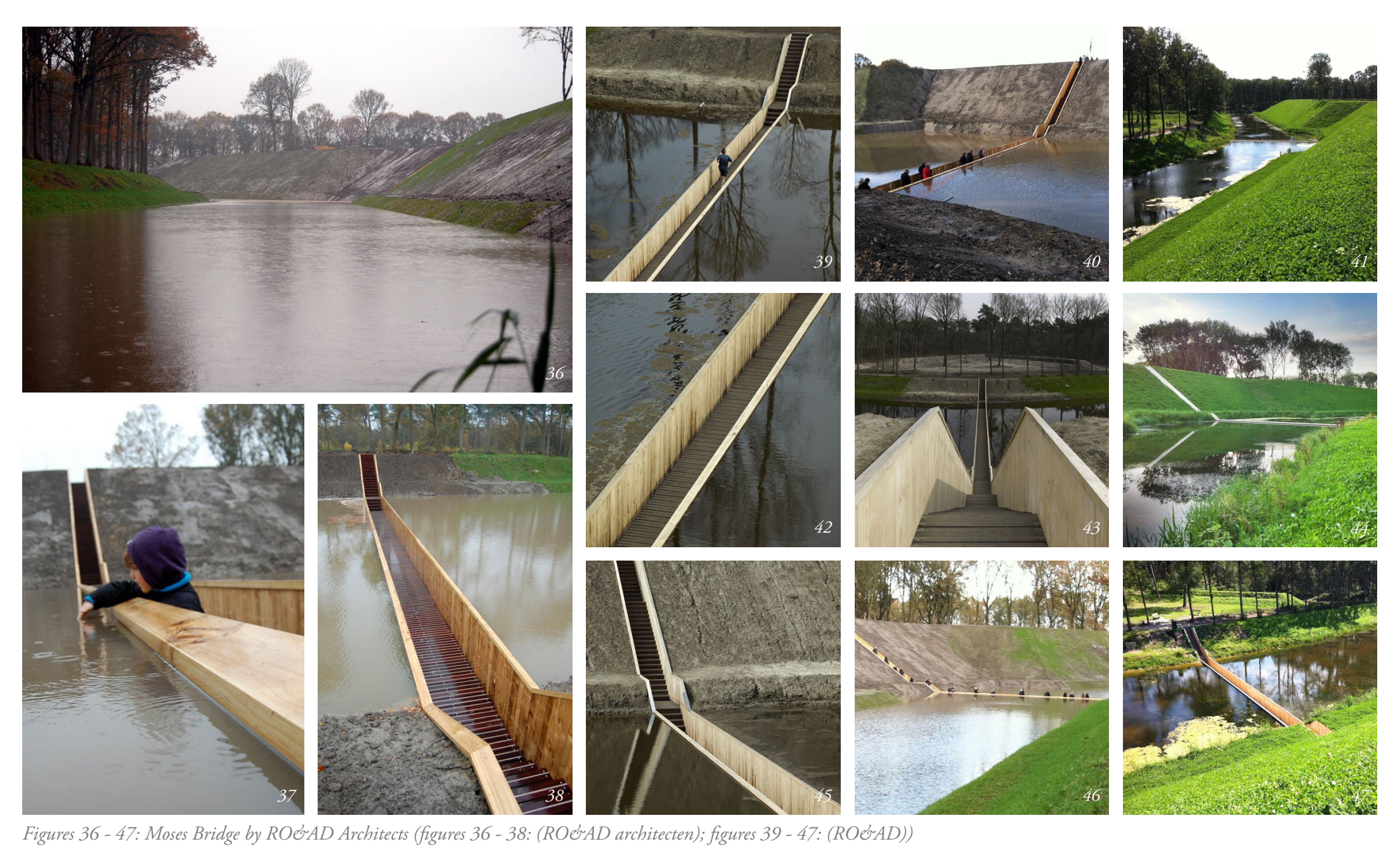

Moses Bridge

The Moses Bridge by RO\&AD Architects is a sunken bridge located in a historic fort, Fort de Roovere, in Halsteren, The Netherlands. .4 $^{54}$ The bridge was created as the $17^{\text {th }}$ century defence-line of The West Brabant Water Line consisting of earthen fortresses and walls that linked and protected cities and villages "with inundation areas $5^{55}$ in the south-west of the Netherlands ... fell into disrepair in the $19^{\text {th }}$

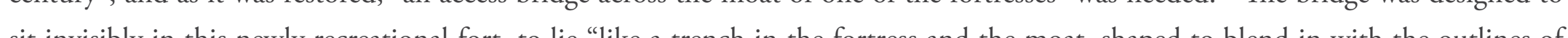
the yet saying dry while crossing the mort hit enconases ese in this situation allows a more meaningful connection to be made. It is not often that one can be at the same level as the water and experience it in such a way. The direct path that creates this movement downwards is also important as it is perhaps this movement down into the land that emphasizes the experience and existential intimacy of the intervention. The approach is also very important as when the bridge is empty, it is nearly invisible, but when people are crossing, the visitor only sees a dissected portion of people floating across the water. 


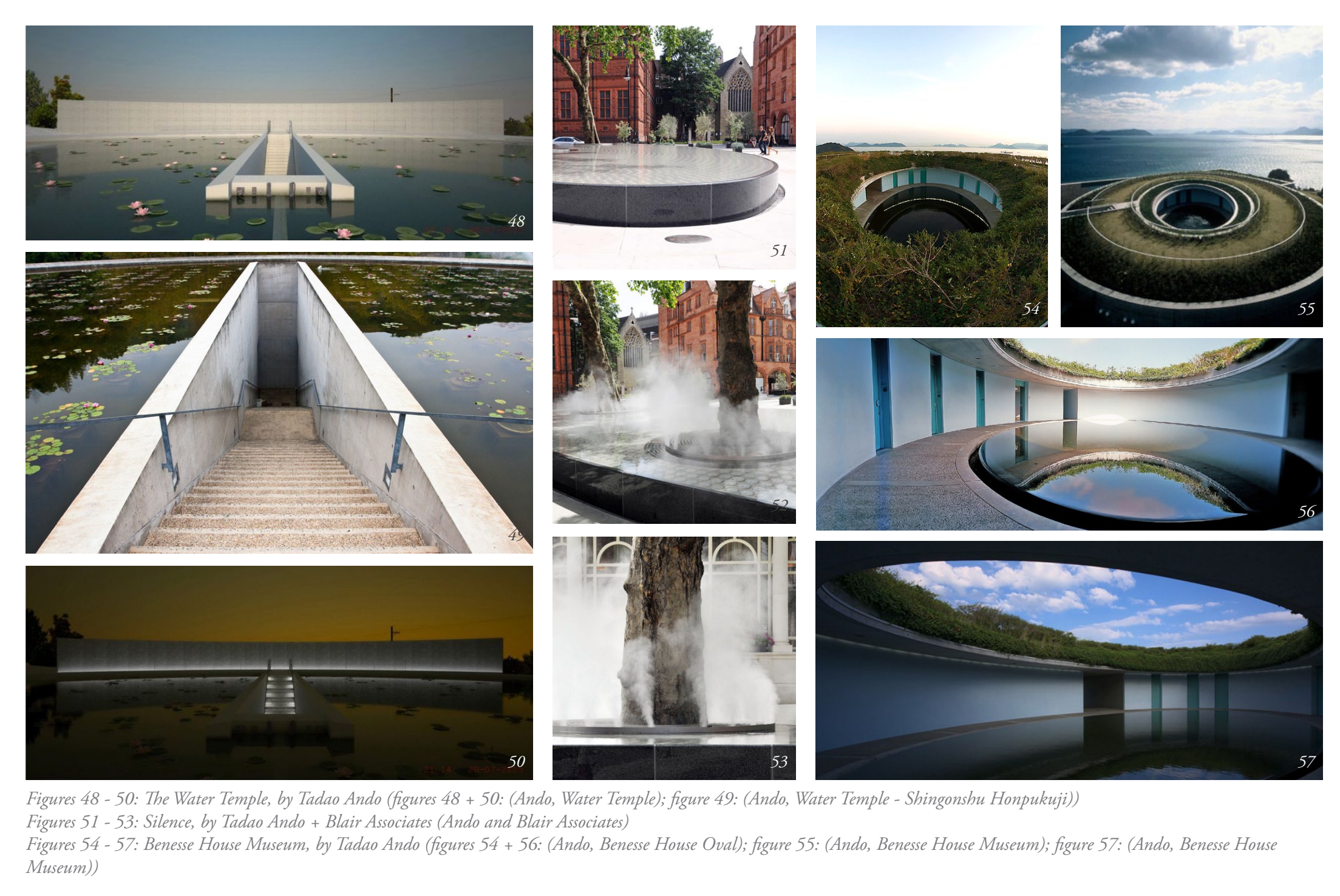

Tadao Ando

Tadao Ando is a Japanese architect who utilises the manifestations and existential qualities of water to enhance his designed spaces and

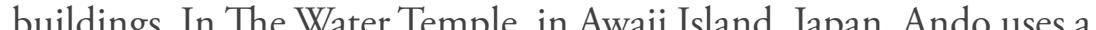
a cleansing ritual as one London, Ando uses the nat

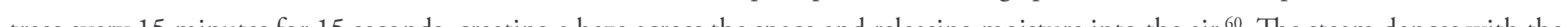
1ig

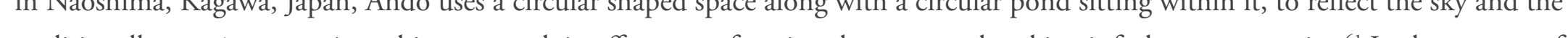

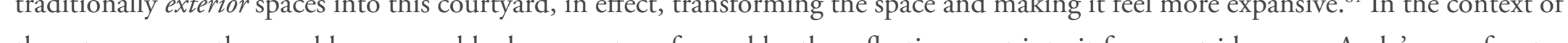
the art museum, the pond becones a blank canvas transformed by the refections cast into it from ousside space. Andos use of water is often in pond or pool form, but the way this pond or pool is incorporated into spaces with the manifestations of water as well as the

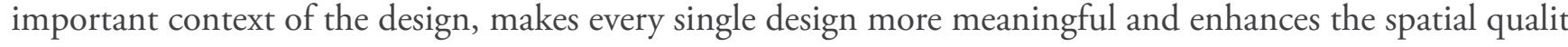




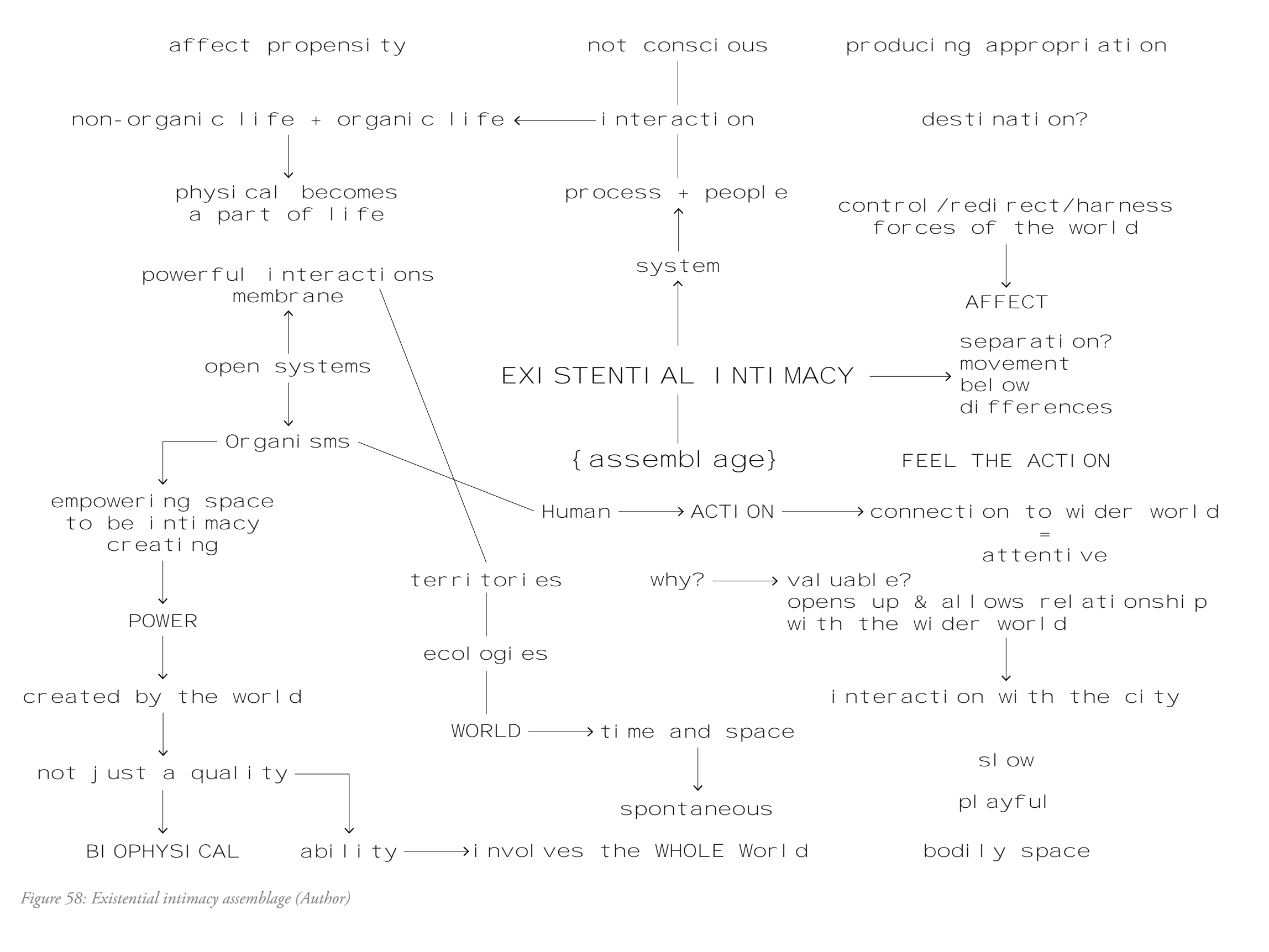

2.4 Affordances, Assemblage Thinking and Existential Intimacy

For the purposes of this research, it is really important to analyse, understand and explain existential intimacy by using the theories of affordances and assemblages. These theories will form the basis of how the investigated and designed spaces will be explained.

The theory of affordances is a concept created by psychologist James J Gibson which brings forth the idea of an affordance as being what is provided, offered or furnished, either for good or ill, for a space, animal or person. . $^{6}$ It is a concept which "refers to both the environment and the animal in a way that no existing term does. I timplies the complementarity of the animal and the environen Gibson made up the noun affordance as only the verb afford was found in the dictionary so describing this concept became difficult ${ }^{64}$ An for

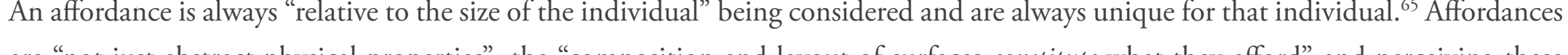
surfaces "is to perceive what they afford". 66 For example,

"Surfaces afford posture, locomotion, collision, manipulation, and in general behaviour. Special forms of layout afford shelter and concealment. ... The other animal and the other person provide mutual and reciprocal affordances at extremely high levels of behavioural complexity."67

Substances, objects, surfaces, places, mediums and other animals "have affordances for a given animal" offering positive or negative

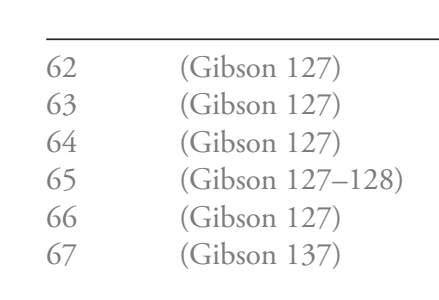


outcomes, "They need to be perceived".68 Affordances are "neither physical nor phenomenal" and are "properties taken with reference to the observer."69 They are more about "bow an animal lives than to where it lives" and do not change if the needs of the observer or animal change. ${ }^{70}$

The concept of an assemblage is defined as being "a collection or gathering of things or people" which come together to create a specific experience, object or space. ${ }^{71}$ Assemblages are important for this research as they talk about the combination of elements which come experience, object or space. Assemblages are important for this research as they talk about the combination of elements which come
together to create existential intimacy or other spatial experiences. This concept will be used again as a basis for how the selected spaces together to create existential intimacy or other spatial experite
are explained in terms of their existential intimacy power. 
2.5 Representing Existential Intimacy

How does one represent such an intangible spatial experience, the "unanalysable architecture of the senses"? ?72 It is not an experience that can be sketched out simply as it represents so many different elements - how do you draw taste, temperature, sound, etc. without simply describing it in words? As Holl, Pallasmaa and Pérez Gómez explain, design "is not an experience that words translate later. Like the poem itself, it is its figure as presence, which constitutes the means and end of the experience", the temporal dimension is fundamental to engage with all of our sensory perceptions. ${ }^{73}$ Typically, Interior Architecture is based around viewing space in the perspective, visualising in three or four dimensions and primarily in digital form, whereas Landscape is based more in large scale plans and sections, again usually digital but there also some interaction with the hand. It is an interesting interface between representations and also disciplines, as how does one tackle the large scale while also interacting with the details? The concept of existential intimacy becomes an important tool to do this.

Interestingly, as the design process unfolded throughout this thesis, I found myself using digital representations only as an aid when creating images and explorations by hand. As Pallasmaa explains

computer imaging tends to flatten our magnificent, multi-sensory, simultaneous and synchronic capacities by turning the design process into a passive visual manipulation, a retinal journey"

by creating distance between the object and designer, "whereas drawing by hand as well as working with models put the designer in a haptic contact with the object, or space."?t

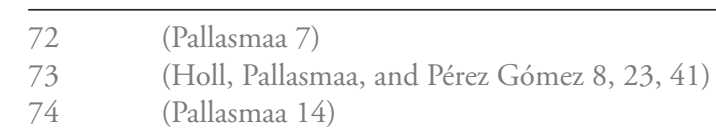


When considering the concept of viewing space in perspective, just how that perspective is represented becomes particularly important in order to enhance the concept of existential intimacy. Pallasmaa describes an interesting concept regarding peripheral and unfocused vision, suggesting that "a remarkable factor in the experience of enveloping spatiality, interiority and hapticity is the deliberate suppression of sharp focused vision", proposing that "the very essence of the lived experience is moulded by" this unfocused vision and the "unconscious haptic imagery".75 Pallasmaa states that "focused vision confronts us with the world whereas peripheral vision envelops us into the flesh of the world" by allowing us to experience the existential "preconscious perceptual realm" integrating us with space rather than pushing us out of space as focused vision does. ${ }^{76} \mathrm{He}$ also believes that we close off "the distancing sense of vision" during overpowering emotional experiences, and because of this "deep shadows and darkness are essential" as they "make depth and distance ambiguous, and invite unconscious peripheral vision and tactile fantasy."'

It is important to try to articulate the other sensory elements in the spatial experiences as "the isolation of the eye outside its natural interaction with other sense modalities ... fragments the innate complexity, comprehensiveness" and reinforces "a sense of detachment and alienation" as "an architectural work is not experienced as a collection of isolated visual pictures, but in its fully embodied material and spiritual presence" 78 The challenge becomes more about creating "a new dynamic conception of both image and architecture" and spiritual presence."77
the challenge becomes more about creating "a new dynamic conception of both image and architecture"
thring "movement" and "time images" that "belong to a dynamic rather than static geography" which attempts to reproduce the world..$^{79}$ It is the act of creating an innovative "flow of time" which allows the representation of the experience of space to be meaningful rather than represented in a way in which nobody ever sees them. ${ }^{\text {so }}$

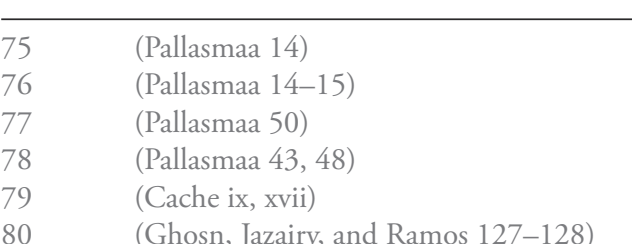


When designing with a focus on existential intimacy an expansiveness across scales is created, meaning that the design cannot lose context or detail but is forced to engage with both to create spaces which are both functional (in an engineered and practical sense) and experiential. The challenge of representing these spatial concepts will be tested and attempted by using the discussed techniques in a way that articulates and expresses the spatial identity and existential intimacy of place. 
Existential intimacy acts as a powerful catalyst to bring together usually disparate concepts in the case of this research, interior, landscape and engineered infrastructure. Engineered infrastructure and landscape often have a connection when trying to make infrastructural systems inhabitable, but there is often times a missed opportunity to create the most meaningful dialogue which is where the specialisation of interior becomes important. As a discipline however interior tends to not relate to site and context very well often completely ignoring it to create a temporally isolated design which is where the integration with landscape becomes important as landscape is obsessed with site and context often times losing the details through this large scale focus. Often engineered infrastructure is so focused on the functional aspect that it misses the ability to integrate into meaningful experience and often attempts to make the interaction with the functional side meaningful are unsuccessful. In the case of this research specifically, stormwater infrastructure has been chosen to be focused on particularly due to the spatial qualities of water and its ability to transform space and experience as explained above. Stormwater also becomes an important piece of infrastructure as it one that is literally connected to the world - rain falls in cities which then drains into stormwater culverts which flow out into the ocean - an element which connects the entire world. The use of stormwater also makes the design practical and problem solving firmly rooting a spatial installation as a necessity.

Pallasmaa illuminates well that "architecture, as with all art, is fundamentally confronted with questions of human existence in space", it is "deeply engaged in the metaphysical questions of the self and the world, interiority and exteriority, time and duration, life and death". ${ }^{81}$ Buildings and cities provide "the horizon for the understanding and confronting of the human existential condition" and to be existential have to relate to the body "the city and my body supplement and define each other" .2. "The percept of the body and the

P1 2 (Pallasma 19) 
image of the world turn into one single continuous existential experience". ${ }^{83}$ Buildings and cities act as "instruments and museums of time" enabling us to "participate in time cycles that surpass individual life" with their own individual echo. ${ }^{84}$ He suggests that "architecture is essentially an extension of nature into the man-made realm" which "presents the drama of construction silenced into matter, space and light". ${ }^{.5}$

The articulation and testing of this spatial experience makes sense within the landscape and the city as Pallasmaa suggests that "a walk through a forest is invigorating and healing due to the constant interaction of all sense modalities" in essence a "polyphony of the senses" a concept which is central to existential intimacy as the desire is to engage with all of the senses to bring "the world into a most senses a concept which is central to existential intimacy as the desire is to engage with all of the senses to bring "the world into a most
intimate contact with the body. as one is not contained within a building. It is through the integration of the technical and the poetic, the large scale of infrastructure as landscape with the human scale and existential connections that has the potential to unveil "a fuller sense of landscape" and place. . $^{87}$ and landscape with the human scale and existential connections that has the potential to unveil "a fuller sense of landscape" "and place.
The transformation of day-to-day experiences brings means that "intimate space loses its clarity, while exterior space loses its void", The transformation of day-to-day experiences brings means that "intimate space loses
merging and entwining interior and exterior, creating an expansiveness of experience. ${ }^{88}$

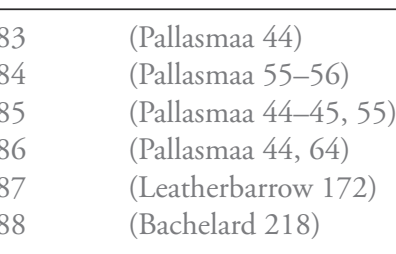




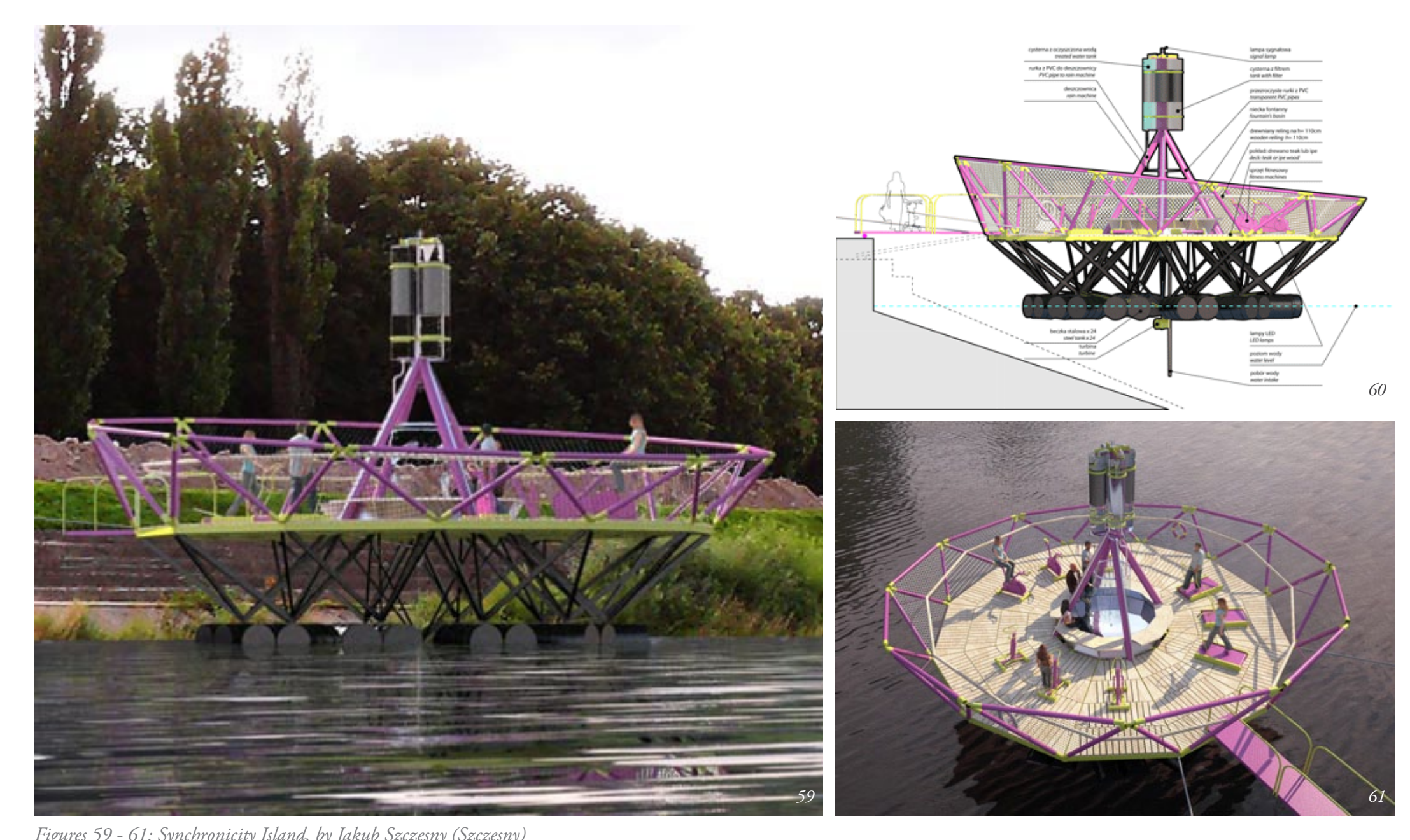

2.6.1 Spatial Examples

Synchronicity Island

Synchronicity Island is a floating island designed by Jakub Szccesnny to sit on a river in Warsaw. ${ }^{89}$ The island, powered by exercise machines, is designed to clean and purify the polluted water in the river by kinetically pumping it through four filters and tanks connected to the exce

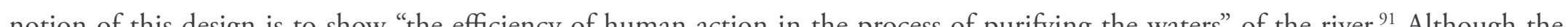
color is lost through the gimmicky form and articulation of the design. 


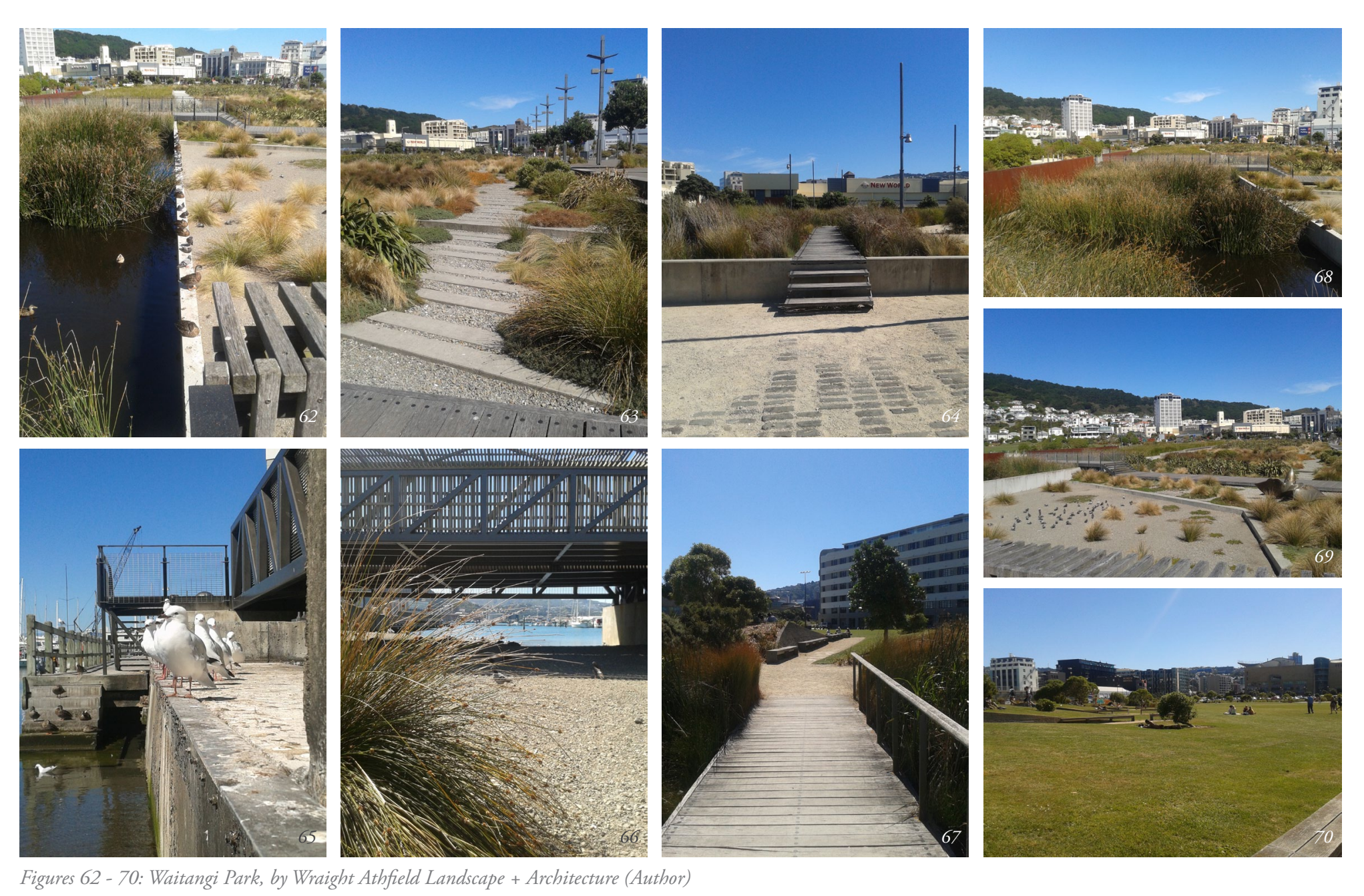

Waitangi Park

Waitangi Park designed by Wraight Athfield Landscape + Architecture, is a local Wellington design that I was easily able to access

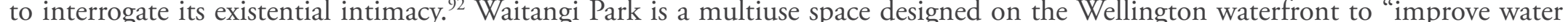

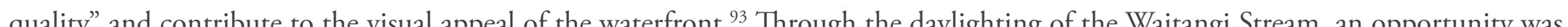

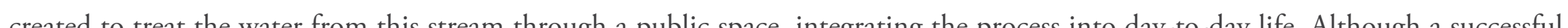
pelle

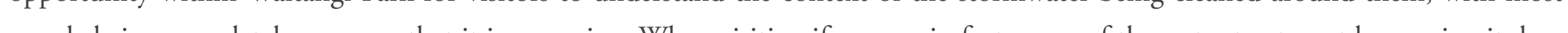
people beng conty 


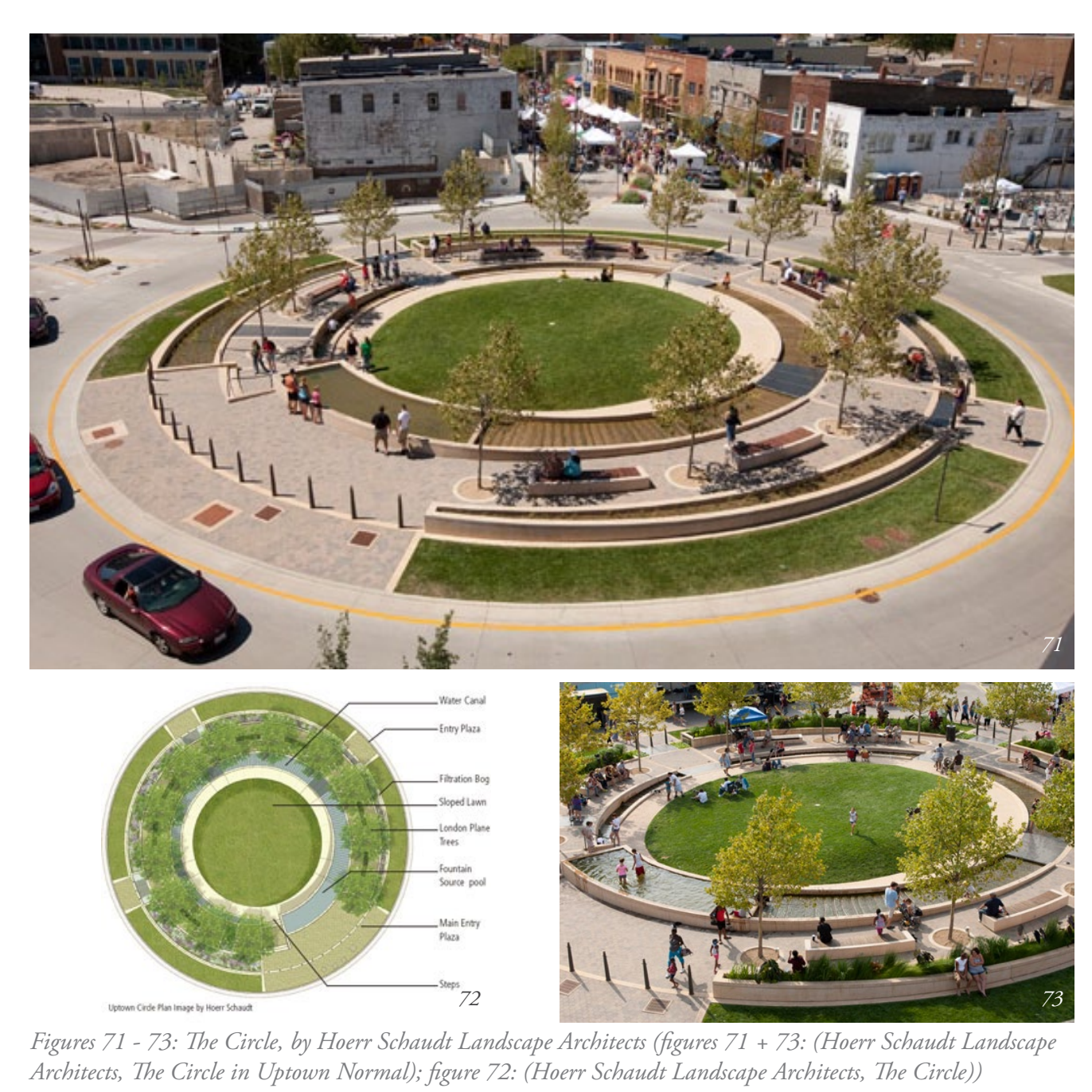

The Circle

The Circle is a roundabout in Illinois, designed by Hoerr Schaudt Landscape Architects. ${ }^{94}$ The roundabout is designed to be multi-

functional and sustainable by cleaning and re-circulating stormwater "into a public fountain", managing and improving traffic while providing "community green space".95 Although a clever use of usually wasted and uninhabited space, this design also lacks the existential connection to the context of the water treatment and what that means for the local context. It provides a public forum that could be enhanced to create a more meaningful connection to the water and by being surrounded by the traffic circulating the roundabout, an existential moment could occur, but has ultimately been missed. 


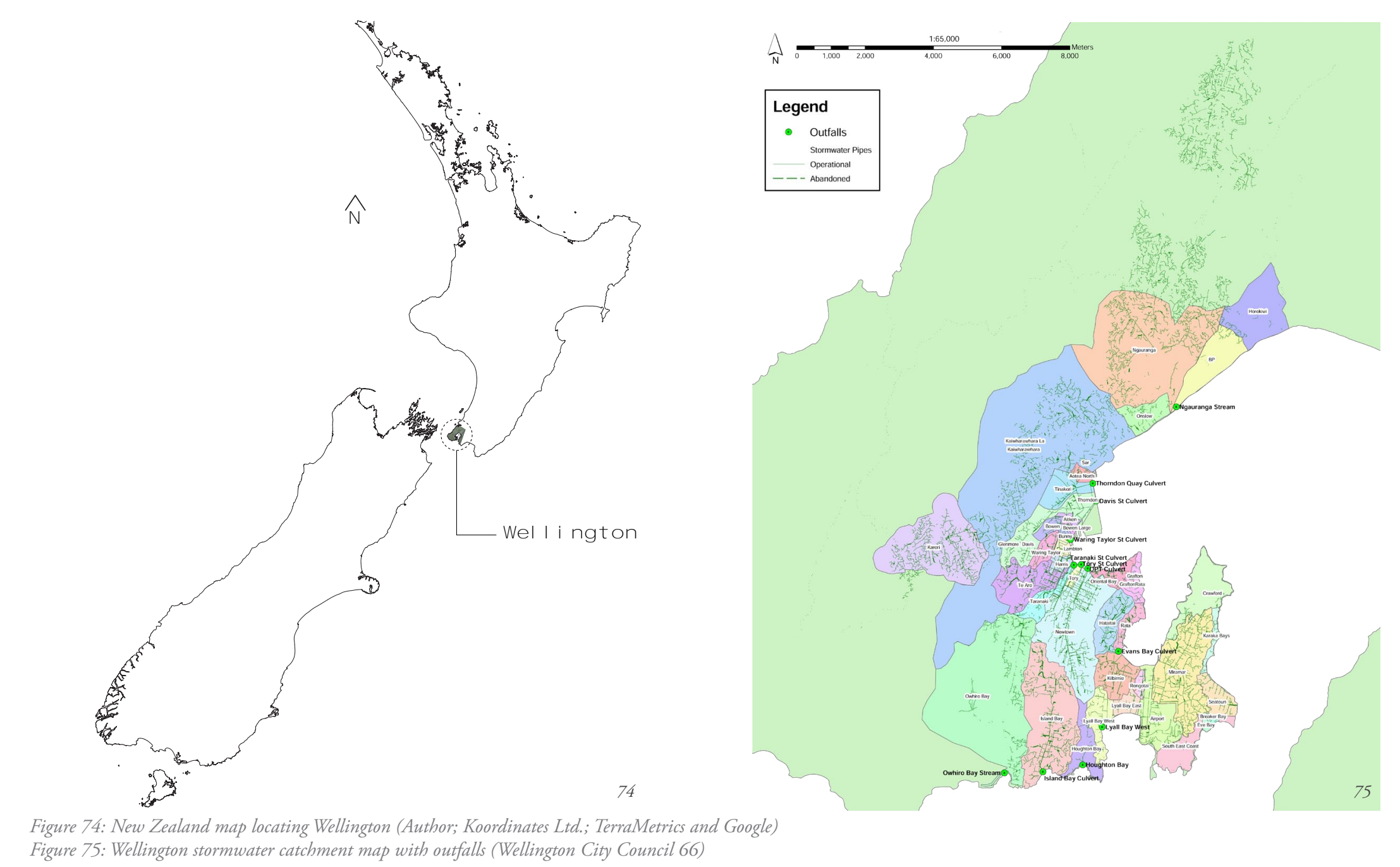

3.0 Design Investigation

3.1 Site

Due to my limited knowledge of landscape and stormwater design it became important for a local context and site to be chosen for this research and design exploration. Wellington city is located at the bottom of the North Island of New Zealand (as seen in figure 74), with around "200 hours of sunshine a year" and temperatures between $19^{\circ} \mathrm{C}$ to $24^{\circ} \mathrm{C}$ in summer, and $6^{\circ} \mathrm{C}$ to $9^{\circ} \mathrm{C}$ in Winter. $9^{6}$ Wellington enjoys plenty of rain with a $55 \%$ daily chance of rain throughout the winter months and, is a very windy city due to its location relative to the Cook Strait and surrounding hills. ${ }^{97} \mathrm{I}$ began by looking at Wellington as a whole and came to understand how the city was broken up into 42 different catchments, seen in figure $75 .{ }^{.98}$ When comparing the different catchments I took into account the size of the catchment area, interesting locations within the catchment area that had potential for existentially intimate designs, and the relationship between the different catchments. In the end I chose the Newtown catchment as its large area meant that it provided many different areas and opportunities for development and testing of designs particularly a large number of public and green spaces, as can be seen in figure 76. The Newtown catchment, covering 442 hectares encompasses the Wellington Zoo along with the city side of Mount Victoria, some of Mount Cook, and Waitangi Park and Clyde Quay Wharf along the waterfront."

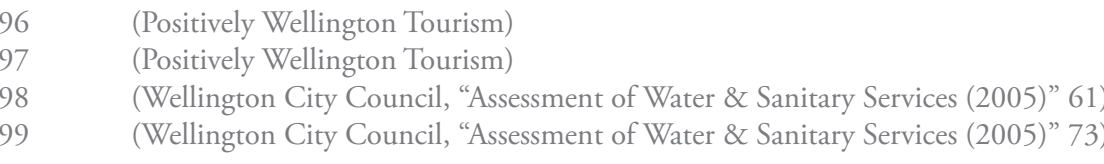




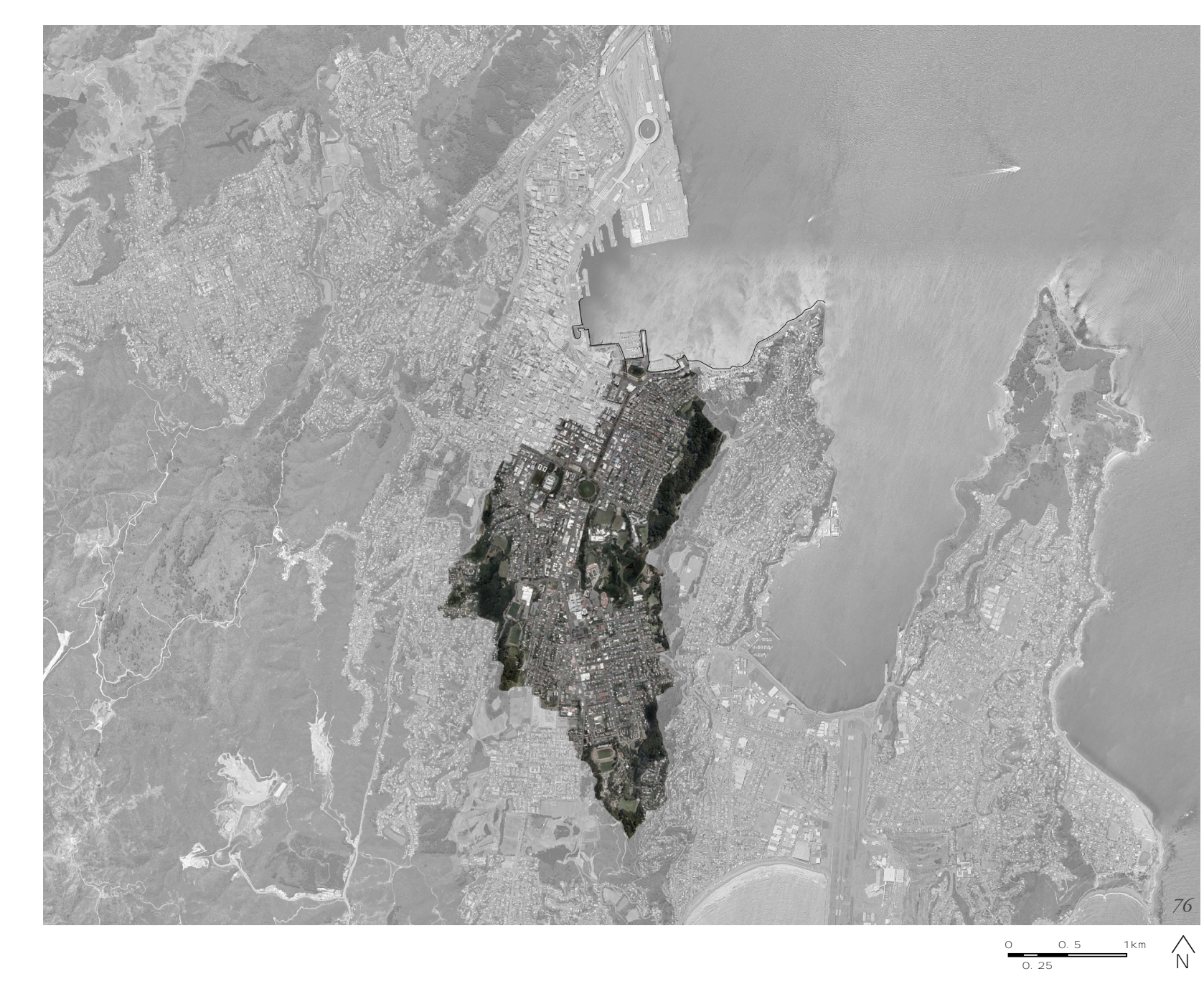

3.1.1 Stormwater Issues in Wellington

In today's uncertain context of looming climate change and natural disasters in Wellington where "the only main road out of the city", government house, the main shipping terminal and 80 per cent of the water supply are situated right over a major fault line provision of
water supply and runoff after a natural disaster will be a critical issue. ${ }^{100}$ In the early years of the settlement of Wellington a city which is "tightly wedged between a steep cliff and a waterfront built on shaky ground", water was mainly obtained from urban streams, springs, shallow wells or rainwater tanks. In an attempt to improve the health of the city these have been culverted and led into stormwater drains. ${ }^{10}$

The Wellington stormwater network consists of nearly 650 kilometres of pipes between one and 130 years old, which convey "almost 80 illion cobic metres of Co Com does not meet this design stand Flooding of properties, buildings and land, along with "pollution of receiving waters and the environment from contaminants in Concil when analysing the current state of the stormwater system. ${ }^{\circ 5}$ W

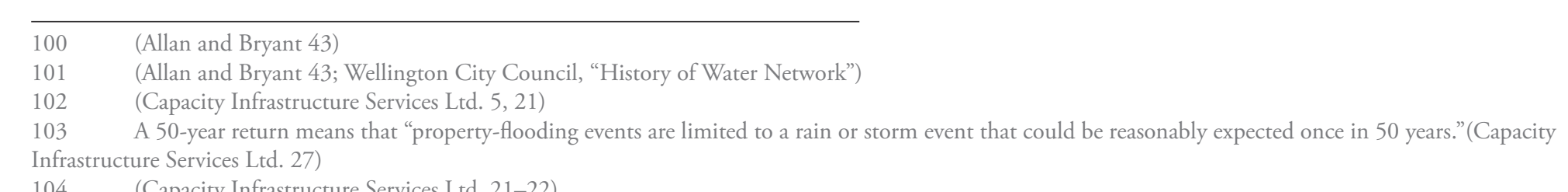

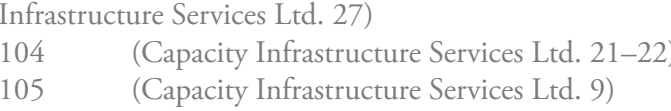


amount of impervious surfaces intensifying with the increasing population and rise of development the amount of surface run-off during storm events also increases resulting in "increased pressure on undersized pipes" in turn causing "overland flood-flow and general flooding". ${ }^{106}$ While the current stormwater system is becoming increasingly inadequate in coping with storm events it is predicted that due to climate change the frequency of these large storms will only increase adversely impacting on the flooding problem. ${ }^{107}$ Storm events are not the only issue facing the stormwater system with climate change also predicting sea level rise. Storm water outlets already become drowned at high and storm tides especially areas such as Kilbirnie, Miramar, Seatoun and some parts of the CBD. ${ }^{108}$

The receiving waters quality is a big issue also with road runoff containing "contaminants from vehicles [such as] (zinc, copper and alumiosilicates from types and brakes of vehicles and sulphur from the fuel)" as well as being "heavily influenced by surrounding
landuse $\ldots$ and activities "resulting in the Wellington and Porirua Harbours containing ecotoxic ${ }^{109}$ contaminants "at concentrations landuse $\ldots$.. and activities "resulting in the Wellington and Porirua Harbours containing ecotoxic ${ }^{109}$ contaminants "at concentrations
that exceed guidelines for aquatic life." 10 Inflow and infiltration between the stormwater and wastewater networks also affects the that exceed guidelines for aquatic life. Infow and infiltration between the stormwater and wastewater networks also affects the
stormwater discharge quality, with this being a significant problem in "older areas of the city, especially in the CBD (central business stormwater discharge quality, with this being a signifif
district) through to Hospital Road in Newtown." 111

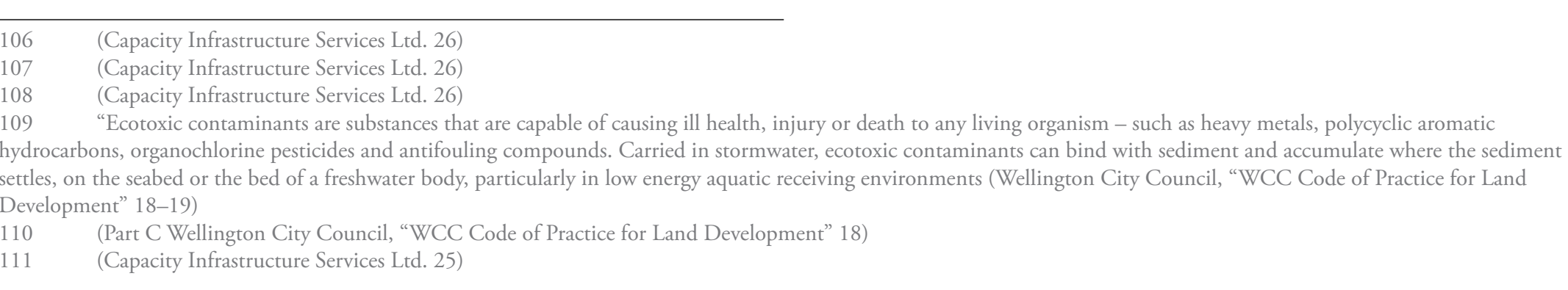




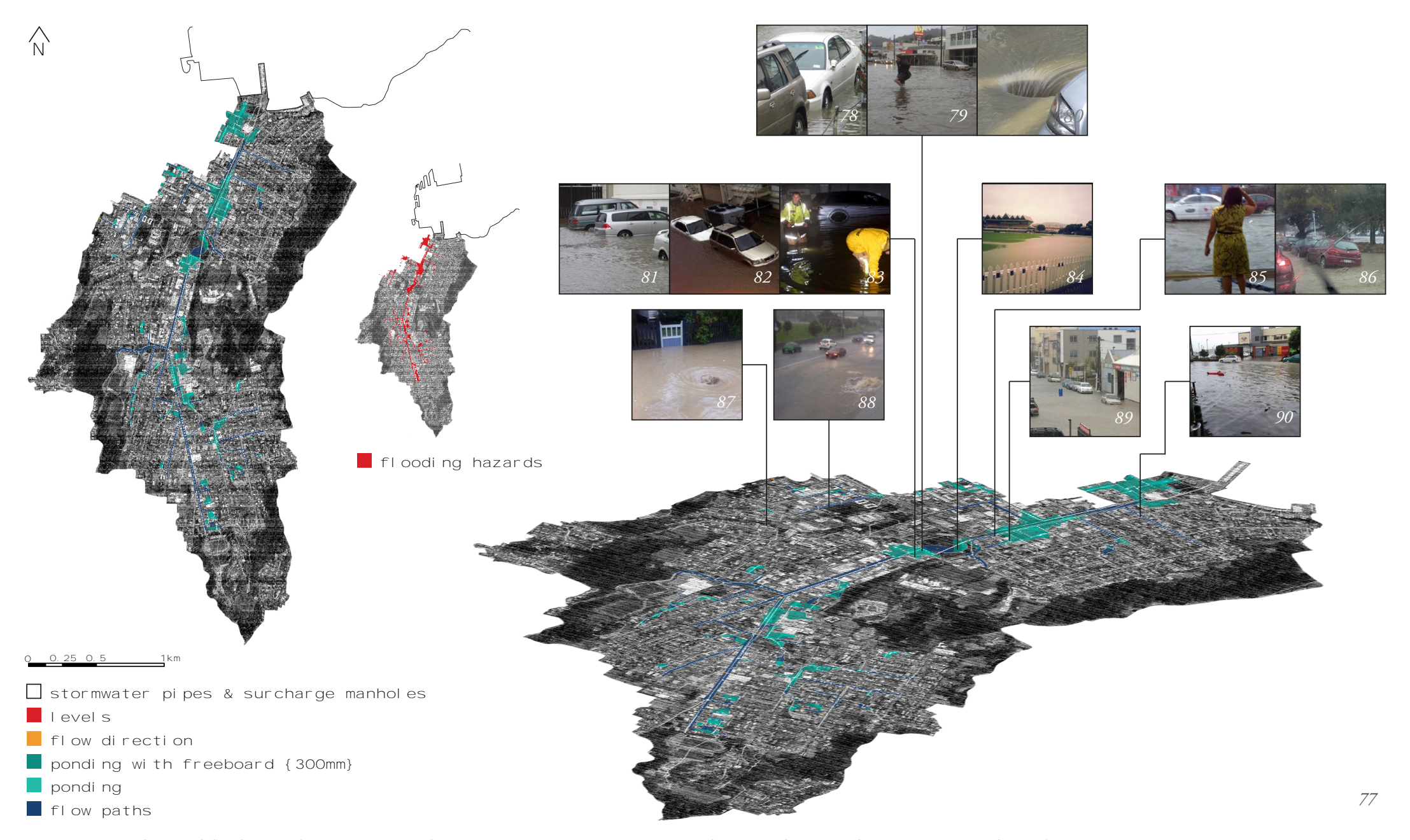

3.1.2 Flooding versus Water Quality

While it would be fascinating to deal with both the quantity and quality of the stormwater, my limited knowledge of stormwater infrastructure and landscape architecture meant that this would not be feasible. Instead, I chose to focus purely on the quantity aspect. higure 77 shows the ponding and flooding hazards based on a one in 50 year storm event in the chosen Newtown catchment, along with the flow paths and directions and the ponding with a freeboard ${ }^{112}$ of $300 \mathrm{~mm}$. ${ }^{.15}$ Alongside this map are contextual photos from storm event in the beginning of May 2013, when a considerable amount of flooding occurred throughout the Newtown catchment articulating the current stress the stormwater system is under. Through analysing this flood hazard data alongside another flood hazard study from SKM of the neighbouring Taranali catchment it became clear that controlling the stormwater in the upper areas the quality of the stormwater outflows. The council suggests that "permeable or porous paving, and retention and detention devices may be effective means for controlling peak flows of road runoff by capturing the runoff and releasing "it at slow rates to filter out contaminants at source" allowing "suspended solids to settle, and in some instances, runoff to be absorbed (infiltrate) through to the ground, thereby reducing the risk of flooding." ${ }^{\prime 14}$ Using these concepts seems a far more practical and interesting solution to flooding, rather than attempting to flood proof the city by using "partial flood bypassing in pressure pipes, raising houses or disestablishing floodable areas" or relying on "stormwater pumping station", and means that the water cyclell15 in the city can be returned as closely 



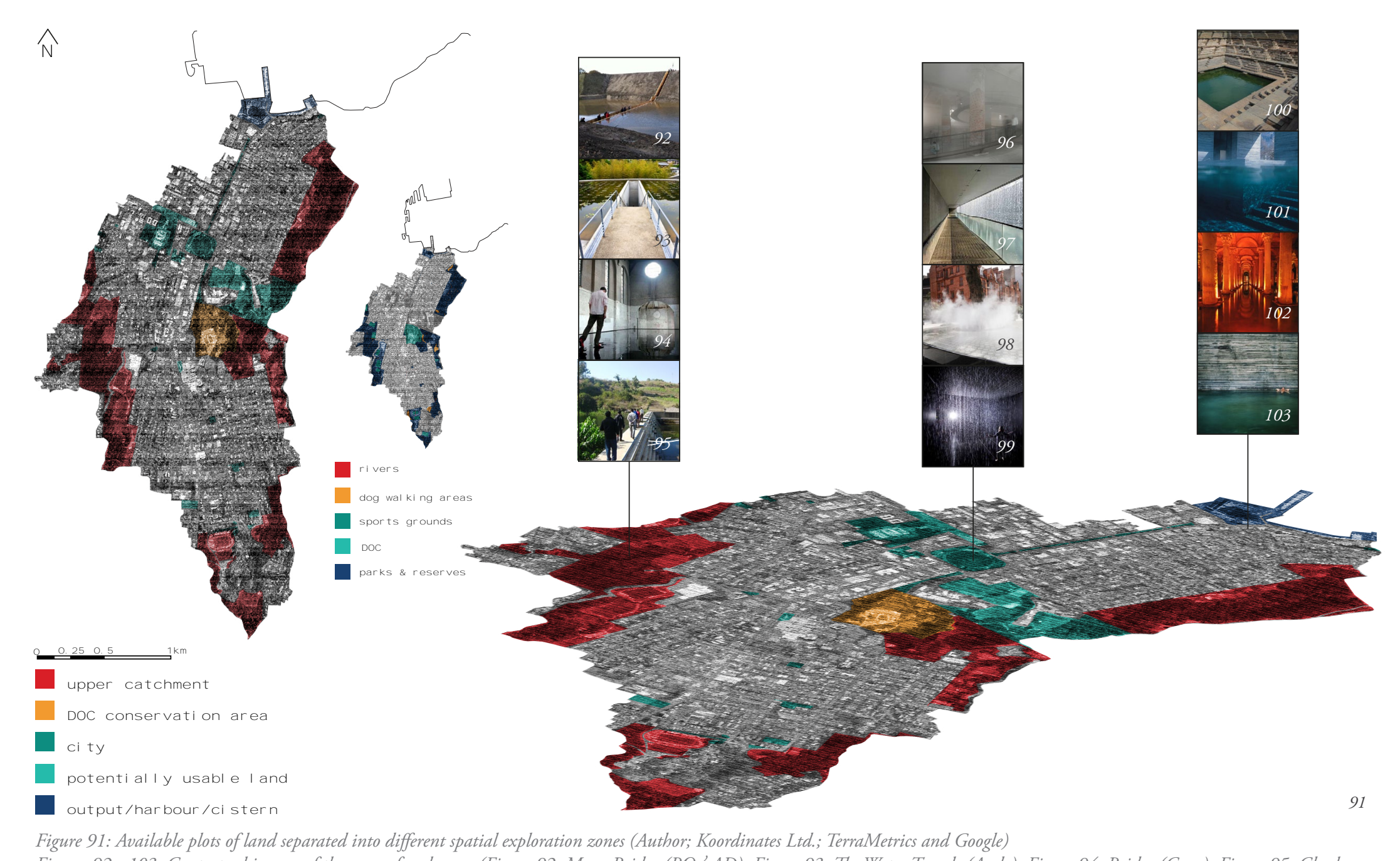

3.1.3 Newtown Catchment and Mount Victoria

Initially, I believed that I could tackle the entire catchment in a design sense when selecting potential areas for developing this design investigation in the Newtown catchment. I separated all of the available areas into 4 categories - the upper catchment, the city/ middle catchment, the output/lower catchment and Department of Conservation areas (which would in practice be unusable). I then associated the different areas with different design qualities with the upper catchment being linked to water detention, the middle catchment being linked to the different manifestations of water and temporal spatial experiences, and the lower catchment/output being linked to the concept of an underground cistern to store treated water, as can be seen in figure 91 . It quickly became apparent that although each of these spaces and qualities had huge potential, it was unrealistic to tackle such a large area and the implementation of all of these qualities through these spaces might not work for this project. This led me to reassess which areas I was going to tackle and how all of these spatial qualities might be involved in the design of a more specific area.

After analysing the Newtown catchment for some time, I decided to approach Mount Victoria as a site to explore the qualities of existential intimacy. After already identifying Mount Victoria as a site to test water detention, the design output began to become more aligned to the original concept of creating existential intimacy in relation to stormwater desigg 


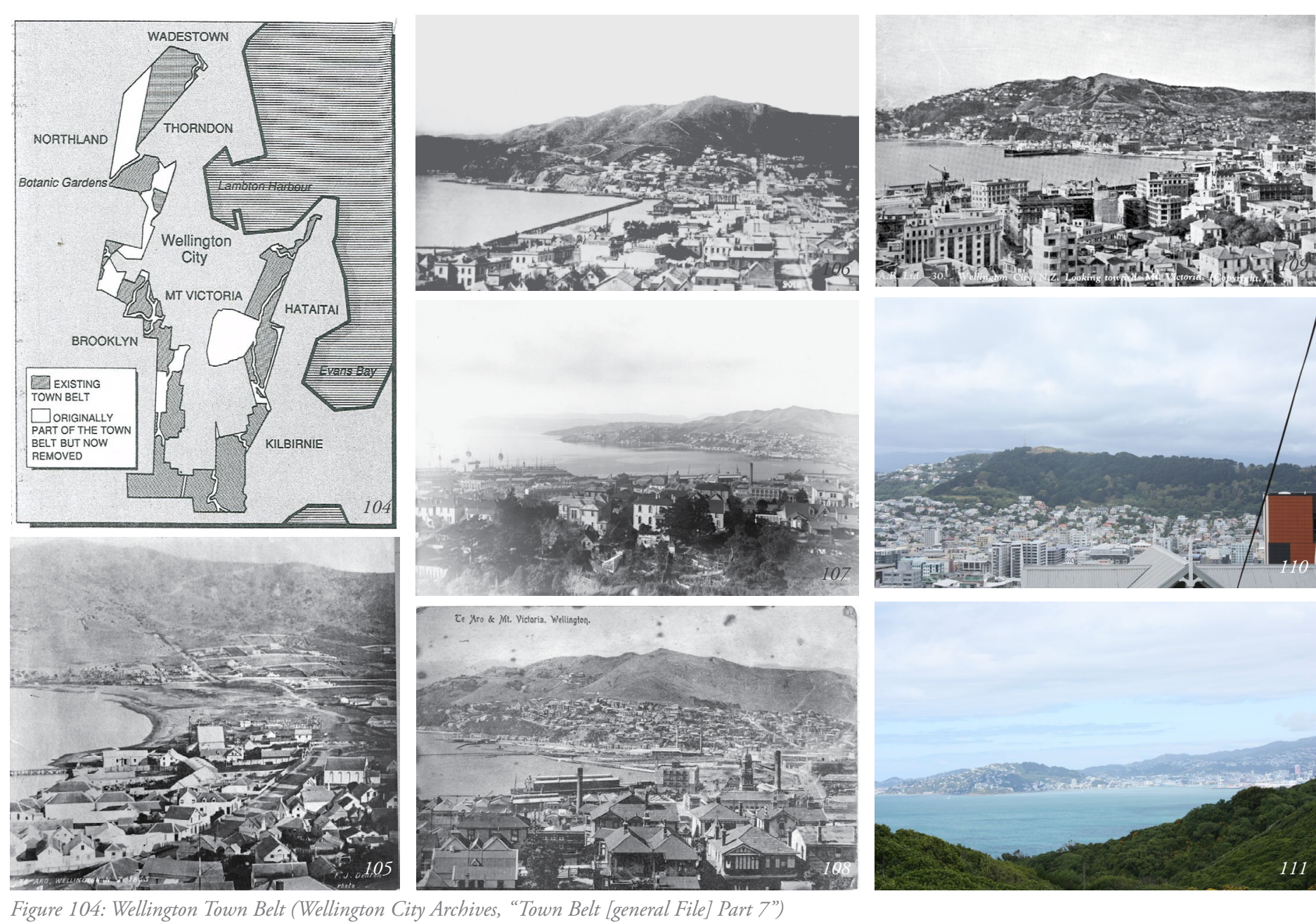

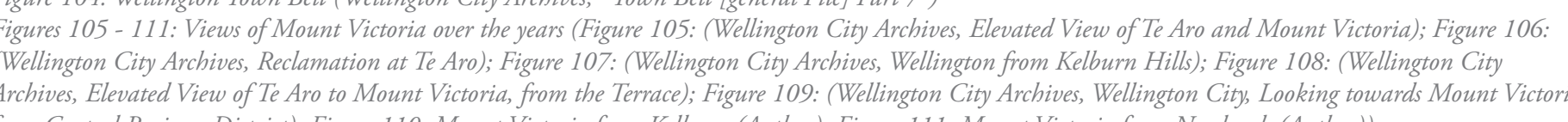

3.1.4 Mount Victoria and the Green Belt

Mount Victoria lies within the Wellington town belt, a green belt comprising of 393 hectares (in between 1987-1990), shrinking from the 615 hectares that was planned and set aside by the town planners in Britain and the New Zealand Company in 1839. ${ }^{117}$ The town belt itself cradles Wellington in a horseshoe shape, stretching around the CBD from Wadestown, Northland and Thorndon, back down through Newtown and Berhampore, and around to Oriental Bay (see figure 104). In 1873, a "Deed of Conveyance ... formally vested the belt in the city" stating that the town belt was "to be forever hereafter used and appropriated as public recreation ground for the inhabitants of the City of Wellington", a sentiment that has been strongly maintained by the people of Wellington. ${ }^{118}$

Mount Victoria has long held an important visual and recreational position in the Wellington CBD with the series of histori photos (n) be When visiting Mount Victoria and walking through its many winding walkways it is quite an amazing space. Making you feel isolated from the city while still being so connected through the bursts of traffic noise that cut through the birds and the wind and also a visual connection where the trees open up. The interface between the city and Mount Victoria is somewhat troubled however, with most pathways and entrances not giving any sign of the extroordinary spaces that are hidden behind the facade of trees. When I visited Mount Victoria and began to search for sites that might work with this concept of exisential intimacy it become rellly clear that there Wus

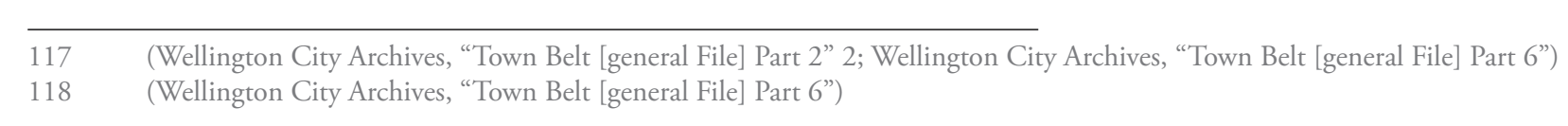




$$
1=
$$


3.2 Design Objectives

The method of enquiry into how this concept of existential intimacy and stormwater design can combine together within the landscape is through the means of water detention. Water detention up Mount Victoria opens up a range of possibilities in terms of how this usually process focused design can become more experiential and evoke a sense of understanding or context. I have tested this concept through designing dams and other detention structures up Mount Victoria, to see what the context and this functional aspect can draw together. Instead of just allowing existential intimacy to occur, the space will be intentionally crafted with the detention structures and use of water to enhance the space and its qualities. By specifically designing in the context of Mount Victoria, allowed physical site visits which aid in drawing out the specific spatial qualities of the experience relevant to this location and it allowed a greater sense of connection. By engaging in this practical way with water it also means that the spaces will have multiple levels of meaning and will enhance the connection between people and space. By designing in this context, it means that an expansiveness across scales will be created and dealt with meaning the details cannot be lost. However for the space to be successul it also has to be connected to the whole context. 
By using design as the primary mode of enquiry throughout this research, the concept of existential intimacy has been teased out and understood in more depth. Only through analysing and designing spaces in Mount Victoria and others which I had physically visited was I able to understand that existential intimacy is about the coming together (assemblage) of concepts, experiences and spaces resulting in rich, experiential spaces and spatial experiences. I learnt through the design development that some representations ant explorations of existential intimacy were too subtle and needed a stronger intention and spatial effect to fully encompass this concept of existential intimacy. By using water detention as an articulation of this enquiry it has meant that the design goes from being purely poetic and temporal to having an everyday functional use and need. Developing the "art" of existential intimacy has been a huge challenge specifically in relation to mewledge at the beginning of this research. Through testing of theoretical concepts from architects such as Juhani Pallasmaa and Gaston Bachelard, and interrogating case studies a combination of theories and representations has evolved. As a designer I tend to get stuck in the details of a design slowing the progress of the overall design. However by designing with this concept of existential intimacy 1 have been forced to look at the spatial details in conjunction with the overall larger context of the design and its implications. 
Working within the interface between Landscape and Interior Architecture has been one of the main challenges throughout this research. How does one deal with the small details and design evocatively while also considering the entire larger context and drawing these details at a different scale? This interface is one that not many have braved to dabble in but through this concept of existential intimacy the two somewhat disparate disciplines are drawn together in a harmonious way to encompass all the spatial experiences related. Not only this how does one communicate these ideas not only visually, but also verbally? Each discipline has its own set of language in drawings and language, as well as a specific style. I came into this research believing interior was better at representing spaces than landscape but through testing and designing have found they represent in different ways with interior being based in the perspective
and landscape based in the plan and section.

Working in this interface has resulted in huge growth for me as a designer as it has pushed my skills and knowledge to my limits while also allowing me to interrogate my own discipline and its relationship to other disciplines. A really important and interesting challenge that showed up throughout this process as well is that interior architecture is extremely digitally based focusing a lot on digital renders and building space in the 3 Dimensional perspective whereas landscape tends to be based more in plans and sections. It has been an interesting challenge using both of these typical forms of representations but perhaps the most interesting and surprising thing was that for the majority of the representations throughout this design a lot of it was done through hand sketching and drawing which was then enhed and he have the same knowledge and understanding of how to articulate in their way and I have a very different way of seeing space and 
understanding it in drawings. For instance, the large cross sections in the body of the design were a set of drawings that took me a long time to craft and master as I was trying to maintain the balance between the spatial feel for the section along with the ecology and typography of the space to create a drawing that read to me as more than just a diagram. I found comfort in creating spatial perspectives but found that these often werent' as meaningful in communication as the cross sections and plans were.

The interface between these two disciplines has so much untapped potential with both being able to connect and communicate across many levels of understanding and representation. I think the most important aspect of the relationship between these two disciplines is the different way they connect to site and context and what that means for the design - generally interiors are very insular and don't relate well to site and context and landscape is usually so caught up in the site that the smaller spatial details are lost. It was a really interesting challenge connecting and communicating ideas with people who have a slightly different thought process and way of articulating this. 
In order to deal with the engineering aspects of this design, I had to tap into a lot of other professional knowledge and experience to provide the general idea and concept of what I was trying to achieve. For the context of this research it was not important for me to learn absolutely everything about engineering, stormwater design and water catchments but to learn enough in order to help progress the design. This involved learning how to do and to use ArcGIS mapping tools, learning about the general concepts of landscape engineering - particularly in relation to stormwater, check dams, larger scale dams and water sensitive urban design - along with how to work out peak flows of catchments and pond capacity calculations. All of these meant that the design tended to take a more practical route through these calculations and explorations and I often found myself getting caught up in trying to understand and implement these concepts. Over the year I found myself understanding these concepts far quicker and easier than at the start. 
3.3.3 Preoccupations

In general throughout this research, I have tended to be preoccupied with understanding and implementing all of the technical engineering and landscape information. I have spent a lot of time learning and understanding the theoretical side of engineering, stormwater design, stormwater management and the issues in Wellington city. Ialso spent a lot of time trying to understand the history of the site and the context, resulting in many hours at archives.

I began by interrogating what it was that I meant by "intimacy" teasing it out into a more comprehensive concept, analysing sites and case studies, doing site visits, drawing design drawings (such as plans, cross sections, perspectives, details), going back and interrogating these drawing a a process getting the technical and functional details correct was a big focus and probably distracted me from the actual point of my
design - the concept of existential intimacy.

This research contributes to not only the field of interior architecture, but also landscape and stormwater engineering. It opens up possibilities for experiences of spaces that currently tend to process and function driven while pushing the boundaries of what interior is and developing a more comprehensive representational language for landscape. Generally the biggest thing I struggled with throughout this process was the representation of this spatial quality in a landscape format. 
The following design explorations present a series of opportunities and explorations in terms of how this design could work in context.

It is probable that at this scale, context and time there is not one final design that could be selected and implemented. Rather the range

of possibilities presented have the opportunity with refinement through the addition of other disciplines such as engineering to becom

a relevant choice. The presented designs represent a selection of different detention systems- interestingly a variety tend to occur across

each sectio 
3.4.1 Overall Contex

To begin tackling this large space size I was unaccustomed to I went on some site visits and then began to generate flow studies in Arc Map to figure out where the water tended to flow in storm events (see figure 119). From this I then looked at the flow paths and the contouring of the land and began to draw out areas that might hold decent amounts of waterf am wall was built. This turned out to be a crucial step in the design as the potential for this space became very clear once this initial drawing was done. From here I attempted to select a few of the detention areas that I believed would be the most efficient and create some interesting spatial experiences. I then tested with general rules, what the plan turned into when drawing straight dam walls, using the assumption that 1 metre in height meant 250 millimetres in thickness of the wall. Then testing with curved walls was the next step as a general rule is that the material thickness of a curved concrete dam wall is about half as thick as a straight wall. 


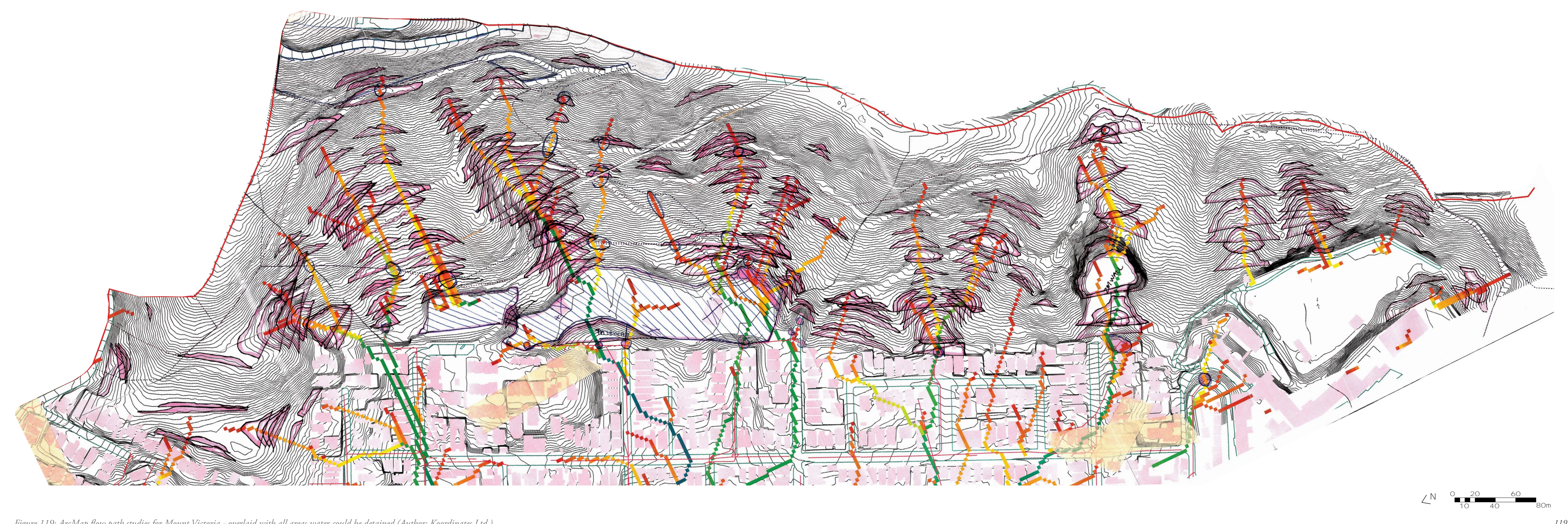




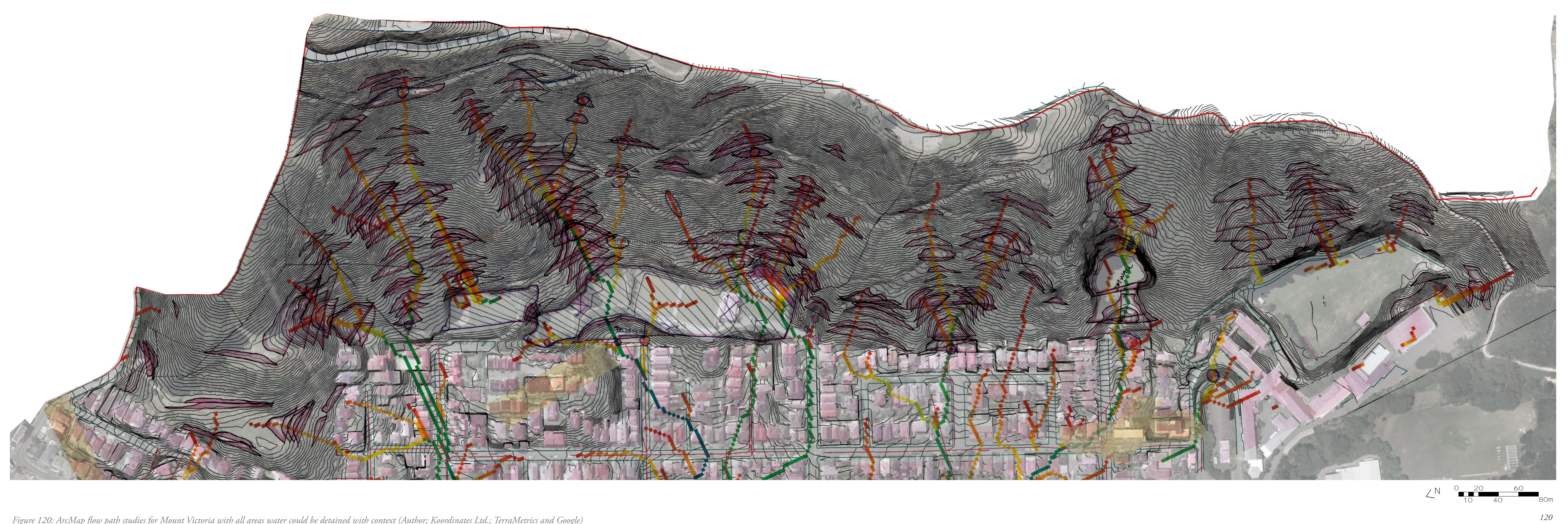




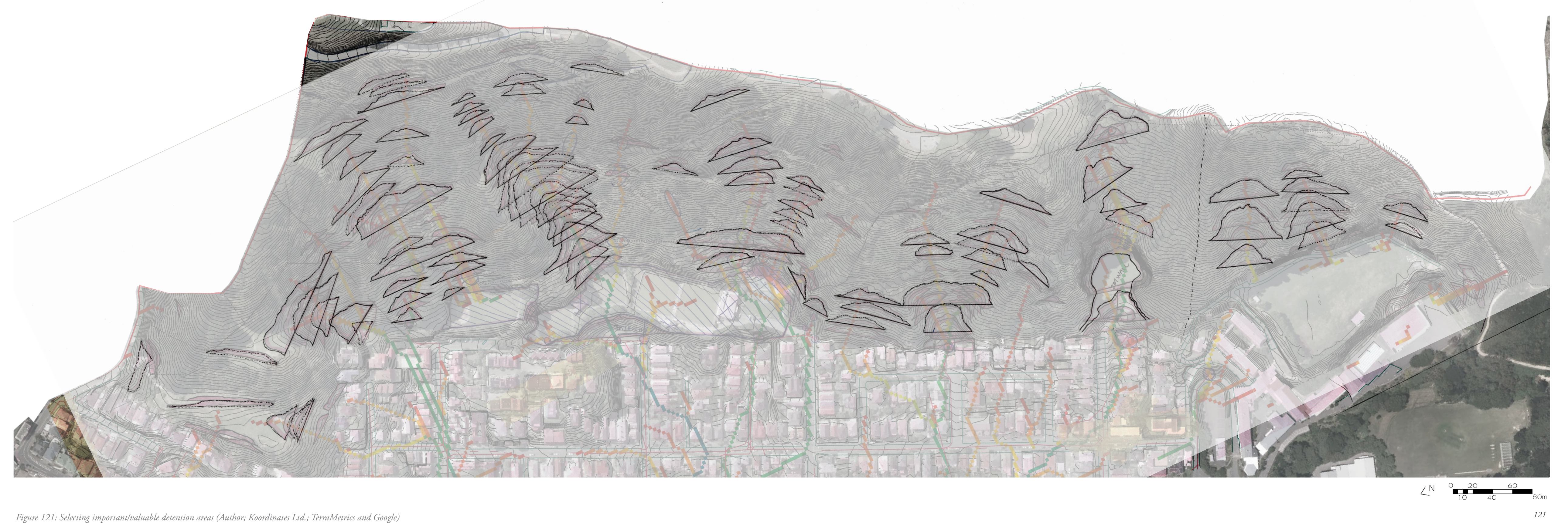




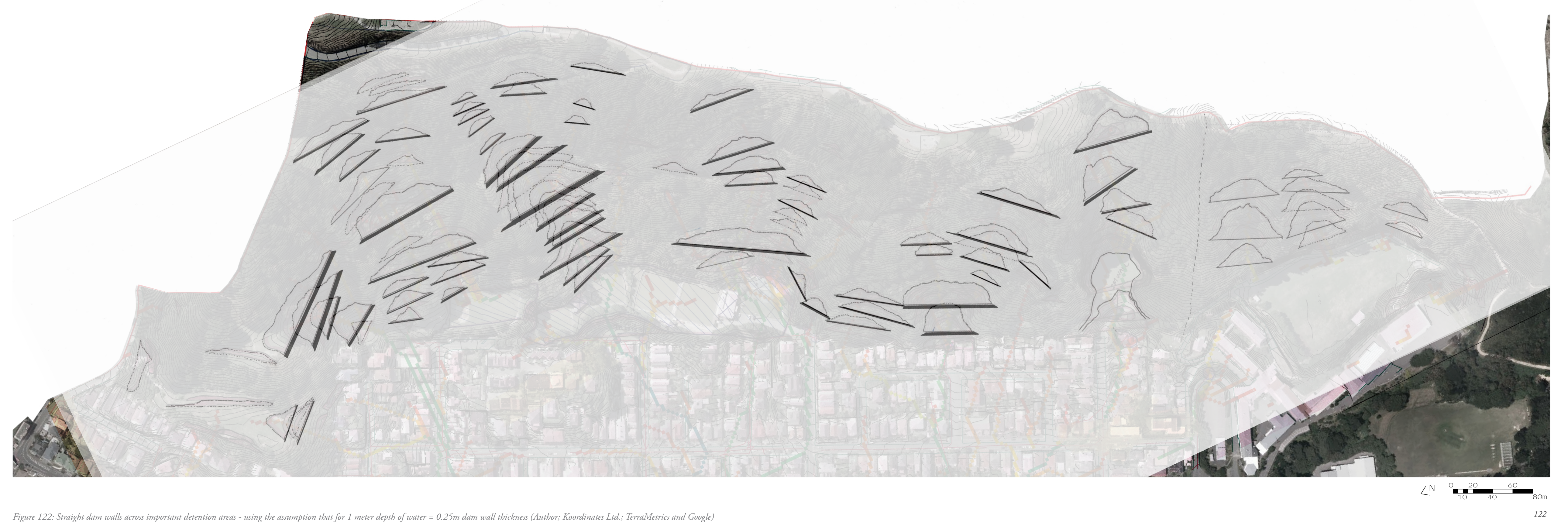




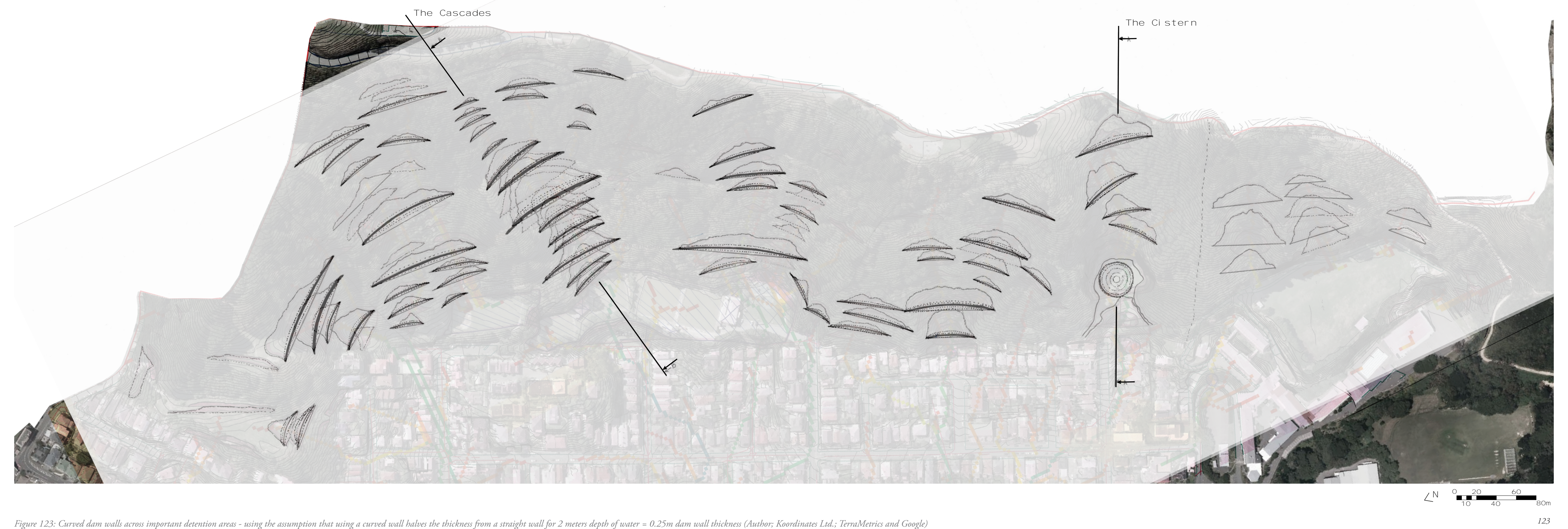




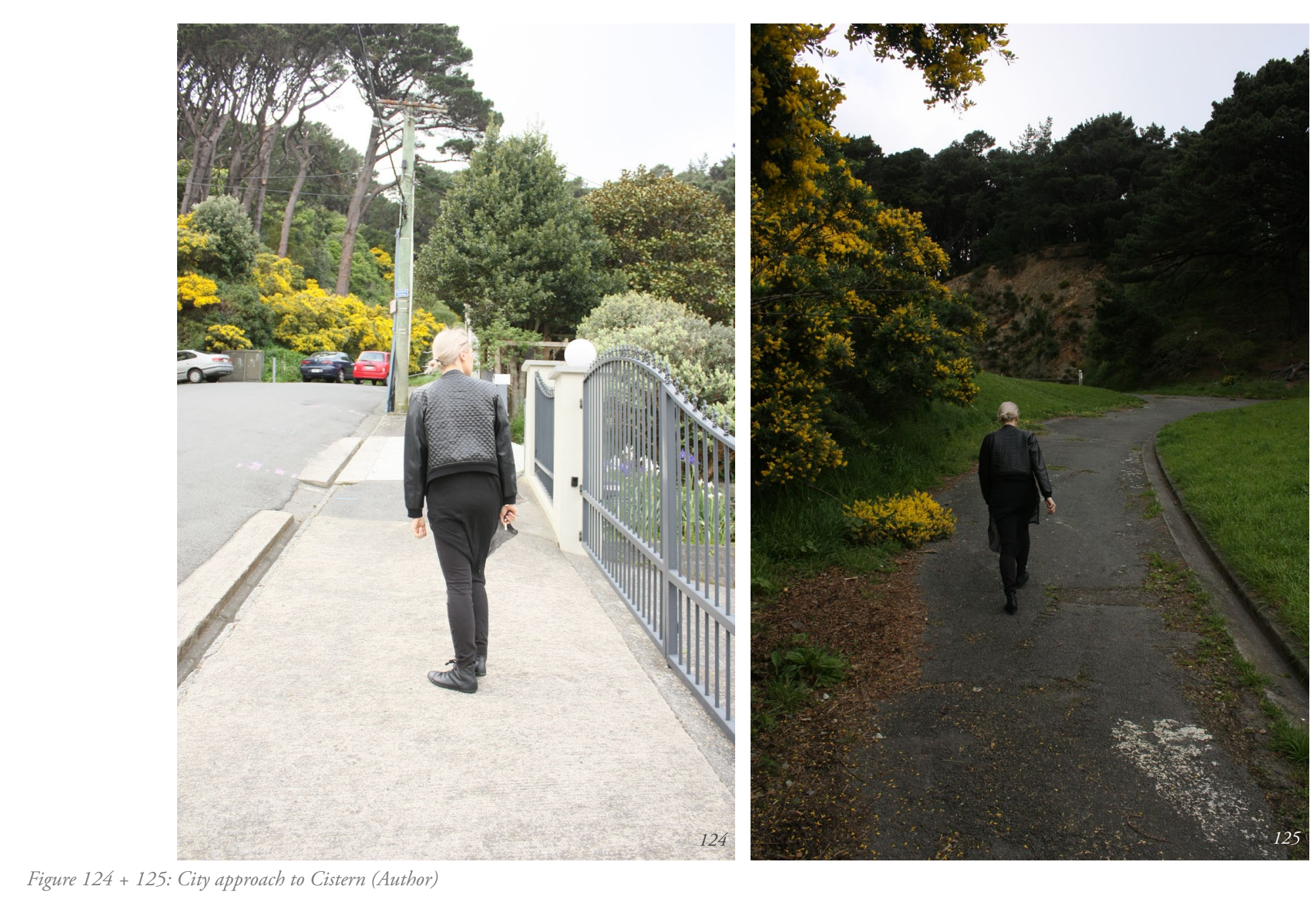

3.4.2 The Cistern - Abandoned Quarry

The Cistern is an old abandoned Blue Metal quarry at the top of Ellice Street. ${ }^{119}$ Over the years the space has been used as a dumping ground for rubbish, an area for shooting practice, and currently as a dog walking area. ${ }^{20}$ There is something really spectacular abou this space, particularly as there is no other space quite like it up Mount Victoria. Approaching the space, one must walk either up a steep hill from the city, or down a narrow path from the town belt but once you cross the threshold that is the hump of the hill you are cast into this deep bowl like space which opens out onto the city. As soon as you enter the space, you are confronted by the intense verticality and the height of the space, drawn towards the back of the quarry, and when you turn around you are rewarded with a sheltered view across the valley out towards the city - standing on the brink of the of the boundary between the city and the green belt. By adding water and an undaground cisten to the space, he bowl hike atmosphere is enhanced and the visitor disappears under the ground level to experience the cistern just out of site of the city. This space becomes a sort of catalyst for the rest of the design, acting as another form of detention. The tank works alongside the series of dams to help slow the flow of water into the city.

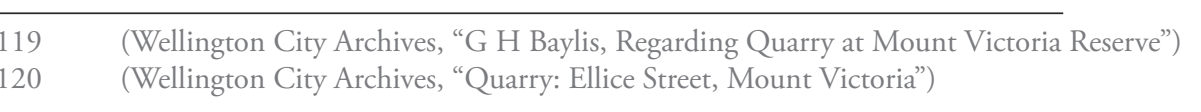




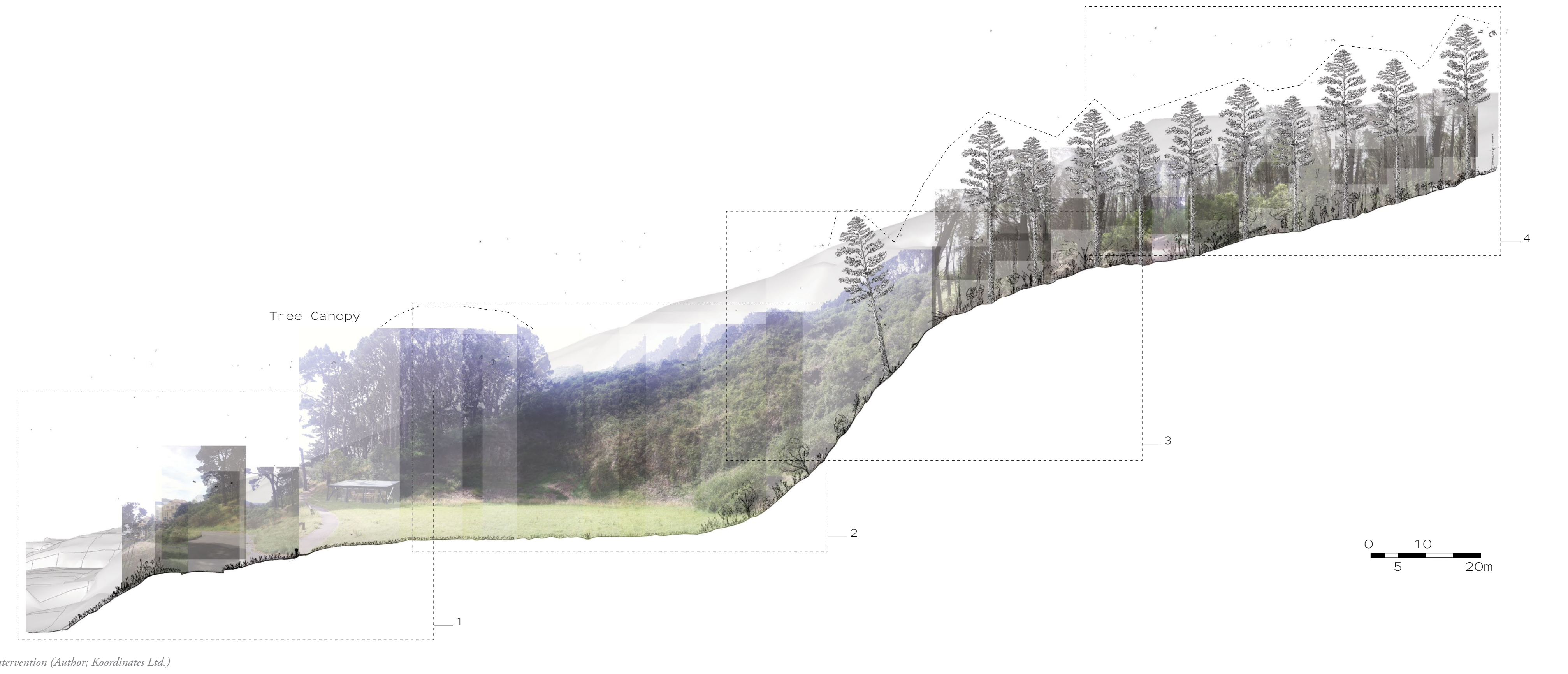



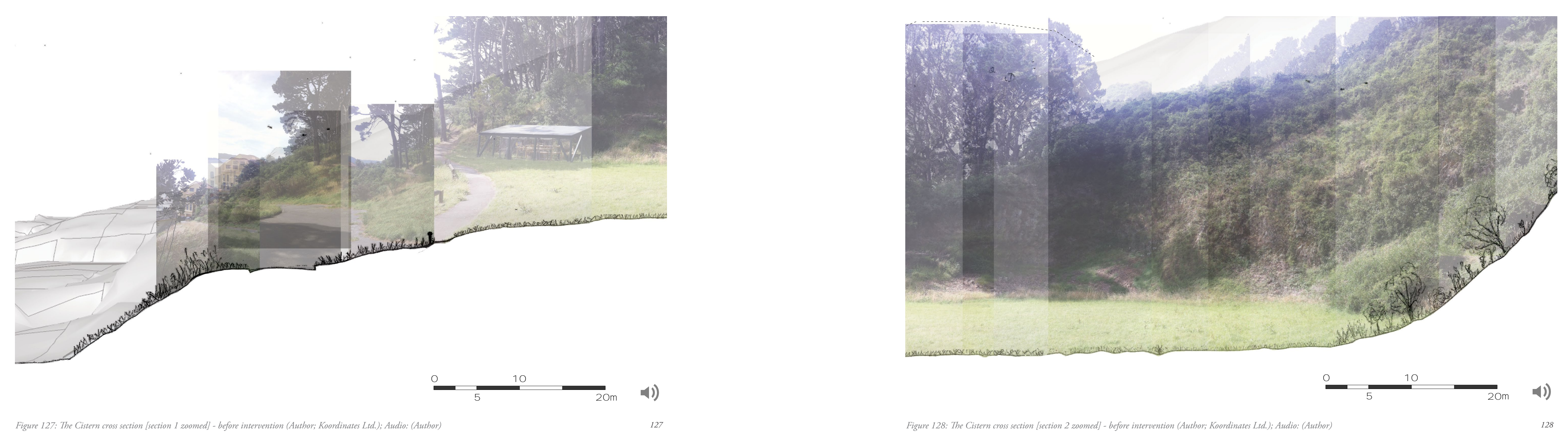

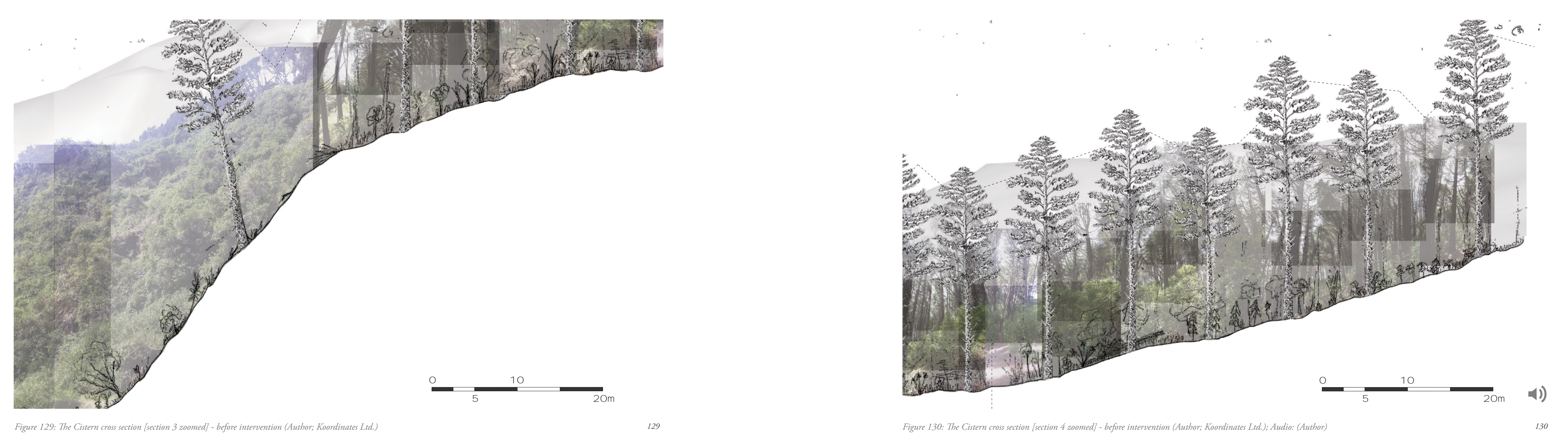

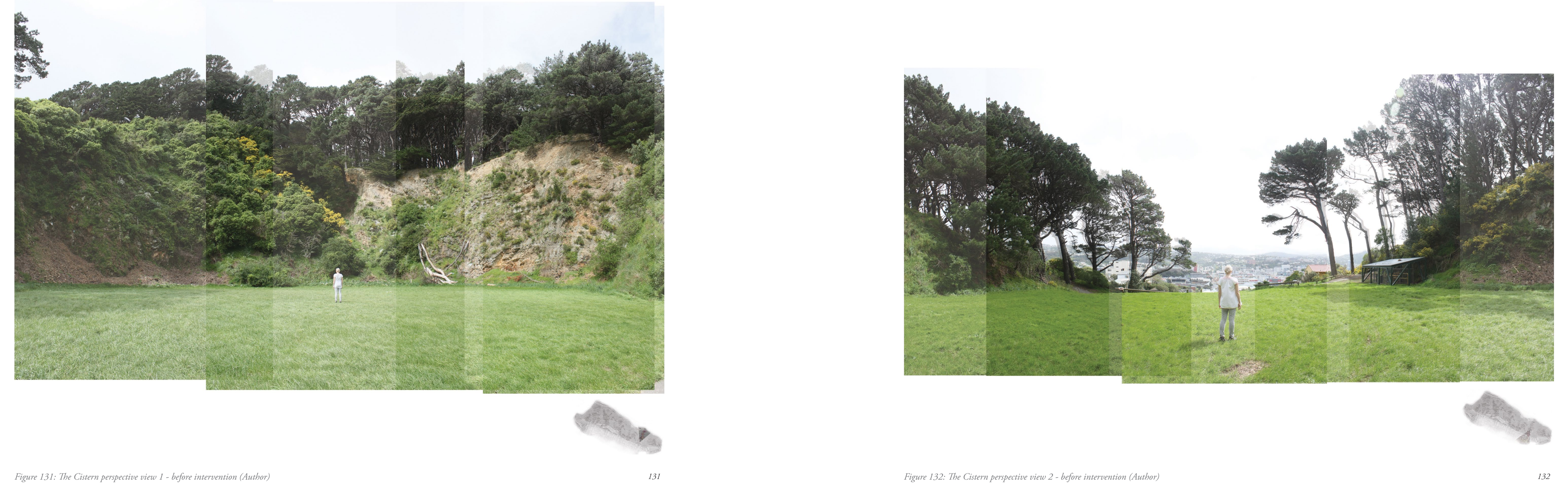


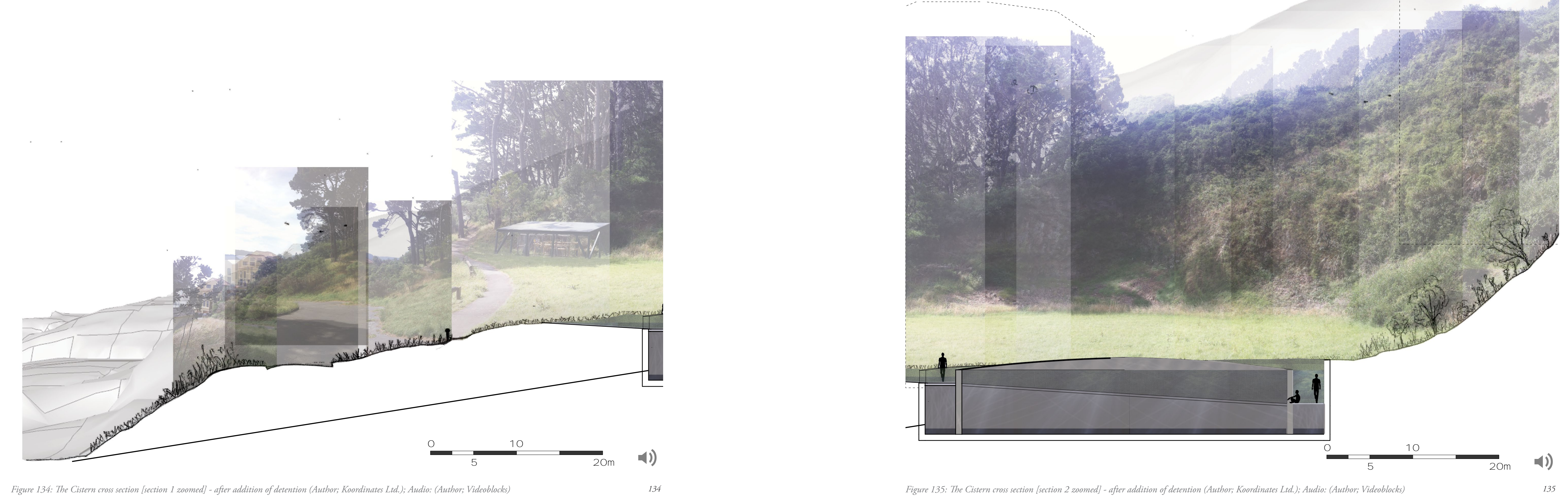

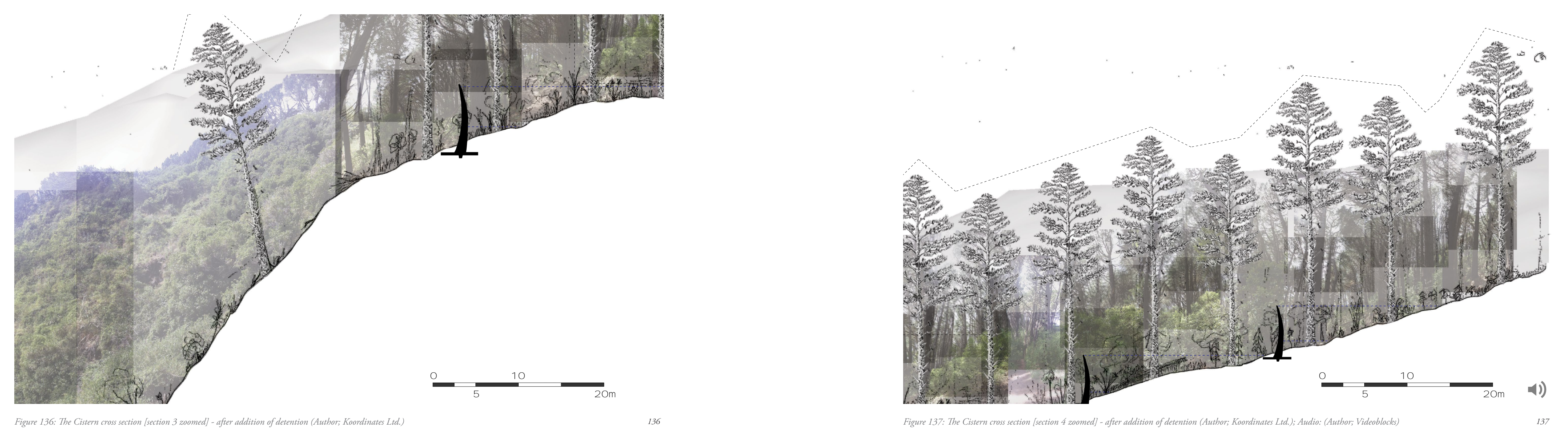

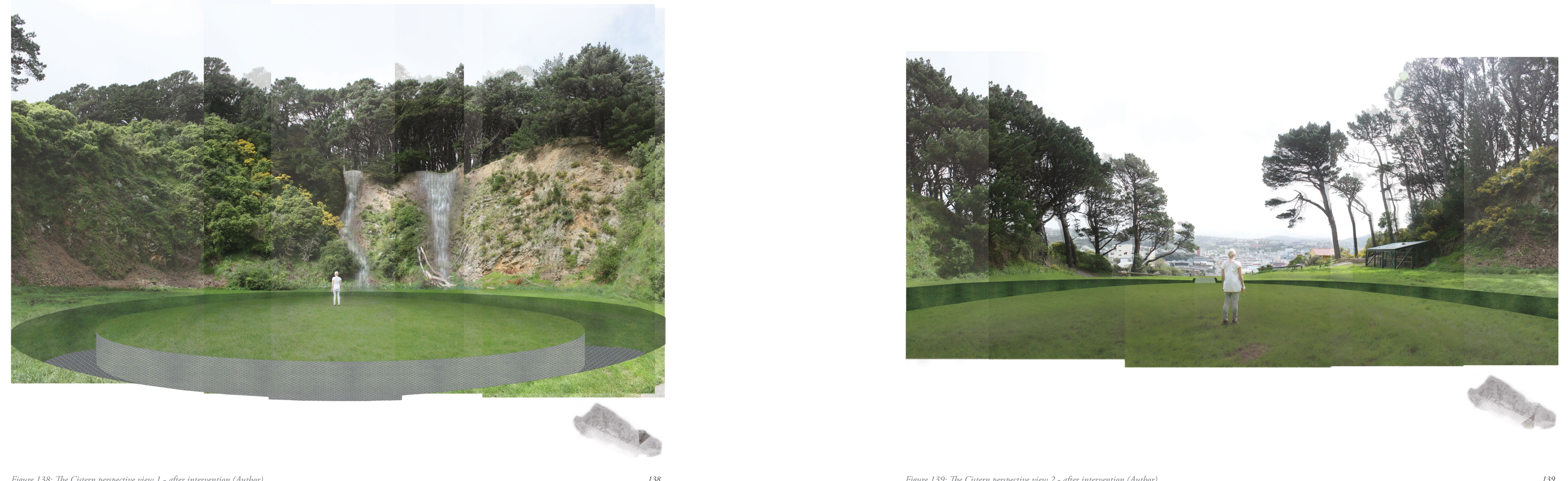


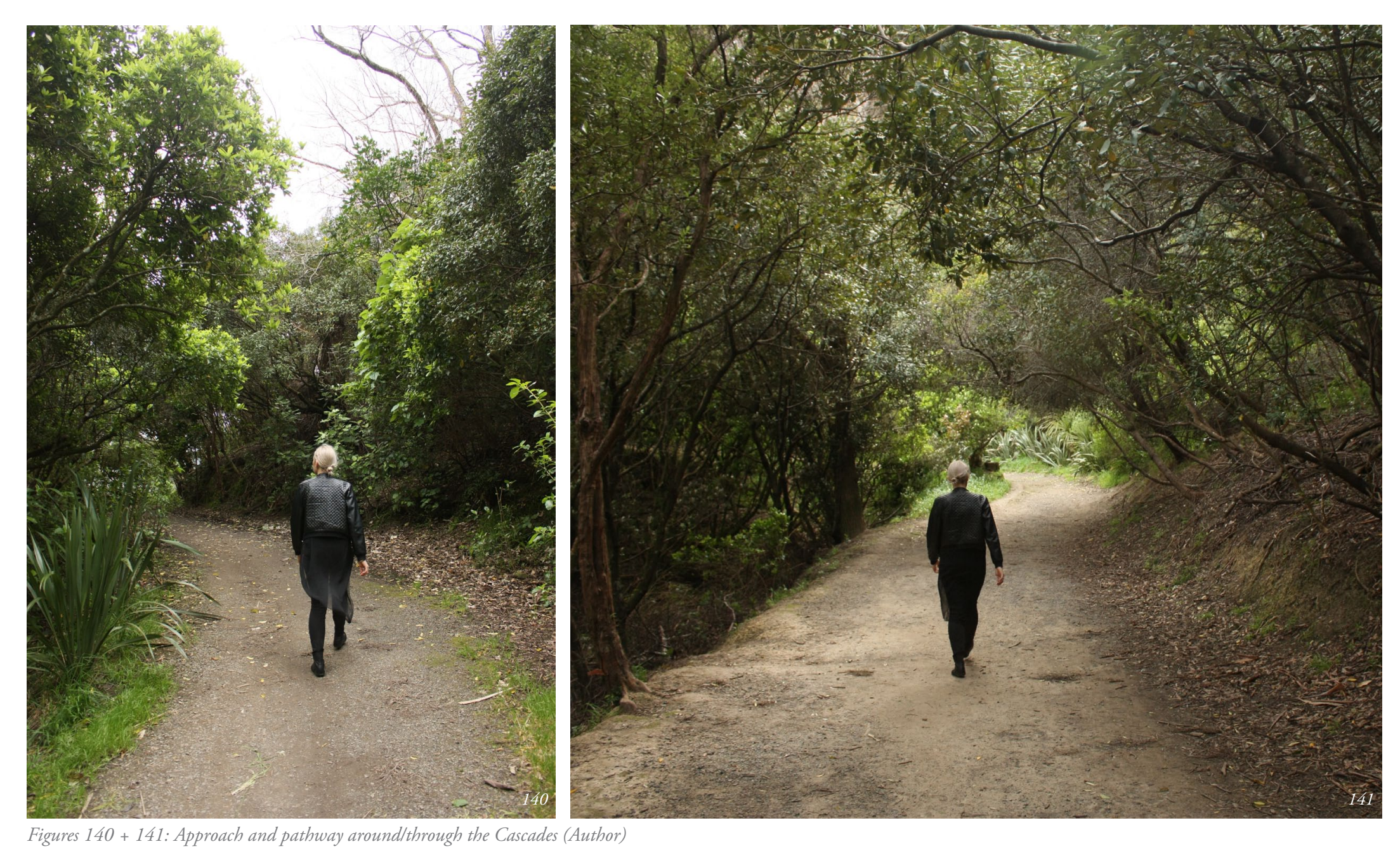

3.4.3 The Cascades

The Cascades is a series of spaces connected through overflowing check dams. This space runs from up near the Mount Victoria lookout down into the community gardens which occupy an old bowls turf. The cascades are the largest area of its kind on Mount Victoria and represents the large range of spatial experiences created through this design. The current paths wind their way around and through the gully, constantly winding their way up the hill. By adding this series of dams this site becomes slightly easier to navigate and opens up to the sky above. What is quite nice about this portion of Mount Victoria is the range of ecologies that one passes through, making it an ever changing experience particularly in regards to the level of enclosure, shade, height and scale of the space. With the addition of these dams comes the addition of the sound of Howing wate, making the experince of the space really unique. Depending on how full the ponds are the visitor will either hear and see water flowing, or see small ponds of water. The ponds always have a small amount of water in them to maintain their aesthetic appeal. The series of dams all range in scale and size, inviting different activities and experiences, some to cross and some to sit on 


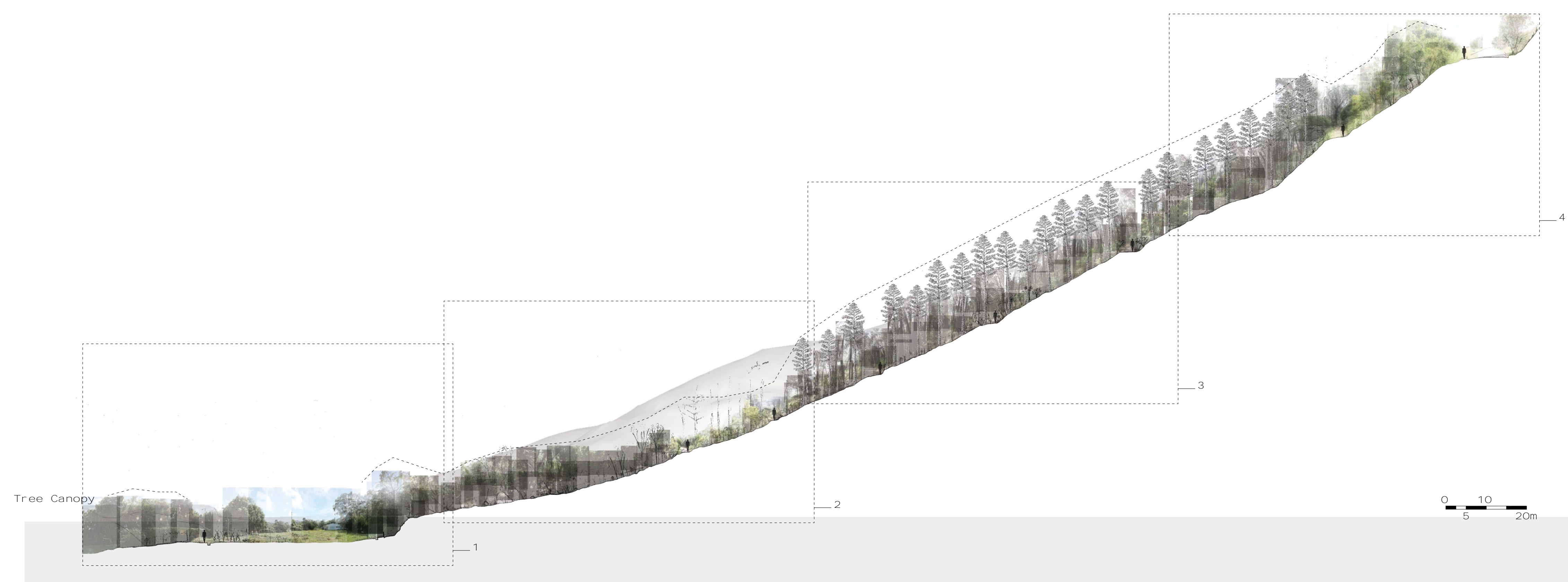



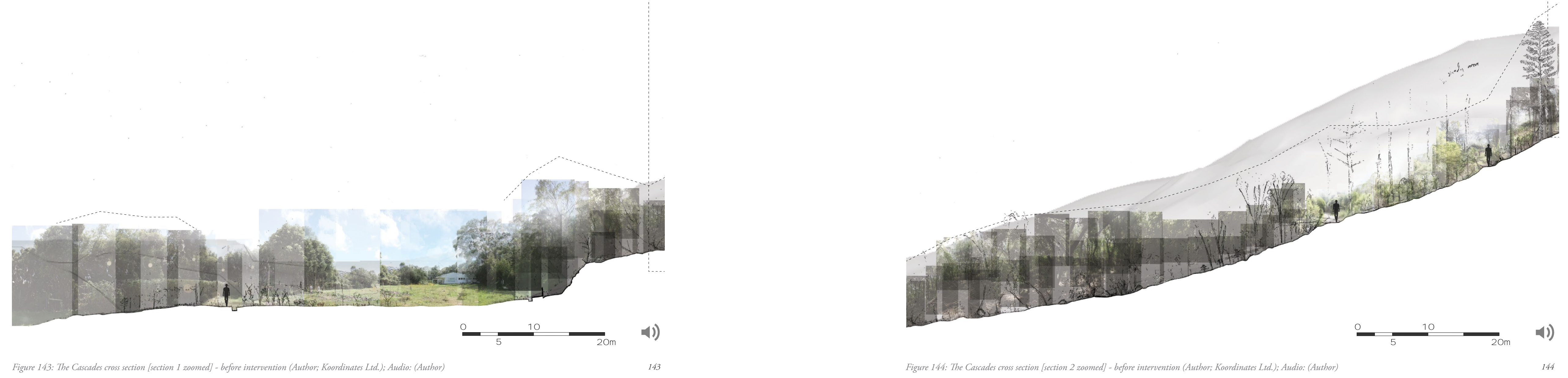

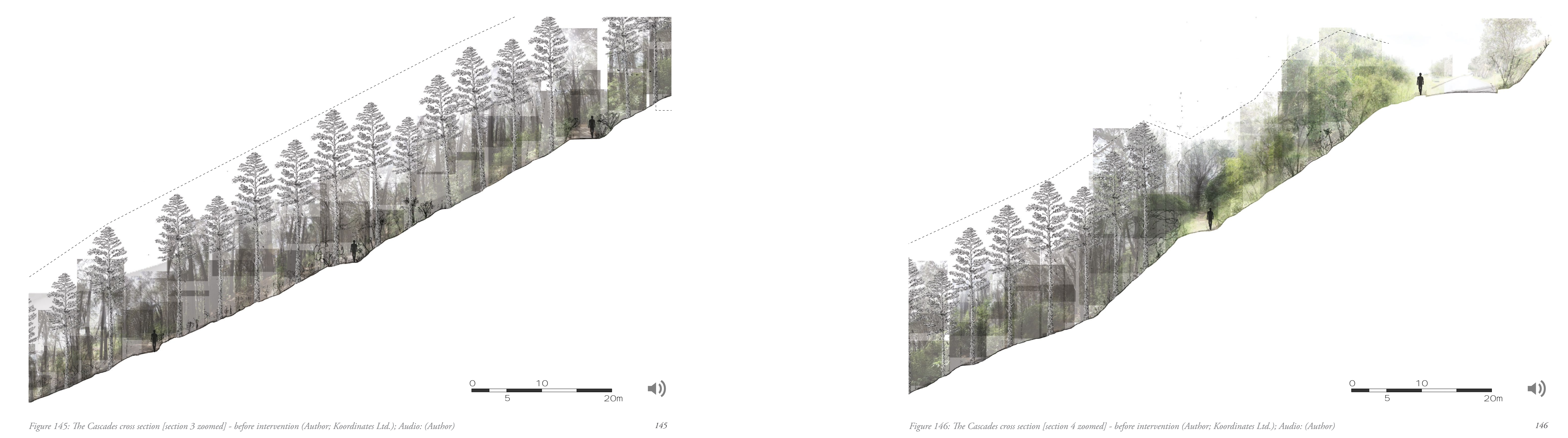


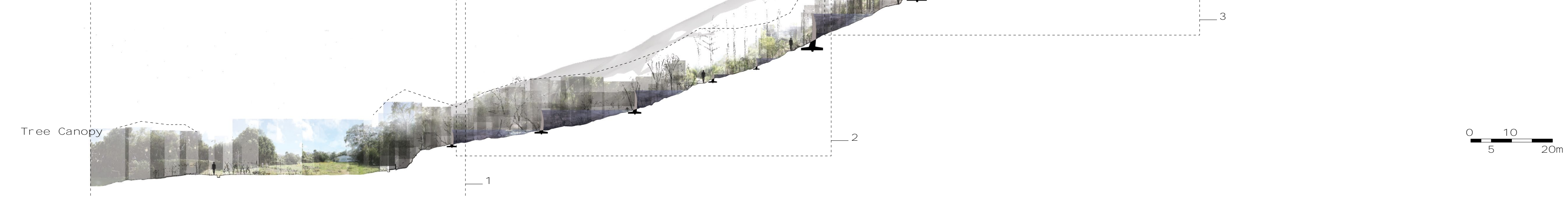



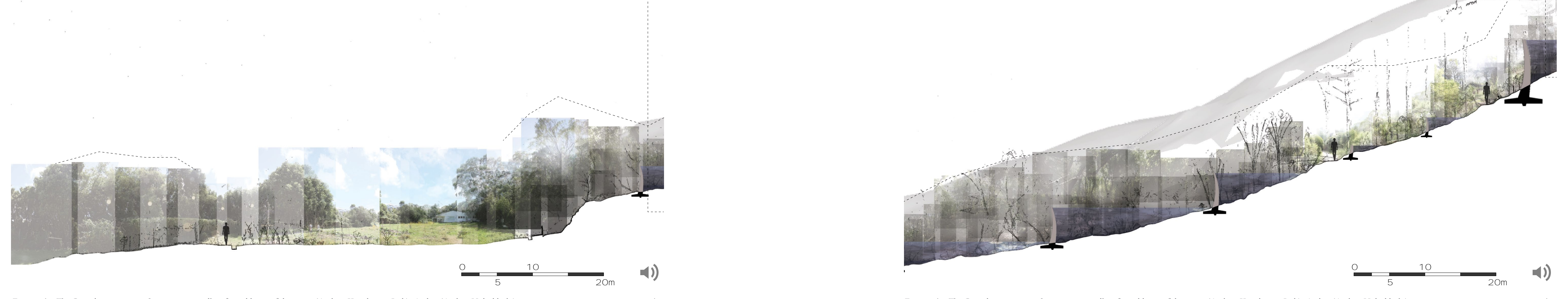

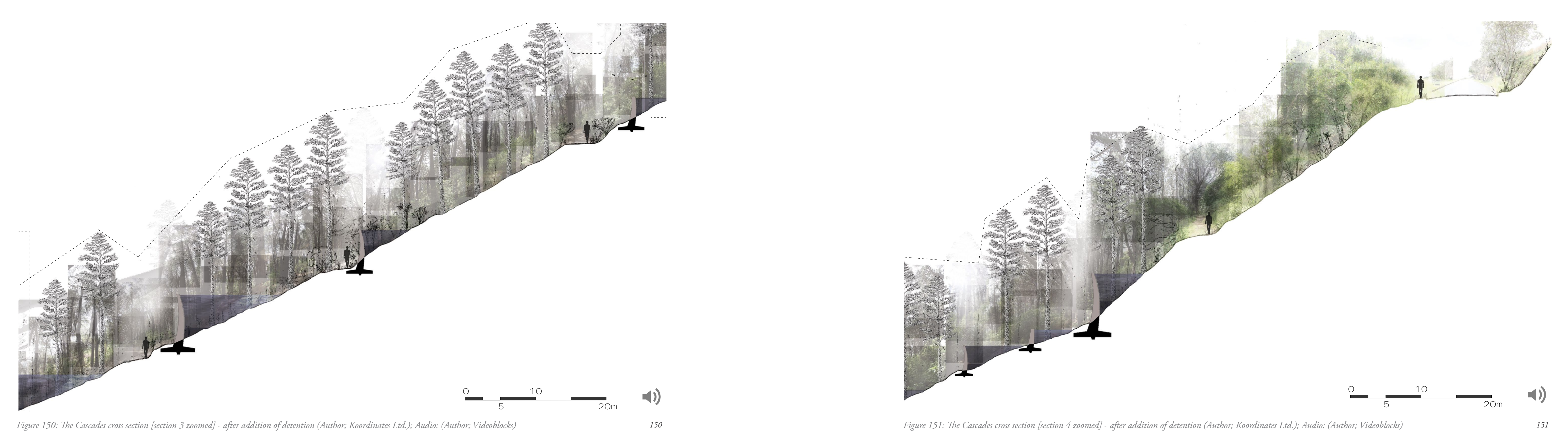
4.0 Discussion

This research thesis has been an interesting journey of discovery not only of where my skills, knowledge and abilities lie but also in exploring and understanding this concept of existential intimacy.

Throughout this research I have encountered challenges which have pushed my abilities and forced me to learn a lot. Among those discussed above the main ones I faced were how to use a range of media to represent existential intimacy - a haptic spatial experience -
in a 2 dimensional representation. It became a lot more about how landscape and interior visual language could work together to create in a 2 dimensional representation. It became a lot more about how landscape and interior visual language could work together to create
this experience and what that meant in terms of existential intimacy. It was also a lot more about physically drawing on site and using hand drawings as a main exploration rather than digital -which somehow connected me more to the process and the design itself. My hand drawings as a main exploration rather than digital -which somehow connected me more to the process and the design itself. My
limited knowledge of landscape and engineering meant that I had to rely on advice a lot of the time to make decisions regarding the design within the limitations of engineering and landscape. It was frustrating and scary at times waiting for the advice and jumping design within the limitations of engineering and landscape. It was frustrating and scary at times waiting for the advice and jumping
into the unknown but on a practical level the storm water detention design would work. In reality if this were to be an actual built into the unknown but on a practical level the storm
project it would require a multidisciplinary team.

Within these confines I have managed in this project to develop some design concepts that would result in an essentially intimate experience should the be outcome.

Existential Intimacy as a concept has the potential for a lot more exploration and testing, as I believe I have only skimmed the surface of what it is able to achieve. In order to develop this concept further I would tackle a project a little bit less foreign but still challenging spatial boundaries. 
Interior architecture as a discipline have the potential to tackle much larger meaningful spaces than at present, and the crossover between interior and landscape has been a really interesting and useful one as it has cemented the importance of context and connection to site, something interior lacks.

This research thesis has developed my design process and the way that I look at space. By being able to appreciate the skill involved in landscape and apply that to my own designs means that I have begun to develop a richer design palate. It has also meant that there
have been a few drawings or processes which have taken me longer than perhaps somebody based in landscape, but pushing through have been a few drawings or process
these has helped my development.

This concept of existential intimacy is something which I don't believe I will ever stop applying to my designs or searching for in everyday experiences. To me, this concept pushes both landscape and interior, into a much more powerful design space. 
Existential intimacy is an intense spatial experience and design technique that has huge potential to change how we read and design spaces. It provides the unique ability to connect to something bigger than the direct space or context unfolding the boundaries of space to become limitless and encompass the whole world. It is this limitlessness of the boundaries that makes it an even more interesting concept when considered in the relationship to interior architecture and the usual precept that interior must be bound by a building. This research sits on the boundary of landscape and interior architecture touching into engineering through the manipulation of stormwater design. Although a challenging research thesis it has presented opportunities for the disciplines of interior and landscape architecture to cross over more and share techniques and language from one another. Each disciplines weakness is the others strength and by bringing these disciplines together through the concept of existential intimacy I created an expansiveness across scales. The project itself has potential to be further developed to become a fully functioning prototype. This is not limited to just stormwater virtually any engineered system has the potential to be manipulated through existential intimacy. The concept of existential intimacy warrants further exploration to test its full capacity and potential. 
6.0 List of Figures

Figure 1: Shalekhet - Fallen Leaves, by Menashe Kadishman (R.)

Figure 2: Shalekhet - Fallen Leaves, by Menashe Kadishman (fiore-rosso, "Steel Faces - Ian Bramham [Daniel Libeskind's Jewish Museum, Berlin]")

Figure 3: Shalekhet - Fallen Leaves, by Menashe Kadishman (fiore-rosso, "Daniel Libeskind")

Figure 4: Fourth year Interior Architectural exploration within the Landscape (Author)

Figure 5: Explorative diagram of the existential intimacy qualities in the Jetty (Author);

Figure 6: Jetty location maps (TerraMetrics)

Figure 7: Jetty location maps (TerraMetrics)

Figure 8: Jetty approach and entry (Author)

Figures 9: Views and direct surroundings on the Jetty (Author)

Figure 10: Views and direct surroundings on the Jetty (Author)

Figure 11: Views and direct surroundings on the Jetty (Author)

Figure 12: Explorative diagram of the existential intimacy qualities in the Jetty (Author) 
Figures 13: Design forays with the addition of water (Author)

Figure 14: Design forays with the addition of water (Author)

Figure 15: Design forays with the addition of water (Author)

Figure 16: Design forays with the addition of water (Author)

Figure 17: Why is existential intimacy valuable map (Author)

Figure 18: The Meeting Place - Laneways: By George! Hideen Networks (ASPECT Studios, Herbert \& Mason, and Derlot Studio) Figure 19: The Meeting Place - Laneways: By George! Hideen Networks (ASPECT Studios, Herbert \& Mason, and Derlot Studio) Figure 20: The Meeting Place - Laneways: By George! Hideen Networks (ASPECT Studios, Herbert \& Mason, and Derlot Studio) Figure 21: The Meeting Place - Laneways: By George! Hideen Networks (ASPECT Studios, Herbert \& Mason, and Derlot Studio) Figure 22: The Meeting Place - Laneways: By George! Hideen Networks (ASPECT Studios, Herbert \& Mason, and Derlot Studio) Figure 23: The Meeting Place - Laneways: By George! Hideen Networks (ASPECT Studios, Herbert \& Mason, and Derlot Studio) Figure 24: Exploration of the qualities and manifestations of water (Author)

Figure 25: Analysis of stormwater and intimacy - connection through water (Author)

Figure 26: Bridge, by Michael Cross (Cross)
Figure 27: Bridge, by Michael Cross (Cross)

Figure 28: Bridge, by Michael Cross (Cross)

Figure 29: Bridge, by Michael Cross (Cross)

Figure 30: Rain Room by rAndom International (rAndom International, Rain Room)

Figure 31: Rain Room by rAndom International (rAndom International, Rain Room)

Figure 32: Rain Room by rAndom International (rAndom International, Rain Room by rAndom International at the Barbican)

Figure 33: Rain Room by rAndom International (rAndom International, Rain Room)

Figure 34: Rain Room by rAndom International (rAndom International, Rain Room by rAndom International at the Barbican)

Figure 35: Rain Room by rAndom International (rAndom International, Rain Room by rAndom International at the Barbican)

Figure 36: Moses Bridge by RO\&AD Architects (RO\&AD architecten)

Figure 37: Moses Bridge by RO\&AD Architects (RO\&AD architecten)

Figure 38: Moses Bridge by RO\&AD Architects (RO\&AD architecten)

Figure 39: Moses Bridge by RO\&AD Architects (RO\&AD)

Figure 40: Moses Bridge by RO\&AD Architects (RO\&AD) 
Figure 41: Moses Bridge by RO\&AD Architects (RO\&AD)

Figure 42: Moses Bridge by RO\&AD Architects (RO\&AD)

Figure 43: Moses Bridge by RO\&AD Architects (RO\&AD)

Figure 44: Moses Bridge by RO\&AD Architects (RO\&AD)

Figure 45: Moses Bridge by RO\&AD Architects (RO\&AD)

Figure 46: Moses Bridge by RO\&AD Architects (RO\&AD)

Figure 47: Moses Bridge by RO\&AD Architects (RO\&AD)

Figure 48: The Water Temple, by Tadao Ando (Ando, Water Temple)

Figure 49: The Water Temple, by Tadao Ando (Ando, Water Temple - Shingonshu Honpukuji)

Figure 50: The Water Temple, by Tadao Ando (Ando, Water Temple)

Figures 51: Silence, by Tadao Ando + Blair Associates (Ando and Blair Associates)

Figure 52: Silence, by Tadao Ando + Blair Associates (Ando and Blair Associates)

Figure 53: Silence, by Tadao Ando + Blair Associates (Ando and Blair Associates)

Figures 54: Benesse House Museum, by Tadao Ando (Ando, Benesse House Oval)
Figure 55: Benesse House Museum, by Tadao Ando (Ando, Benesse House Museum) Figure 56: Benesse House Museum, by Tadao Ando (Ando, Benesse House Oval) Figure 57: Benesse House Museum, by Tadao Ando (Ando, Benesse House Museum) Figure 58: Existential intimacy assemblage (Author)

Figure 59: Synchronicity Island, by Jakub Szczęsny (Szczęsny) Figure 60: Synchronicity Island, by Jakub Szczęsny (Szczęsny) Figure 61: Synchronicity Island, by Jakub Szczęsny (Szzcęsny) Figure 62: Waitangi Park, by Wraight Athfield Landscape + Architecture (Author) Figure 63: Waitangi Park, by Wraight Athfield Landscape + Architecture (Author) Figure 64: Waitangi Park, by Wraight Athfield Landscape + Architecture (Author) Figure 65: Waitangi Park, by Wraight Athfield Landscape + Architecture (Author) Figure 66: Waitangi Park, by Wraight Athfield Landscape + Architecture (Author) Figure 67: Waitangi Park, by Wraight Athfield Landscape + Architecture (Author) Figure 68: Waitangi Park, by Wraight Athfield Landscape + Architecture (Author) 
Figure 69: Waitangi Park, by Wraight Athfield Landscape + Architecture (Author)

Figure 70: Waitangi Park, by Wraight Athfield Landscape + Architecture (Author)

Figures 71: The Circle, by Hoerr Schaudt Landscape Architects (Hoerr Schaudt Landscape Architects, The Circle in Uptown Normal)

Figure 72: The Circle, by Hoerr Schaudt Landscape Architects (Hoerr Schaudt Landscape Architects, The Circle)

Figure 73: The Circle, by Hoerr Schaudt Landscape Architects (Hoerr Schaudt Landscape Architects, The Circle in Uptown Normal)

Figure 74: New Zealand map locating Wellington (Author; Koordinates Ltd.; TerraMetrics and Google)

Figure 75: Wellington stormwater catchment map with outfalls (Wellington City Council 66)

Figure 76: Wellington map locating the Newtown Catchment (Author; Koordinates Ltd.; TerraMetrics and Google)

Figure 77: Ponding and flooding in the Newtown Catchment [1 in 50 year storm event] (Author; Koordinates Ltd.; TerraMetrics and

Google)

Figure 78: Contextual images of a flooding event in May 2013 (iWitness)

Figure 79: Contextual images of a flooding event in May 2013 (Wellington Reporters)

Figure 80: Contextual images of a flooding event in May 2013 (iWitness)

Figure 81: Contextual images of a flooding event in May 2013 (iWitness)
Figure 82: Contextual images of a flooding event in May 2013 (Wellington Reporters) Figure 83: Contextual images of a flooding event in May 2013 (Wellington Reporters)

Figure 84: Contextual images of a flooding event in May 2013 (Wellington Reporters)

Figure 85: Contextual images of a flooding event in May 2013 ("Flights Departing Wellington Airport Delayed by High Winds")

Figure 86: Contextual images of a flooding event in May 2013 (iWitness)

Figure 87: Contextual images of a flooding event in May 2013 (Wellington Reporters)

Figure 88: Contextual images of a flooding event in May 2013 ("Flights Departing Wellington Airport Delayed by High Winds") Figure 89: Contextual images of a flooding event in May 2013 ("Flights Departing Wellington Airport Delayed by High Winds") Figure 90: Contextual images of a flooding event in May 2013 (Wellington Reporters)

Figure 91: Available plots of land separated into different spatial exploration zones (Author; Koordinates Ltd.; TerraMetrics and Google)

Figure 92: Contextual images of the sense of each zone - Moses Bridge (RO\&AD)

Figure 93: Contextual images of the sense of each zone - The Water Temple (Ando)

Figure 94: Contextual images of the sense of each zone - Bridge (Cross) 
Figure 95: Contextual images of the sense of each zone - Check Dam (Design Impact)

Figure 96: Contextual images of the sense of each zone - Cloudscapes (Etherington, "Cloudscapes by Tetsuo Kondo Architects and Transsolar")

Figure 97: Contextual images of the sense of each zone - Sayamaike Historical Museum (arcspace)

Figure 98: Contextual images of the sense of each zone - Silence (Ando and Blair Associates)

Figure 99: Contextual images of the sense of each zone - Rain Room (rAndom International)

Figure 100: Contextual images of the sense of each zone - Stepped Tank at Hampi (Buchmann)

Figure 101: Contextual images of the sense of each zone - The Therme Vals (ArchDaily)

Figure 102: Contextual images of the sense of each zone - The Basilica Cistern (Destination 360)

Figure 103: Contextual images of the sense of each zone - The Therme Vals (Chang Hanway))

Figure 104: Wellington Town Belt (Wellington City Archives, “Town Belt [general File] Part 7”)

Figure 105: Views of Mount Victoria over the years (Wellington City Archives, Elevated View of Te Aro and Mount Victoria)

Figure 106: Views of Mount Victoria over the years (Wellington City Archives, Reclamation at Te Aro)

Figure 107: Views of Mount Victoria over the years (Wellington City Archives, Wellington from Kelburn Hills)
Figure 108: Views of Mount Victoria over the years (Wellington City Archives, Elevated View of Te Aro to Mount Victoria, from the Terrace)

Figure 109: Views of Mount Victoria over the years (Wellington City Archives, Wellington City, Looking towards Mount Victoria from Central Business District)

Figure 110: Views of Mount Victoria over the years - Mount Victoria from Kelburn (Author)

Figure 111: Views of Mount Victoria over the years - Mount Victoria from Newlands (Author)

Figure 112: Chosen design area of Mount Victoria located within the Newtown Catchment (Author; Koordinates Ltd.; TerraMetrics and Google)

Figure 113: Contextual images of the sense of the detention possibilites - Rain Room (rAndom International)

Figure 114: Contextual images of the sense of the detention possibilites - The Water Temple (Ando)

Figure 115: Contextual images of the sense of the detention possibilites - Moses Bridge (RO\&AD)

Figure 116: Contextual images of the sense of the detention possibilites - Bridge (Cross)

Figure 117: Contextual images of the sense of the detention possibilites - The Basilica Cistern (Destination 360)

Figure 118: Contextual images of the sense of the detention possibilites - Check Dam (Design Impact)

Figure 119: ArcMap flow path studies for Mount Victoria - overlaid with all areas water could be detained (Author; Koordinates Ltd.) 
Figure 120: ArcMap flow path studies for Mount Victoria with all areas water could be detained with context (Author; Koordinates Ltd.; TerraMetrics and Google)

Figure 121: Selecting important/valuable detention areas (Author; Koordinates Ltd.; TerraMetrics and Google)

Figure 122: Straight dam walls across important detention areas - using the assumption that for 1 meter depth of water $=0.25 \mathrm{~m} \mathrm{dam}$ wall thickness (Author; Koordinates Ltd.; TerraMetrics and Google)

Figure 123: Curved dam walls across important detention areas - using the assumption that using a curved wall halves the thickness from a straight wall for 2 meters depth of water $=0.25 \mathrm{~m}$ dam wall thickness (Author; Koordinates Ltd.; TerraMetrics and Google)

Figure 124: City approach to Cistern (Author)

Figure 125: City approach to Cistern (Author)

Figure 126: The Cistern cross section - before intervention (Author; Koordinates Ltd.)

Figure 127: The Cistern cross section [section 1 zoomed] - before intervention (Author; Koordinates Ltd.)

Figure 128: The Cistern cross section [section 2 zoomed] - before intervention (Author; Koordinates Ltd.)

Figure 129: The Cistern cross section [section 3 zoomed] - before intervention (Author; Koordinates Ltd.)

Figure 130: The Cistern cross section [section 4 zoomed] - before intervention (Author; Koordinates Ltd.)

Figure 131: The Cistern perspective view 1 - before intervention (Author)
Figure 132: The Cistern perspective view 1 - before intervention (Author)

Figure 133: The Cistern cross section - after addition of detention (Author; Koordinates Ltd.)

Figure 134: The Cistern cross section [section 1 zoomed] - after addition of detention (Author; Koordinates Ltd.)

Figure 135: The Cistern cross section [section 2 zoomed] - after addition of detention (Author; Koordinates Ltd.)

Figure 136: The Cistern cross section [section 3 zoomed] - after addition of detention (Author; Koordinates Ltd.

Figure 137: The Cistern cross section [section 4 zoomed] - after addition of detention (Author; Koordinates Ltd.

Figure 138: The Cistern perspective view 1 - after intervention (Author)

Figure 139: The Cistern perspective view 2 - before intervention (Author)

Figure 140: Approach and pathway around/through the Cascades (Author)

Figure 141: Approach and pathway around/through the Cascades (Author)

Figure 142: The Cascades cross section - before intervention (Author; Koordinates Ltd.)

Figure 143: The Cascades cross section [section 1 zoomed] - before intervention (Author; Koordinates Ltd.)

Figure 144: The Cascades cross section [section 2 zoomed] - before intervention (Author; Koordinates Ltd.)

Figure 145: The Cascades cross section [section 3 zoomed] - before intervention (Author; Koordinates Ltd.) 
Figure 146: The Cascades cross section [section 4 zoomed] - before intervention (Author; Koordinates Ltd.)

Figure 147: The Cascades cross section - after addition of detention (Author; Koordinates Ltd.)

Figure 148: The Cascades cross section [section 1 zoomed] - after addition of detention (Author; Koordinates Ltd.)

Figure 149: The Cascades cross section [section 2 zoomed] - after addition of detention (Author; Koordinates Ltd.)

Figure 150: The Cascades cross section [section 3 zoomed] - after addition of detention (Author; Koordinates Ltd.)

Figure 151: The Cascades cross section [section 4 zoomed] - after addition of detention (Author; Koordinates Ltd.)

\section{Figure a1: Antithesis (Jones and Ginzel, Antithesis)}

Figure a2: Atoll (Jones and Ginzel, Atoll)

Figure a3: Atoll (Jones and Ginzel, Atoll)

Figure a4: Ineffable (Jones and Branchi)

Figure a5: Ineffable (Jones and Branchi)

Figure a6: Ineffable (Jones and Branchi)

Figure a7: The Therme Vals, by Peter Zumthor (Etherington, "Photographs of Work of Peter Zumthor by Hélène Bineet")
Figure a8: The Therme Vals, by Peter Zumthor (Chang Hanway)

Figure a: The Therme Vals, by Peter Zumthor (Etherington, "Photographs of Work of Peter Zumthor by Hélène Binet")

Figure a10: The Therme Vals, by Peter Zumthor (Etherington, "Photographs of Work of Peter Zumthor by Hélène Binee")

Figure a11: The Therme Vals, by Peter Zumthor (Etherington, "Key Projects by Peter Zumthor")

Figure a12: The Therme Vals, by Peter Zumthor (ArchDaily))

Figure a13: The Therme Vals, by Peter Zumthor (ArchDaily))

Figure a14: The Therme Vals. by Peter Zumthor (ArchDaily)

Figure a15: The Therme Vals. by Peter Zumthor (Chang Hanway)

Figure a16: The Basilica Cistern Istanbul (Destination 360)

Figure a17: The Basilica Cistern Istanbul (Tourist in Turkey)

Figure a18: Cloudscapes, by Tetsuo Kondo Architects and Transsolar (Etherington, "Cloudscapes by Tetsuo Kondo Architects and

Transsolar")

Figure a19: Cloudscapes, by Tetsuo Kondo Architects and Transsolar (Etherington, "Cloudscapes by Tetsuo Kondo Architects and Transsolar")

Figure a20: Cloudscapes, by Tetsuo Kondo Architects and Transsolar (Etherington, "Cloudscapes by Tetsuo Kondo Architects and 


\section{Transsolar")}

Figure a21: Parc en Sauvy, by Georges Descombes (Patt)

Figure a22: Parc en Saury, by Georges Descombes (Patt)

Figure a23: Parc en Saury, by Georges Descombes (Patt)

Figure a24: Design Unknown, by Georges Descombes (Lopez)

Figure 225: Lake Lenexa (Roever)

Figure a26: Lake Lenexa (Unknown)

Figure a27: Lake Lenexa (Lenexa Kansas Parks and Recreation)

Figure a28: Lake Lenexa (Roever)

Figure a29: Lake Lenexa (Roever)

Figure a30: Stormwater examples in Seattle (Silvera Seamans)

Figure a31: Stormwater examples in Seattle (Silvera Seamans)

Figure a32: Stormwater examples in Seattle (Silvera Seamans)

Figure a33: Controlled Canal and Wet Swale (First Street Corridor Champaign, Illinois)
Figure a34: Design Development Spatial Perspective - before and after the addition of water (Author) Figure a35: Design Development Spatial Perspective - before and after the addition of water (Author) Figure a36: Design Development Spatial Perspective - before the addition of water (Author) Figure a37: Design Development Spatial Perspective - after the addition of water (Author) Figure a38: Design Development Spatial Perspective - Quarry before the addition of water (Author) Figure a39: Design Development Spatial Perspective - Quarry after the addition of water (Author) Figure a40: Design Development Spatial Perspective - Quarry before the addition of water (Author) Figure a41: Design Development Spatial Perspective - Quarry after the addition of water (Author) Figure a42: Design Development Spatial Perspective - before and after the addition of water (Author) Figure a43: Design Development Spatial Perspective - before and after the addition of water (Author) Figure a44: Conceptual sketches - design details (Author)

Figure a45: Conceptual sketches - design details (Author)

Figure a46: Quarry Design Development Cross Section - before and after the addition of water (Author) Figure a47: Cascades Design Development Cross Section - before and after the addition of water (Author) 


\subsection{Bibliography}

Allan, Penny, and Martin Bryant. "Resilience as a Framework for Urbanism and Recovery." Journal of Landscape Arcbitecture 6.2 (2011): 34-45. Print.

Amoroso, Nadia, ed. Representing Landscapes. A Visual Collection of Landscape Architectural Drawings. London and New York: Routledge, 2012. Print.

Ando, Tadao. Benesse House Museum. N. p., 1992. Web. 25 Feb. 2013.

--.. Benesse House Museum. N. p., 1992. Web. 25 Feb. 2013.

--.. Benesse House Oval. N. p., 1992. Web. 25 Feb. 2013.

--.. Water Temple. N. p., 1991. Web. 25 Feb. 2013.

--.. Water Temple - Shingonshu Honpukuji. N. p., 1991. Web. 25 Feb. 2013.

Ando, Tadao, and Blair Associates. Silence. N. p., 2011. Web. 25 Feb. 2013.

ArchDaily. “The Therme Vals / Peter Zumthor.” ArchDaily. N. p., 11 Feb. 2009. Web. 24 Feb. 2013.

Architecture of Change 2: Sustainability and Humanity in the Built Environment. Berlin: Die Gestalten Verlag, 2009. Print.

arcspace. "Sayamaike Historical Museum: Tadao Ando." arsspace.com. Design Blog/Magazine. N. p., 20 Oct. 2003. Web. 27 Feb. 
ASPECT Studios, Herbert \& Mason, and Derlot Studio. The Meeting Place - Laneways: By George! Hidden Networks. N. p., 2009. Web. 23 Feb. 2013

Avis, Rob. "Swales: Ther Permaculture Element That Really 'Holds Water." The Permaculture Research Institute. Organisation. N. p. 16 May 2012. Web. 30 June 2013

Bachelard, Gaston. The Poetics of Space. Trans. Maria Jolas. 2nd ed. Boston: Beacon Press, 1994. Print.

Bengtson, Harlan. "Excel Spreadsheet Templates for Storm Water Detention Pond Outlet Structure Design." Brighthub Engineering. N. p., 15 Nov. 2010. Web. 29 Sept. 2013.

Blackwell, Simon. Intense Wellington Flooding around Basin Reserve. Wellington: Brady Dyer Photographer, 2013. Video.

--.. "ZBTV: Flooding in Wellington." Newstalk ZB 6 May 2013 : 1. Print.

Booth, Carol, and Wendy Tubman. Water Down Under: Understanding and Managing Australias's Great Artesian Basin. Australia: Commonwealth of Australia, 2011. Print.

Buchmann, Wydawnictwo. "Pieszo przez Indie - Oliver Schulz." Nie Tylko Indie. N. p., 20 June 2013. Web. 26 July 2013.

Building the World: An Encyclopedia of the Great Engineering Projects in History. Westport, Conn: Greenwood Press, 2006. Print.

Cache, Bernard. Earth Moves: The Furnishing of Territories. Ed. Michael Speaks. Trans. Anne Boyman. Cambridge, Mass: MIT Press, 1995. Print. Writing Architecture.

Capacity Infrastructure. "Regional Standard for Water Services." Nov. 2012 : n. pag. Print.
Capacity Infrastructure Services Ltd. “Three Waters: Summary Asset Management Plan. Incorporating Water Supply, Wastewater and Stormwater 2011/12 - 2020/21." n. pag. Print.

Chang Hanway, Christine. "Poetry in Space: Vals Thermal Spa in Switzerland." Remodelista. Design Blog/Magazine. N. p., 19 June 2012. Web. 24 Feb. 2013.

Chanson, H., S. Jarny, and P. Coussot. "Dam Break Wave of Thixotropic Fluid." Journal of Hydraulic Engineering 132.3 (2006): 280-293. CrossRef. Web. 29 Sept. 2013.

Chanson, Hubert. "Sabo Check Dams: Mountain Protection Systems in Japan." Professor Hubert Chansson. N. p., 31 Mar. 2013. Web. 27 Sept. 2013.

"Check Dam." Wikipedia, the free encyclopedia 30 Aug. 2013. Wikipedia. Web. 29 Sept. 2013.

Columbia County GA. "Detention Structural Stormwater Controls." Columbia County Stormwater Management Design Manual. Vol. 2. Columbia County Georgia: N. p., 2009. 3.4-1 - 3.4-14. 2 vols.

Conewago Creek Initiative. "Check Dam.” Conewago Creek Initiative. N. p., 2012. Web. 27 Sept. 2013,

Conio, Andrew. "From Flesh to House." Architectural Theory Review 14.2 (2009): 131-141. Print.

Cross, Michael. Bridge. N. p., 2006. Web. 23 Feb. 2013.

Design Impact. “Check Dam.” Design Impact. Organisation. N. p., 2013. Web. 26 June 2013.

Destination 360. "Basilica Cistern." Destination 360. Travel. N. p., 2013. Web. 24 Feb. 2013. 
Etherington, Rose. “Cloudscapes by Tetsuo Kondo Architects and Transsolar.” Dezzen. Design Blog/Magazine. N. p., 6 Sept. 2010. Web. 28 Sept. 2012

---. "Key Projects by Peter Zumthor." Dezzen. Design. N. p., 18 Apr. 2009. Web. 24 Feb. 2013.

--.. "Photographs of Work of Peter Zumthor by Hélène Binet." Dezzen. Design. N. p., 27 Aug. 2009. Web. 24 Feb. 2013.

Evans, Robin. "Figures, Doors and Passages." Translations from Drawing to Building and Other Essays. 1st ed. London: Janet Evans and Architectural Association Publications, 1997. 55-91. Print.

--.- "The Rights of Retreat and the Rites of Exclusion: Notes Towards the Definition of the Wall." Translations from Drawing to Building and Other Essays. 1st ed. London: Janet Evans and Architectural Association Publications, 1997. 35-53. Print.

"Excel Formulas for Calculating the Volume of Storm Water Detention Ponds." Brighthub Engineering. N. p., n.d. Web. 29 Sept. 2013. fiore-rosso. "Daniel Libeskind." Here and There. A Visual Diary. Blog. N. p., Oct. 2011. Web. 24 Sept. 2012.

-... "Steel Faces - Ian Bramham [Daniel Libeskind's Jewish Museum, Berlin]." Here and There. A Visual Diary. Blog. N. p., Mar. 2012. Web. 24 Sept. 2012.

First Street Corridor Champaign, Illinois. "Controlled Canal and Wet Swale." First Street Corridor Champaign, Illinois. N. p.. 2013 Web. 23 Mar. 2013

"Flights Departing Wellington Airport Delayed by High Winds." One News / Newstalk ZB 6 May 2013 : 1. Print.

Ghosn, Rania, El Hadi Jazairy, and Stephen Ramos. “The Space of Controversies: An Interview with Bruno Latour”. Ed. Neyran Turan.
New Geographies O: Design, Agency, Territory 0 (2009): 122 - 135. Print.

Gibson, James J. “The Theory of Affordances." The Ecological Approach to Visual Perception. 1st ed. Boston: Houghton Mifflin Company, 1979. 127 - 143. Print.

Haliburton, Andrew. “Stormwater Management Facility”” Andrew Haliburton. Porffolio. N. p., n.d. Web. 22 Feb. 2013.

Harvey, Sarah, and Michael Daly. “Flooding Causes Road Havoc as Wild Weather Hits.” Stuff.co.nz 6 May 2013 : 1. Print.

Hillier, Bill, and Julienne Hanson. "Buildings and Their Genotypes." Social Logic of Space. Cambridge: Cambridge University Press, 1984. 143-175. Print.

Hoerr Schaudt Landscape Architects. The Circle. N. p., 2011. Web. 23 Feb. 2013.

--.. The Circle in Uptown Normal. N. p., 2011. Web. 28 Feb. 2013.

Holl, Steven, Juhani Pallasmaa, and Alberto Pérez Gómez. Questions of Perception: Phenomenology of Architecture. 2nd ed. San Francisco, CA: William Stout, 2006. Print.

Hoyer, Jacqueline et al. Water Sensitive Urban Design: Principles and Inspiration for Sustainable Stormwater Management in the City of the Future: Elaborated in the Context of the Research Project SWITCH - Managino Water for the City of the Futurel. Berlin: Jovis Verlas GmbH, 2011. Print.

Hume, Patty. “Lawrence Halprin: Auditorium Forecourt Fountain (Ira Keller), Portland.” Grow 5 Feb. 2010. Web. 27 Sept. 2013. Hutt City Council. Petonés Artesian Water. Hutt City Council, 2003. Print. 
HylgeriaK. English: Check Dams near Barcelonnette, France. N. p., 2009. Wikimedia Commons. Web. 29 Sept. 2013. International Commission on Large Dams. "Technology of Dams." Commission Internationale Des Grands Barrages: International Commission on Large Dams. Engineering. N. p., 2013. Web. 24 Sept. 2013.

International Sabo Association. "Venezuera. Current Status of Sediment-Related Disasters and Countermeasures for Them in Venezuela." International Sabo Network. N. p., 2004. Web. 29 Sept. 2013.

"Introduction to Dams." Association of State Dam Safety Officials. N. p., 2013. Web. 27 Sept. 2013.

iWitness. "Wild Weather Lashes NZ." 3 News 6 May 2013. Web. 6 May 2013.

James, Patrick, and Hubert Chanson. "Historical Development of Arch Dams: From Roman Arch Dams to Modern Concrete Designs" Australian Civil Engineering Transactions CE43 (2002): 39-56. Print.

Jones, Kristin, and Walter Branchi. Ineffable. N. p., 2011. Web. 24 Apr. 2013.

Jones, Kristin, and Andrew Ginzel. Antithesis. N. p., 1989. Web. 24 Apr. 2013.

--.. Atoll. N. p., 1990. Web. 24 Apr. 2013.

Kadishman, Menashe. Shalekhet - Fallen Leaves. N. p., 1997.

Koordinates Ltd. “Koordinates.” Wellington. Auckland; Wellington: Koordinates Ltd. 2013, Web. 30 Apr. 2013.

Krishna. "Krishna’s ePages: Thiruvattar Aruvikkarai." Krishnás ePages 1 Apr. 2012. Web. 27 Sept. 2013.
Lake Superior Suluth Streams. "Grassed Swales." Lake Superior Suluth Streams.org. N. p., 2013. Web. 23 Mar. 2013. Leatherbarrow, David. "Leveling the Land." Recovering Landscape: Essays in Contemporary Landscape Architecture. New York: Princeton Architectural Press, 1999.171 - 184. Print.

Lenexa Kansas Parks and Recreation. “Lake Lenexa at Black Hoof Park.” Lenexa. Council. N. p., n.d. Web. 26 Apr. 2013. Lenexa Kansas Rain to Recreation. "Brentwood: Watershed Management to Prevent Flooding." n. pag. Print.

--.. "Flat Rock Creek: Stabilizing Banks and Reducing Flooding." n. pag. Print.

--.. "Hidden Woods Pond:Restoring Water Quality and Natural Habitat." n. pag. Print.

--.. "Lake Lenexa: Emplifying the Sustainability Triple Bottom Line." n. pag. Print.

--.. "Manchester Park: A Naturally Designed Streamway." n. pag. Print.

---. "Mize Lake: Bioretention Cells Improve Water Quality." n. pag. Print.

-.-. "Parkhurst Streamway: Cleaning City Center Waters for Shawnee Mission Lake." n. pag. Print.

Libeskind, Daniel. "Daniel Libeskind, 'Proof of Things Invisible' (1997)." The Architecture Reader: Essential Writings from Vitruvius to the Present. Ed. A. Krista Sykes. 1st ed. New York: George Brazille Publishers, 2007. 264-268. Print.

Lopez, Carlos. "An Architect in the Landscape." Bafci: Buenos Aires Festival International De Cine Independiente. N. p., 2010. Web. 25 July 2013. 
Manaugh, Geoff. “Musicalizing the Weather through Landscape Architecture." BLDG BLOG. Blog. N. p., 1 Sept. 2005. Web. 28 Sept. 2013.

Max Cohen. "University of Massachusetts at Amherst Rain Garden: 2010." Max Cohen Design. Design Portfolio. N. p., 2010. Web. 28 Sept. 2013.

Ministry for the Environment. "Preparing for Climate Change: A Guide for Local Government in New Zealand. Part One - Current and Future Climate." Ministry for the Environment. Government. N. p., 2013. Web. 28 Aug. 2013.

Moaveni, Saeed. Engineering Fundamental: An Introduction to Engineering. 3rd ed. Toronto, Ontario, Canada: Thomson, 2008. Print. Moved to Design. Melbourne, Vic: RMIT University Press, 2007. Print.

"Multi Arch Check Dams Taken Up Under - RSVY." Bidar. N. p., n.d. Web. 29 Sept. 2013.

NIWA Taihoro Nukurangi. “High Intensity Rainfall System V3." NIWA. Environmental. N. p., 2013. Web. 28 Aug. 2013.

---. "HIRDS Help." NIWA. Environmental. N. p., 2013. Web. 28 Aug. 2013.

OLIN. "OLIN Presents Sustainable Stormwater Management at 2009 AIA Conference." The Olin Studio. Blog. N. p., 6 Apr. 2009. Web. 23 Feb. 2013.

Oxford University Press. "Assemblage." Oxford Dictionaries 2013.
--.. "Intimacy." Oxford Dictionaries 2013.

Pallasmaa, Juhani. The Embodied Image: Imagination and Imagery in Architecture. Chichester: John Wiley \& Sons Inc, 2011. Print. AD

--.. The Eyes of the Skin: Architecture and the Senses. 3rd ed. Chichester, West Sussex: Wiley, 2012. victoria.lconz.ac.nz Library Catalog. Web. 3 Apr. 2013.

Parks and Reserves. "Wellington Town Belt Draft Management Plan, Part Two Specific Policies Management Area 11 Mount Victoria, Mar. 1994 : n. pag. Print.

Parkyn, Neil. SuperStructures: The World's Greatest Modern Structures. London: Merrell, 2004. Print.

Patt, Trevor. "Parc En Sauvy.” fickr. Photo sharing. N. p., 16 June 2012. Web. 25 July 2013. Positively Wellington Tourism. “Weather." WellingtonNZ.com. N. p., 2013. Web. 20 Oct. 2013.

R., Gerhard. "Void - Jüdisches Museum Berlin." fickr. Photo sharing. N. p., 24 June 2011. Web. 24 Sept. 2012.

Ramsey-Washington Metro Watershed District. "Vegetated Swale." Ramsey-Washington Metro Watershed District. N. p., 2013. Web. 23 Mar. 2013.

rAndom International. Rain Room. N. p., 2012. Web. 23 Feb. 2013.

--.. Rain Room by rAndom International at the Barbican. N. p., 2012. Web. 23 Feb. 2013. 
Rasor, Mitchell. “Well-Timed: Site Works of Georges Descombes." Architalx Journal 3 (2000): 16. Print.

"Reader Videos: Wellington Floods." The New Zealand Herald 6 May 2013 : 1. Print.

Representing Landscapes: A Visual Collection of Landscape Architectural Drawings. Abingdon, Oxon ; New York: Routledge, 2012. Print. Rice, Charles. "Bourgeois Inhabitations: Theory and the Historical Emergence of the Interior." Architectural Theory Review 8.2 (2003): 143-151. Print.

Rinne, Katherine Wentworth. The Waters of Rome: Aqueducts, Fountains, and the Birth of the Baroque City. 1st ed. New Haven: Yale University Press, 2010. Print.

RO\&AD. Sunken Bridge by ROÆAD. N. p., 2010

RO\&AD architecten. Moses Bridge by ROU'AD Architects. N. p., 2010.

Roever, John. “Johnson County, KS." fickr. Photo sharing. N. p., 1 Mar. 2009. Web. 28 May 2013.

Salazar, LeRoy et al. Irrigation Reference Manual. Peace Corps' Information Collection \& Exchange, 1994. Web. 29 Sept. 2013.

Scranton Gillette Communications. “Concrete Detention Structure.” Storm Water Solutions. N. p., 2013. Web. 29 Sept. 2013.

Serres, Michel. The Five Sensses: A Philosophy of Mingled Bodies. Trans. Margaret Sankey and Peter Cowley. 2nd ed. London and New York: Continuum International Publishing Group, 2008. Print.
Silvera Seamans, Georgia. “Amenity Potential of Stormwater Management." Local Ecologist. Blog. N. p., 9 Nov. 2009. Web. 12 Mar. 2013.

SKM. “Taranaki Street Stormwater Model and Flood Hazard Maps.” 3 July 2006 : n. pag. Print.

SMRC. “Stormwater Design Example: Pond.” The Stormwater Manager's Resource Center. Engineering. N. p., n.d. Web. 26 June 2013 Solanki, Pratik. “Types of Dams: Introduction and Classification.” Pratik Solankis Blog. Blog. N. p., 20 Sept. 2012. Web. 10 July 2013 Stormwater. “Sustainable Stormwater Management." Sustainable Stormwater Management. Blog. N. p., 2013. Web. 13 Mar. 2013. --.. "Trees in Captivity." Sustainable Stormwater Management. N. p., 30 Aug. 2007. Web. 13 Mar. 2013. "Stormwater Detention System - Retention Pond to Reduce Peak Stormwater Runoff Rate to Pre-Development Levels." Brighthub Engineering. N. p., n.d. Web. 29 Sept. 2013.

Strom, Steven, Kurt Nathan, and Jake Woland. Site Engineering for Landscape Architects. 6th ed. Hoboken, N.J: John Wiley \& Sons, Inc, 2013. victoria.lconz.ac nz Library Catalog. Web. 20 Mar. 2013

Sullivan, Grant. Flooding at Basin Reserve affer Massive Downpour in Wellington. Wellington: Brady Dyer Photography, 2013. Video. Sustainable City Network. "Green Streets Go Mainstream in Portland." Sustainable City Network. N. p., 2013. Web. 26 Feb. 2013. Szczęsny, Jakub. Synchronicity Island. N. p., 2009. Web. 23 Feb. 2013.

Tadao Ando Architect \& Associates. “Tadao Ando." Tadao Ando. N. p., 2009. Web. 25 Feb. 2013 
TerraMetrics. "Wellington." Aerial Photographs. Wellington: Google Maps 2013, Web. 23 Feb. 2013.

TerraMerrics, and Google. "Wellington." Map. Google 2013, Web. 25 Sept. 2013.

Tourist in Turkey. “Imperial Tour: Basilica Cistern.” Tourist in Turkey. N. p., 2013. Web. 24 Feb. 2013.

Town Planning Department, Wellington City Council. “You, Mount Victoria and The Future.” Aug. 1976 : n. pag. Print

“UMass Rain Garden.” MAX COHEN DESIGN. N. p., n.d. Web. 29 Sept. 2013.

United States Department of the Interior Bureau of Reclamation. "Design Criteria for Concrete Arch and Gravity Dams." 1977. Web. 24 Sept. 2013.

Unknown. "Lake Lenexa Dam \& Spillway." fffound!' blog. N. p., 30 Jan. 2010. Web. 26 May 2013.

Videoblocks. "Videoblocks: Unlimited Downloads of Stock Media." Videoblocks. Audio recordings. N. p., 2014. Web. 15 Jan. 2014.

Vidler, Anthony. The Architectural Uncanny: Essays in the Modern Unhomely. Cambridge, Mass: MIT Press, 1992. Print.

Walker, B.H., and D. Salt. Resilience Thinking: Sustaining Ecosystems and People in a Changing World. Washington D.C., USA: Island Press, 2006. Print.

Wellington City Archives. Aerial Transparency, Sheet N32 [1970]. N. p., 1970. Print.

--.. Aerial Transparency, Sheet N32 [1977]. N. p., 1977. Print.

--.. Aerial Transparency, Sheet O32 [1970]. N. p., 1970. Print.
--.. Aerial View of Mount Victoria. N. p., 1947. Print.

--.. Arthur Street, Looking Eass towards Mount Victoria. N. p., 1940s. Print.

--.. Elevated View of Te Aro and Mount Victoria. N. p., 1863. Print.

--.. Elevated View of Te Aro to Mount Victoria, from the Terrace. N. p., 1910. Print.

---. "G H Baylis, Regarding Quarry at Mount Victoria Reserve." 16 July 1880 : n. pag. Print.

--.- Mount Victoria Development Scheme [004046A]. N. p., 1964. Print.

--.. Mount Victoria Development Scheme [004046B]. N. p., 1964. Print.

---.. Mount Victoria Development Scheme [004047A]. N. p., 1964. Print.

---. Mount Victoria Development Scheme [004047B]. N. p., 1964. Print.

-.-.. Mount Victoria Development Scheme [004050B]. N. p., 1964. Print.

---.. Mount Victoria Development Scheme [004051B]. N. p., 1964. Print.

--.. Mount Victoria Development Scheme [004052A]. N. p., 1964. Print.

--.. Mount Victoria Development Scheme [004052B]. N. p., 1964. Print.

--.. Mount Victoria Development Scheme [004054B]. N. p., 1964. Print. 
--.. Mount Victoria Development Scheme [004055B]. N. p., 1964. Print.

--.. Mount Victoria from Te Aro. N. p., 1930. Print.

--.. Overlooking Te Aro, Looking North towards the Harbour and Mount Victoria. N. p., 1870. Print.

--.. Part Four of a Panorama of Te Aro from the Ford Building, Courtenay Place. N. p., 1923. Print.

--.. "Quarry: Ellice Street, Mount Victoria." 19621928 : n. pag. Print.

--.. "Quarry: Ellice Street, Mount Victoria." 19701963 : n. pag. Print.

--.. Reclamation at Te Aro. N. p., 1884. Print.

--.. "Spring from Town Belt, South End Grant Road." 1935 : n. pag. Print.

--.. "Stormwater - Stafford Street, Town Belt." 20031934 : n. pag. Print.

-.-. "Stormwater - Watercourse - Town Belt through Wakefield Park." 19581927 : n. pag. Prin.

--.- "Stream: Between Liardet Street and through Town Belt to Stanley Street, Palm Grove, Royal Street to Adelaide Road - Culverting of Stream, Wakefield Park." 19711930 : n. pag. Print.

--.. Streetscape, Ellice Street, Basin Reserve, Mount Victoria. N. p., 1955. Print.

--.. Te Aro, Wellington. N. p., 1868. Print.
---.. "Town Belt [General File] Part 1." 19351903 : n. pag. Print.

--.. "Town Belt [general File] Part 2." 19701935 : n. pag. Print.

--.. "Town Belt [general File] Part 3." 19741970 : n. pag. Print.

--.. "Town Belt [general File] Part 4." 19831974 : n. pag. Print.

--.. "Town Belt [general File] Part 5." 19871983 : n. pag. Print.

--.. "Town Belt [general File] Part 6." 19901987 : n. pag. Print.

---. "Town Belt [general File] Part 7." 19921990 : n. pag. Print.

--.. "Town Belt [general File] Part 8." 19941992 : n. pag. Print.

--.. Wellington City, Looking towards Mount Victoria from Central Business District. N. p., 1930. Print.

--.. Wellington from Catbolic Cemetery. N. p., 1885. Print.

-. Wellington from Kelburn Hills. N. p., 1890. Print.

Wellington City Council. “Assessment of Water \& Sanitary Services (2005)." 2005 : n. pag. Print.

--.. "History of Water Network." Wellington City Council. N. p., n.d. Web. 2 Aug. 2012

--.. "WCC Code of Practice for Land Development." Dec. 2012 : n. pag. Print. 
--, ed. "Wellington Towards 2040: Smart Capital. Central City Framework. Approach to Implementation.” Dec. 2011 : n. pag. Print.

Wellington Reporters. "Rain, Wind Hit Wellington Region." The Dominion Post 6 May 2013: 1. Print

Wraight Athfield Landscape + Architecture. Waitangi Park. N. p., 2006. Web. 20 Feb. 2013.

Youssef, Tahani Fahim. "Dams \& Reservoirs." Heading-Up Structures. N. p., n.d. Web. 27 Sept. 2013 


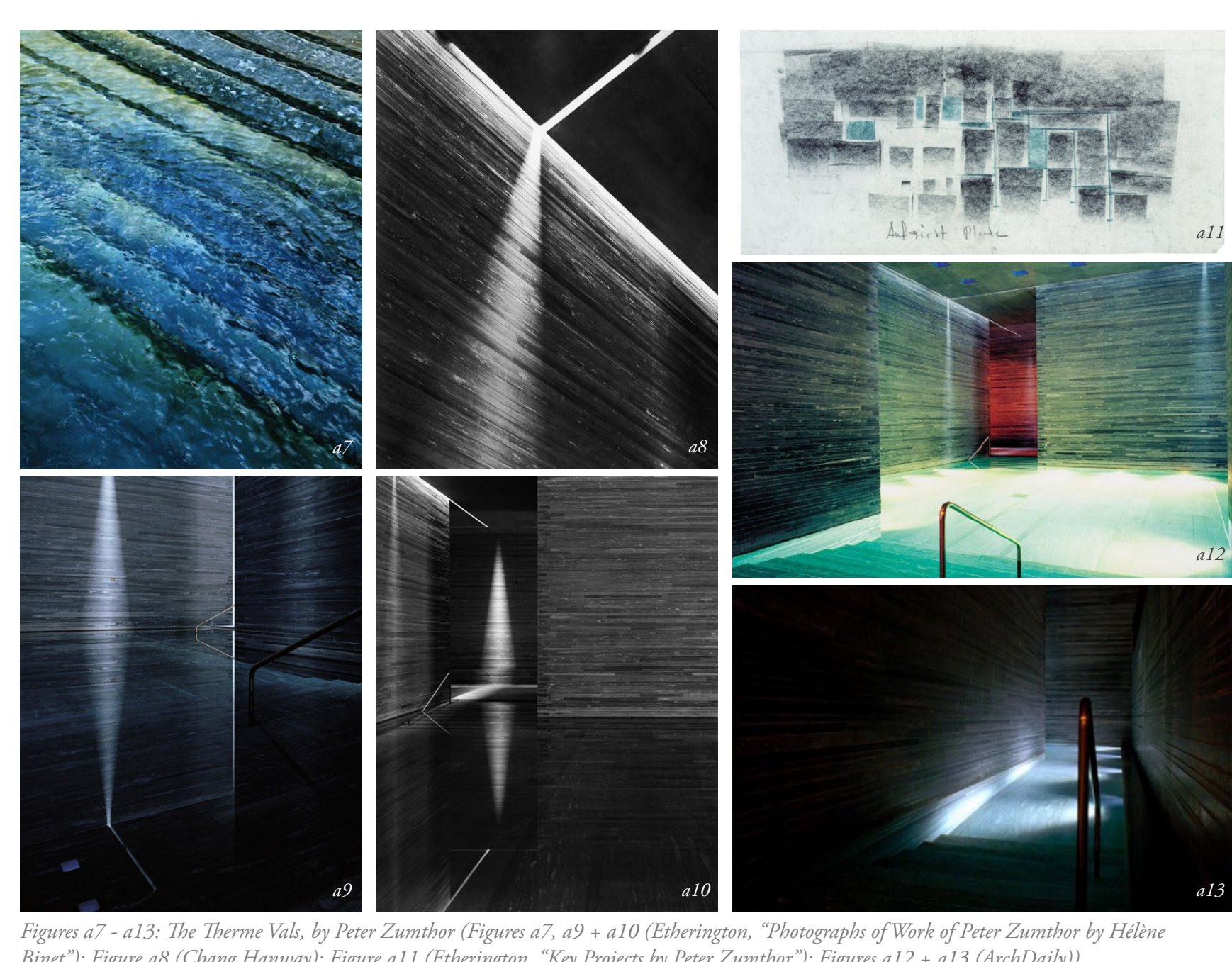

Peter Zumthor - The Therme Vals

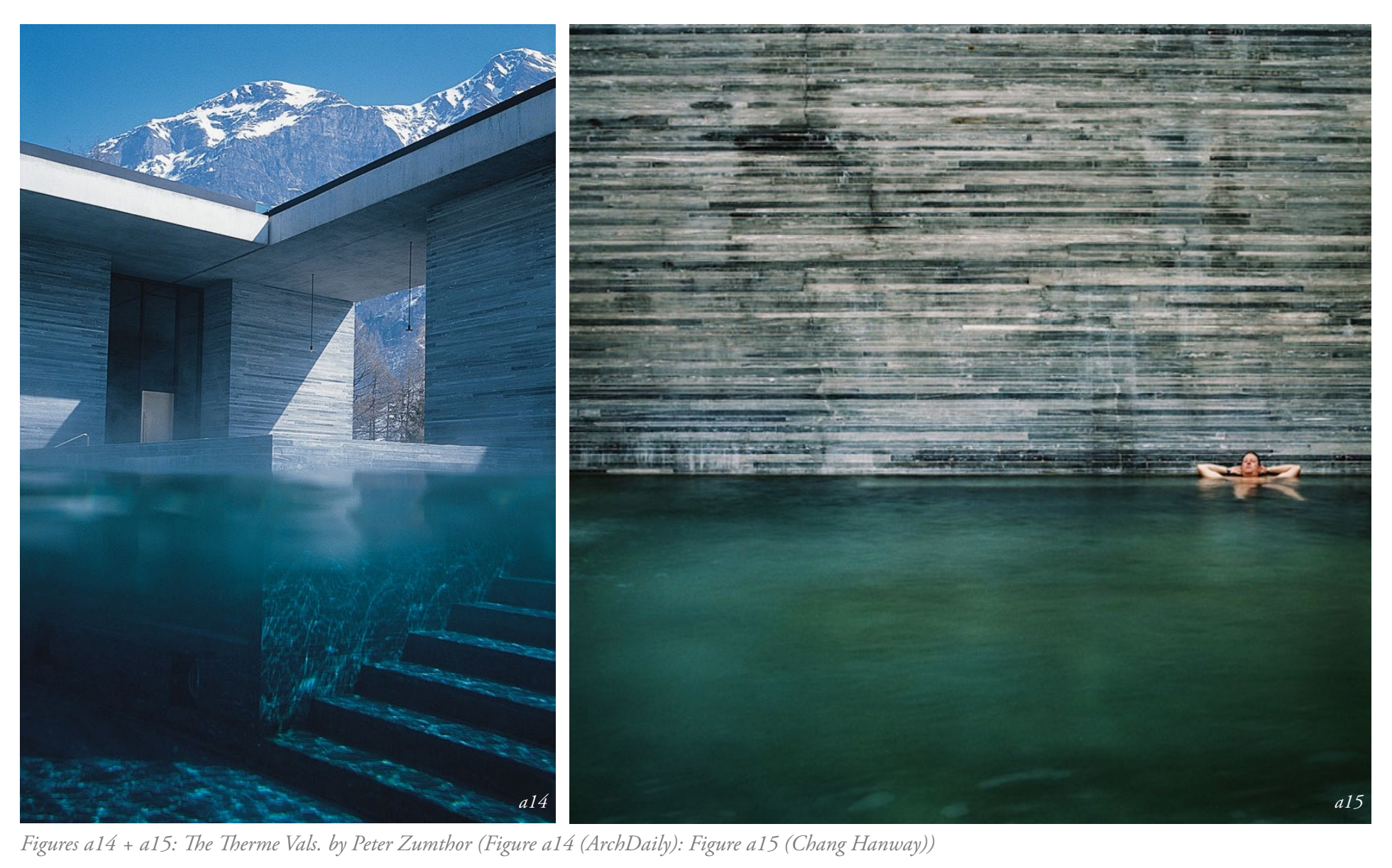




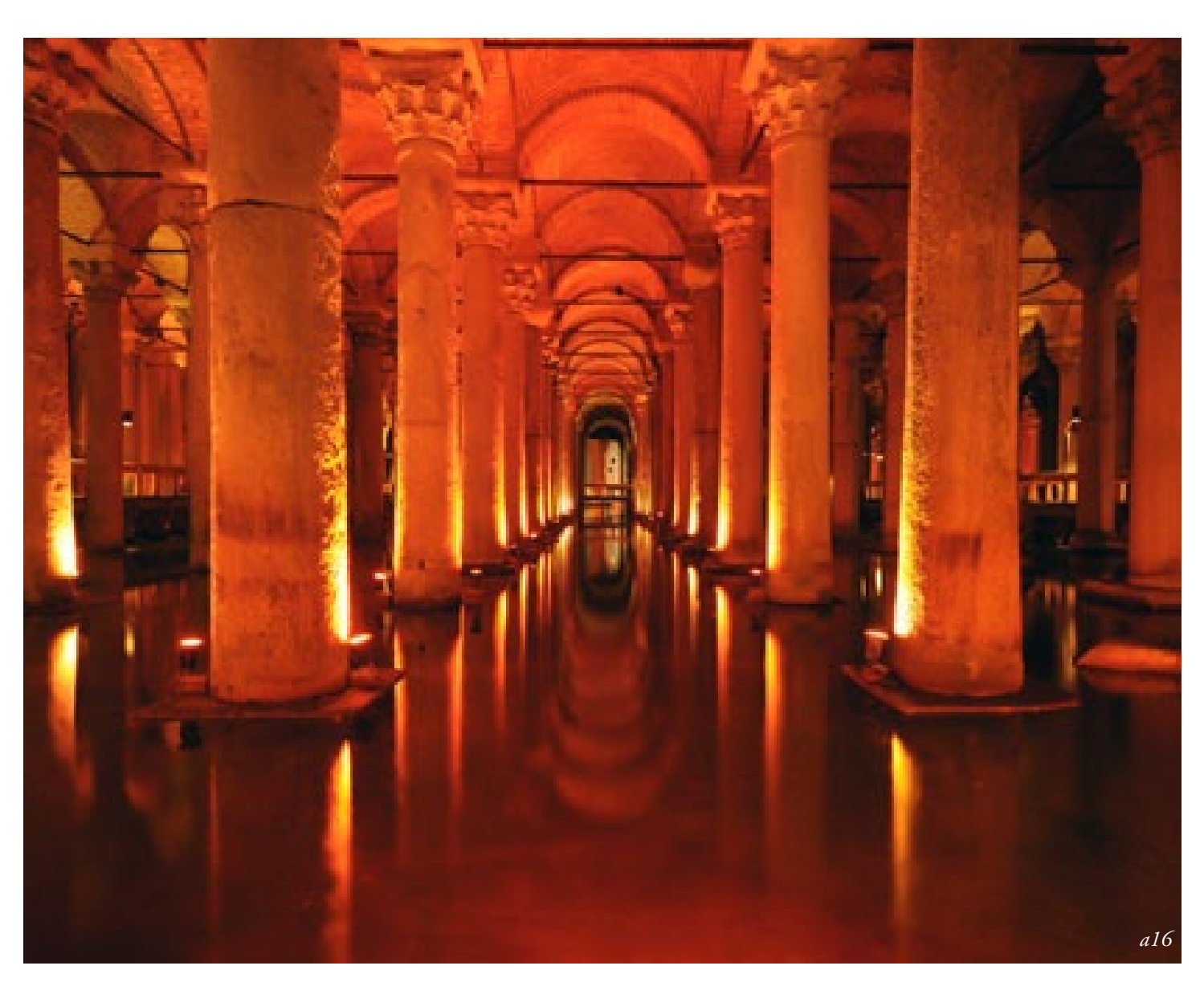

Basilica Cistern Istanbul

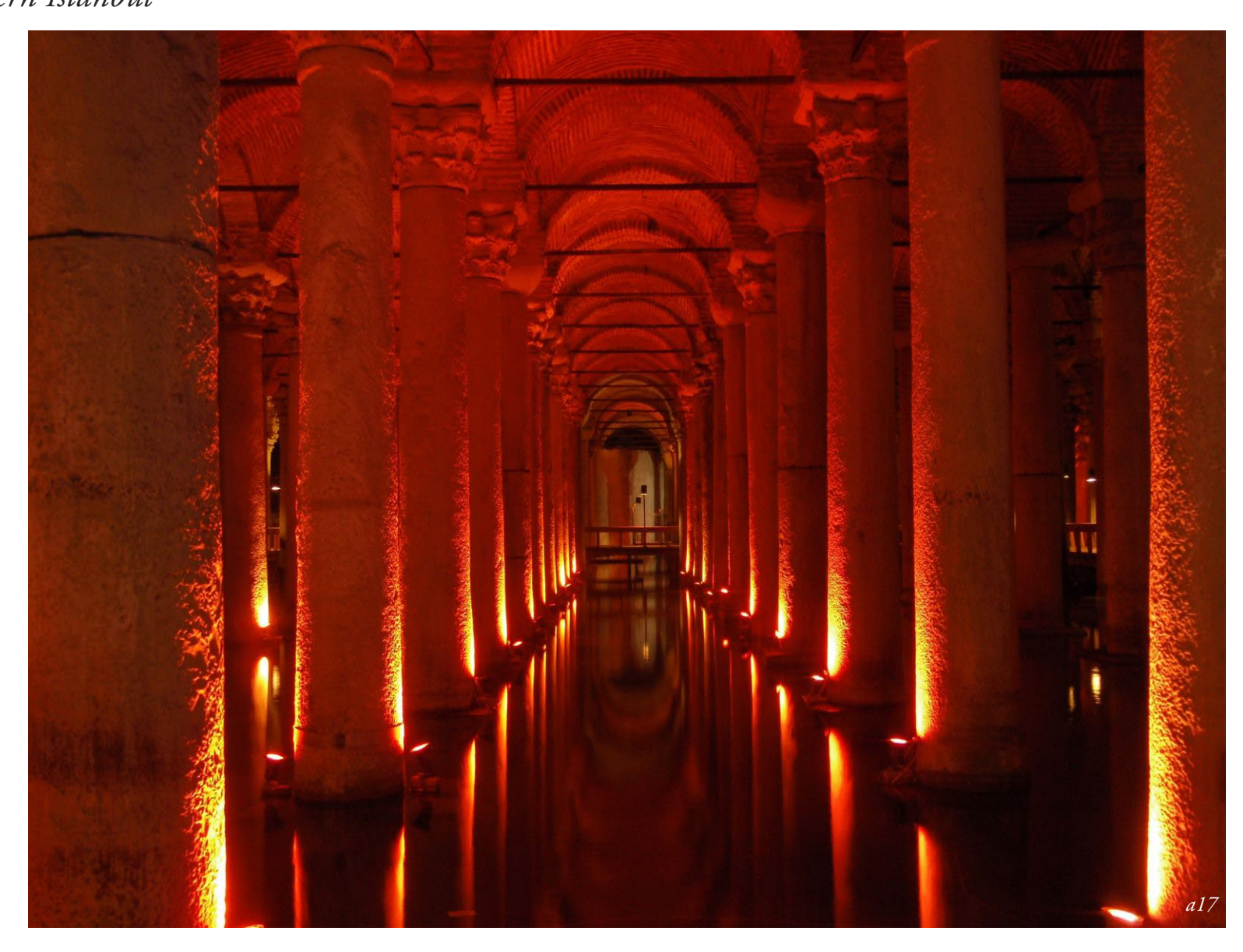



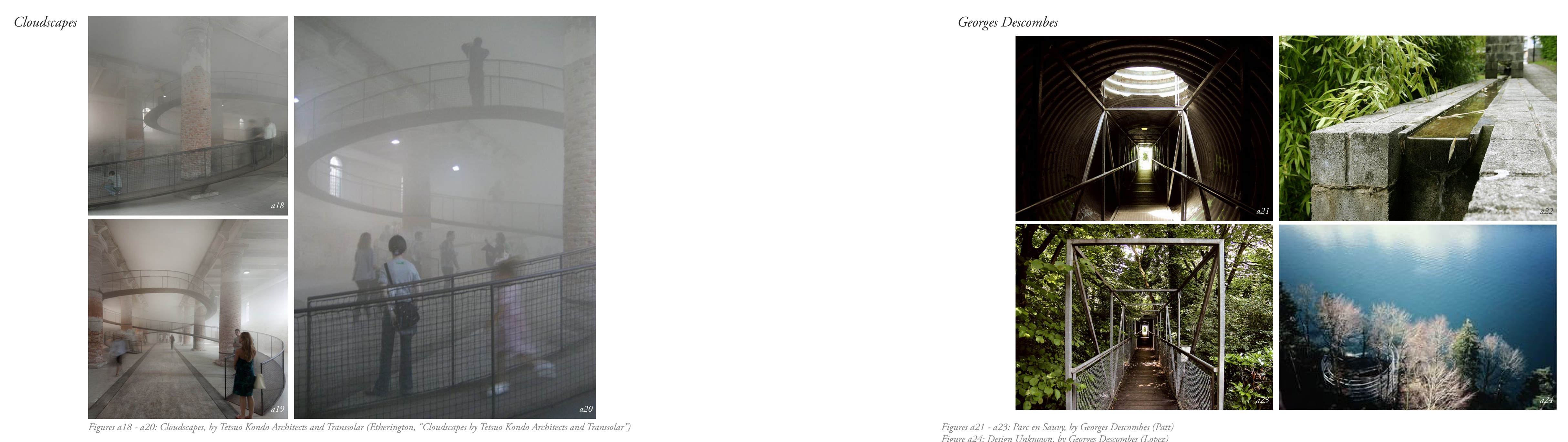
Lake Lenexa

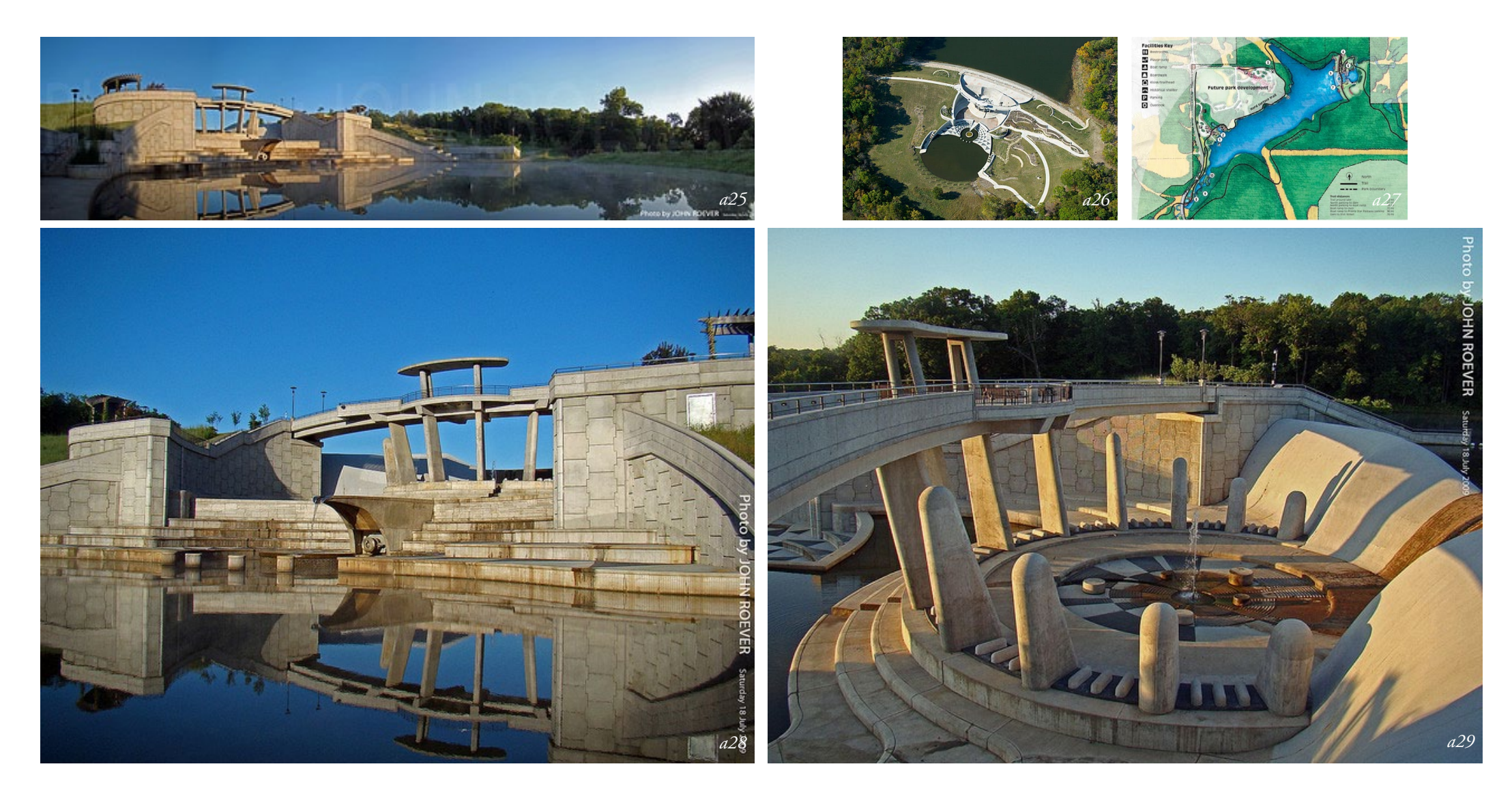

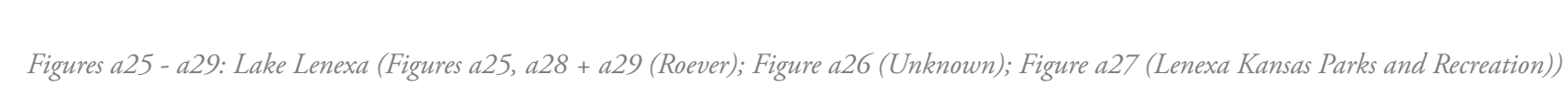

Stormwater Design

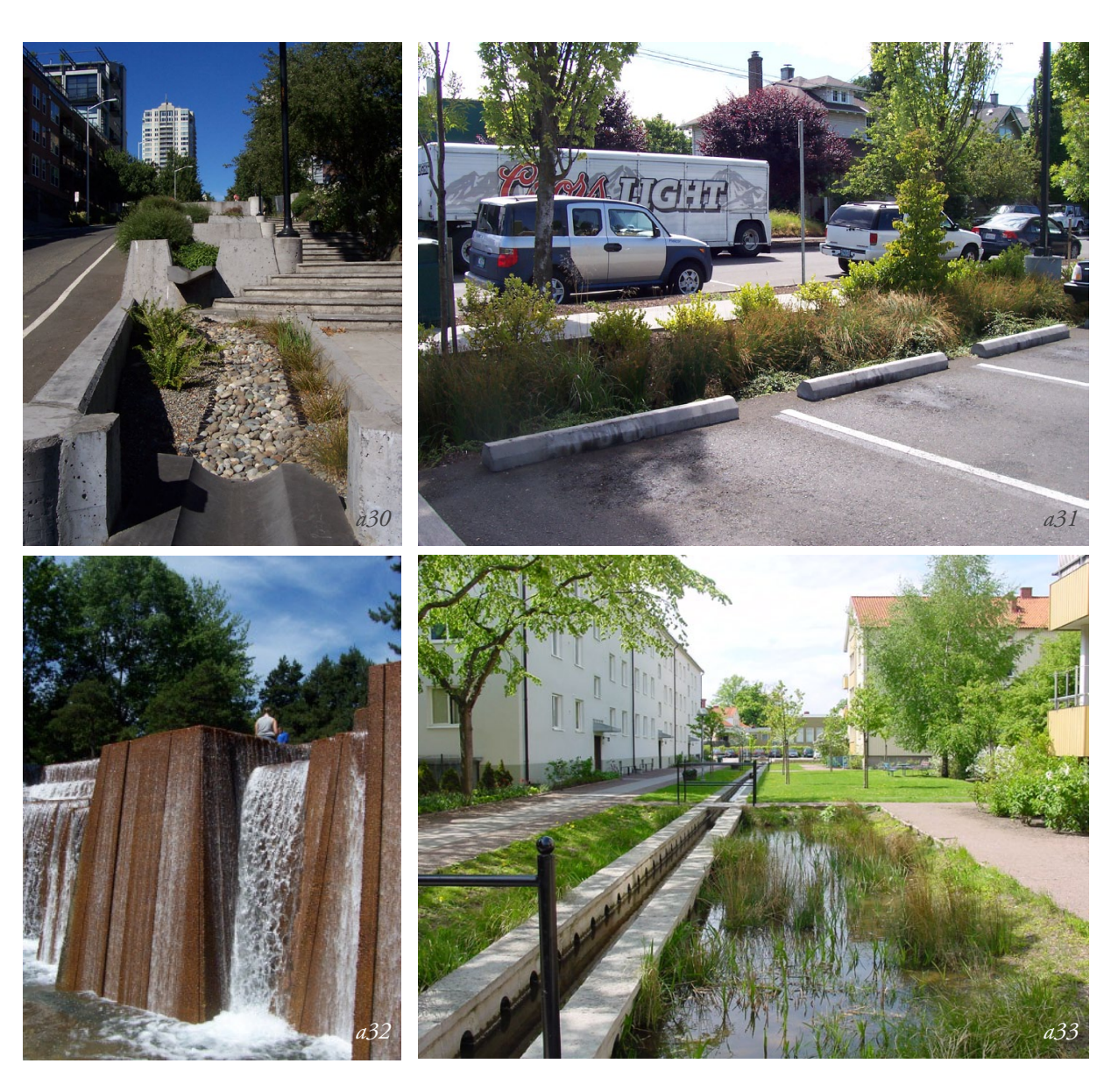

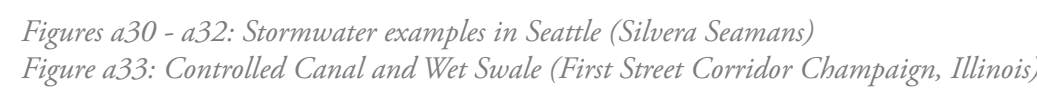




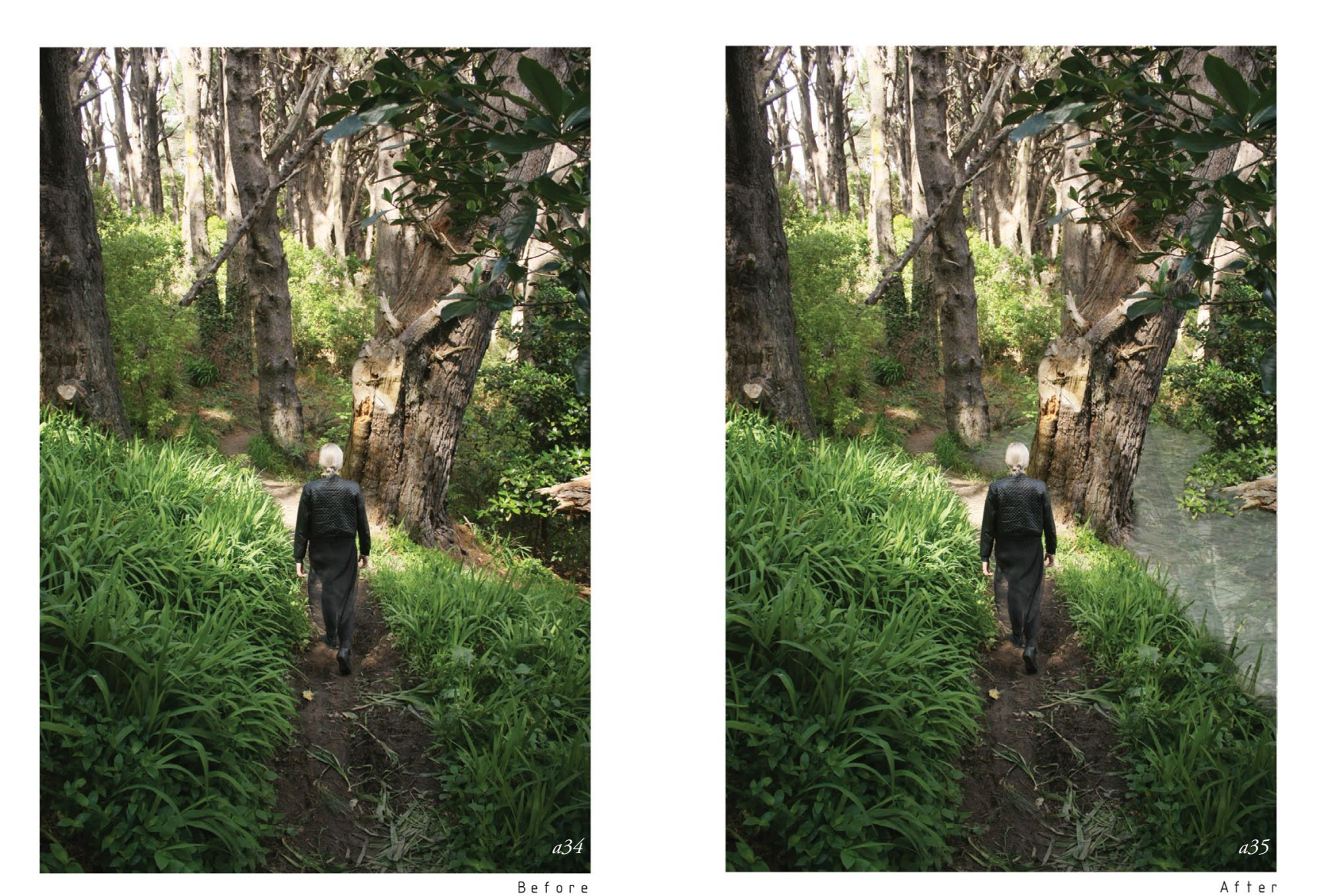



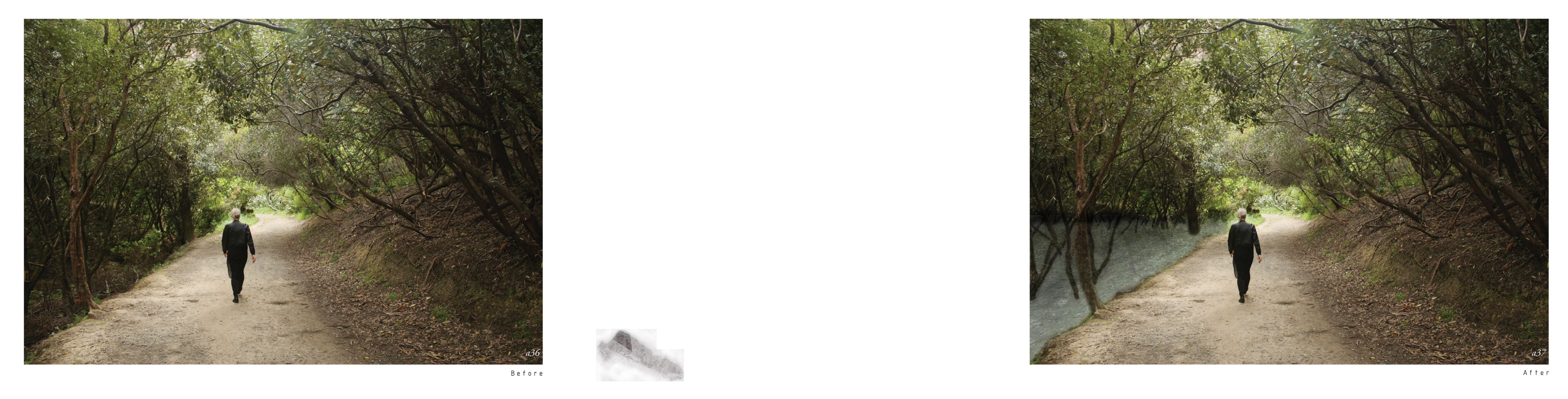

As 

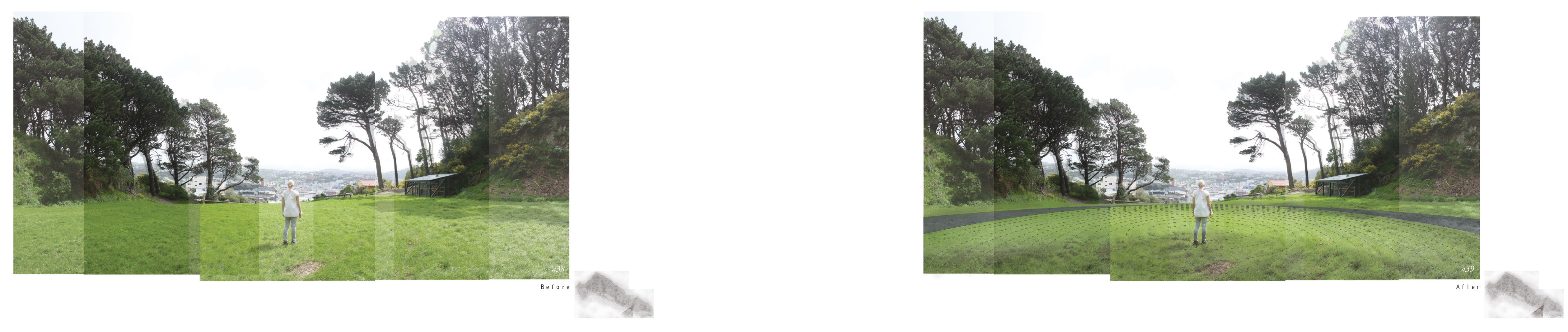

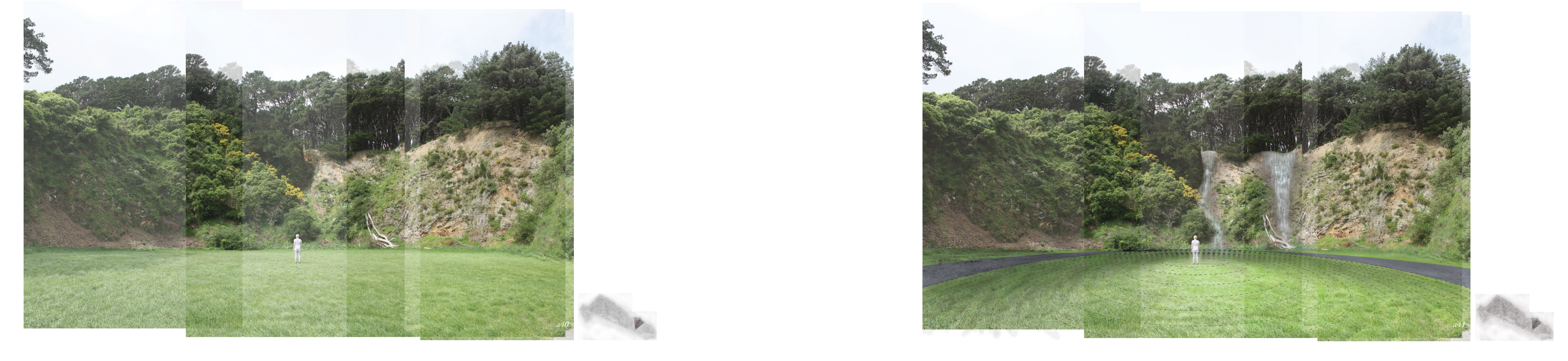


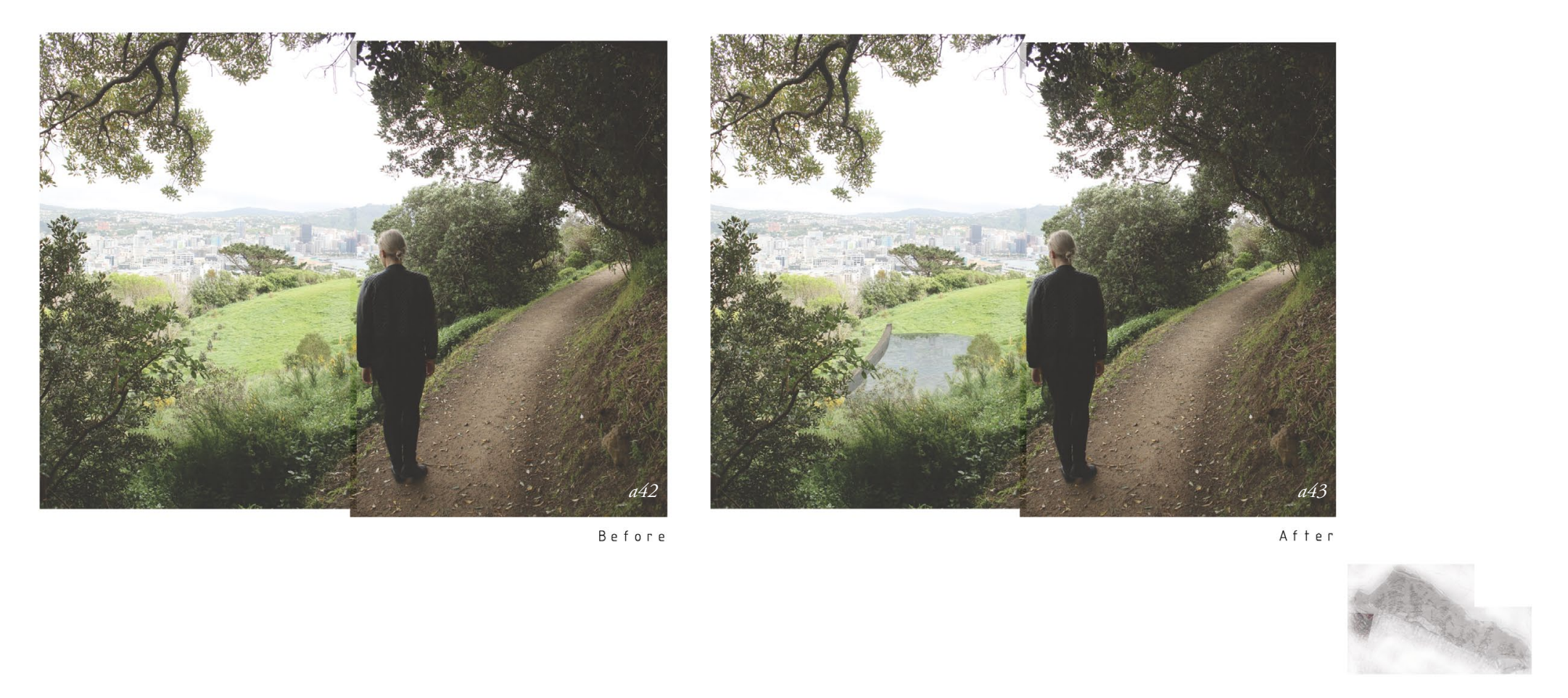




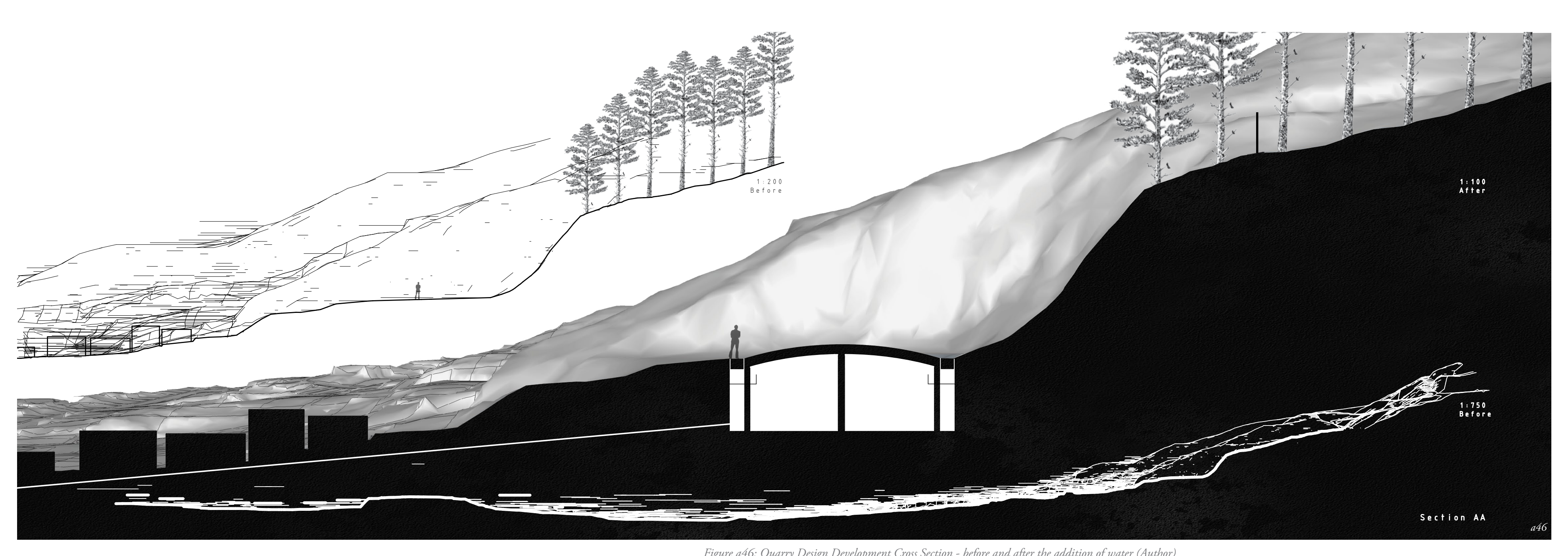




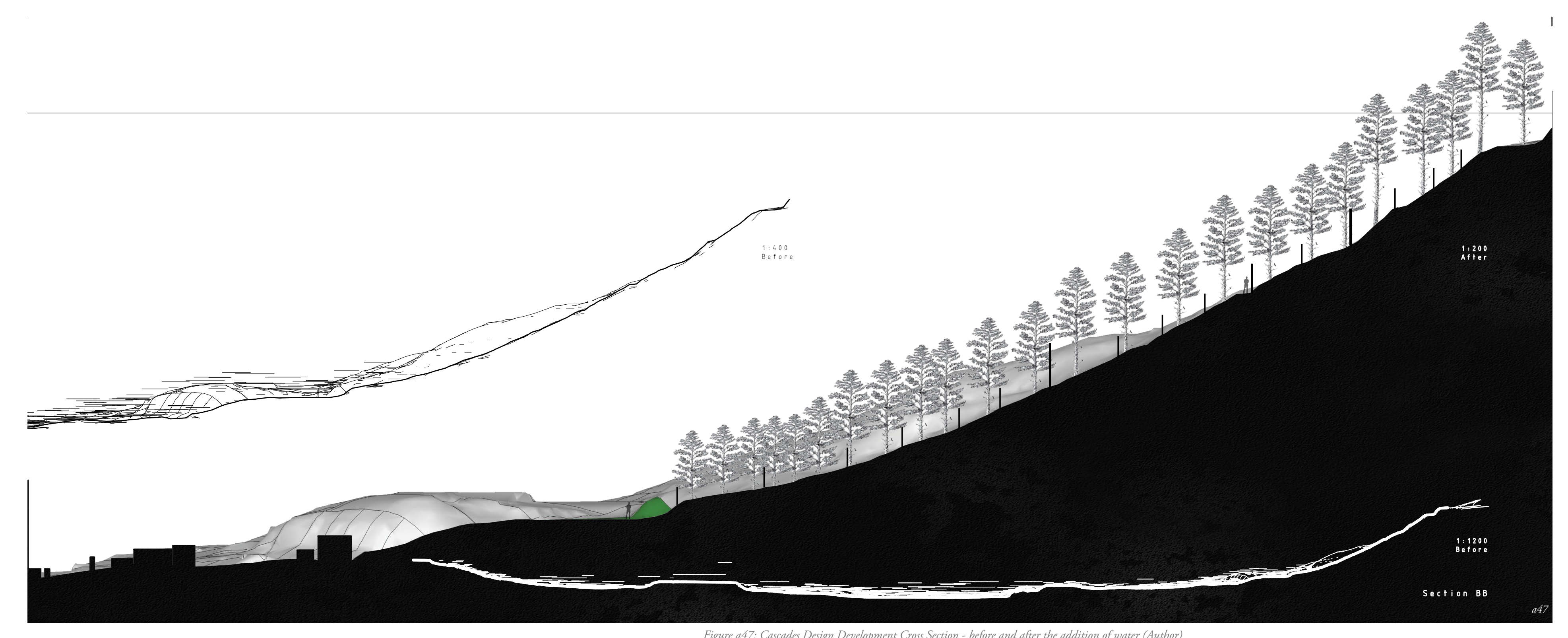


8.3 Engineering Calculations

Peak flow for a catchment for the critical rainfall event. ${ }^{I}$

Rational method

$\mathrm{Q}=\mathrm{CiA} / 360$

$\mathrm{Q}=$ peak discharge $\left(\mathrm{m}^{3 / s}\right)$

$\mathrm{C}=$ runoff coefficient

$\mathrm{i}=$ rainfall intensity $(\mathrm{mm} / \mathrm{hour})$ [found by analysing time of concentration]

A $=$ area of catchment (hectares)

Newtown Catchment - Area $(A)=442$ ha, runoff coefficient $(C)=0.64$, time of concentration $(T c)=75$ minutes. Newtown Catchment Management Plan (1997)

Using the current rainfall values in the Regional Standard, for duration 60 minutes (closest to 75 minute time of concentration) the in 50 year rainfall intensity $(\mathrm{i})=38.1 \mathrm{~mm} / \mathrm{hr}$.

$\mathrm{Q}=\mathrm{CiA} / 360=[0.64 \times 38.1 \times 442] / 360=29.9 \mathrm{~m} 3 / \mathrm{s}$.

(NIWA Tahihoro Nulurangi; Minisisty for hhe Environment; Capacity Infastructure 19) 
